\title{
The composition and structure of macrofungus communities in boreal upland type forests and peatlands in North Karelia, Finland
}

\author{
KAUKO SALO
}

SALO, K. 1993: The composition and structure of macrofungus communities in boreal upland type forests and peatlands in North Karelia, Finland. — Karstenia 33:61-99. ISSN 0453-3402

\begin{abstract}
As part of the 7th Finnish National Forest Inventory (7NFI), a network of permanent sample plots was established in North Karelia, Finland in 1980. All basidiocarps of macrofungi on each sample plot, 100 sq.m in size, were collected, counted, weighed and identified in 1981-1984. The sample plots represent nutrient-poor mineral soil and peatland site types with Scots pine (Pinus sylvestris) and Norway spruce (Picea abies) (sometimes with downy birch, Betula pubescens, on mesic mineral soils and mires) as the dominant tree species. The mires include virgin, recently drained, transitional and old peatland drainage sites. The commercial forests have undergone intensive logging (clear felling and thinning) in the past few years, and some mires have been ditched and fertilized.
\end{abstract}

Altogether 316 species of fungi were determined: 232 species of macrofungi (Polyporales, Boletales, Agaricales, Russulales) representing 61 genera, $73.4 \%$ of all mycoflora; 49 species, representing 34 genera, of Aphyllophorales (15.5\%); and other fungi incl. Ascomycotina, 35 species (11.1\%), representing 26 genera. The richest genera among the macrofungus species were Cortinarius (27 species), Mycena (19), Russula (16), Lactarius (15), Tricholoma (10), Hygrophorus (9) and Collybia (9). The 316 species of fungi that were identified were classified into three main ecological groups: mycorrhizal species according to their host tree species; saprophytic species (eight fertility groups according to what they usually acted upon); and parasites. Mesic forest site types had more versatile composition of mycorrhizal and saprophytic macrofungus species than did dryish and dry forest site types. Mycorrhizal macrofungus species accounted for more than $40 \%$ of all macrofungi in mineral soil forest and peatland site types. Drained peatland site types (especially pine bogs) had more macrofungus species than did virgin mires. TWINSPAN classification and DCA ordination were suitable in analysing the data on the macrofungi. The diversity of the macrofungi in mineral soil forest and peatland site types is discussed.

Key words: Basidiomycotina, Ascomycotina, macrofungus community, ecological group, mycorrhizal and saprophytic fungus, composition, structure, diversity, ordination, classification, boreal upland type forest, peatland, Finland

Kauko Salo, The Finnish Forest Research Institute, Joensuu Research Station, Yliopistokatu 7, FIN-80100 Joensuu, Finland.

\section{Contents}

Introduction 62

Material and methods 64

Study area and sample plot network

Measurements and observations

Mycoflora and ecological groups .......................... 67

Ordination and classification of sample plots

on the basis of macrofungi .....

Mineral soil forest site types 


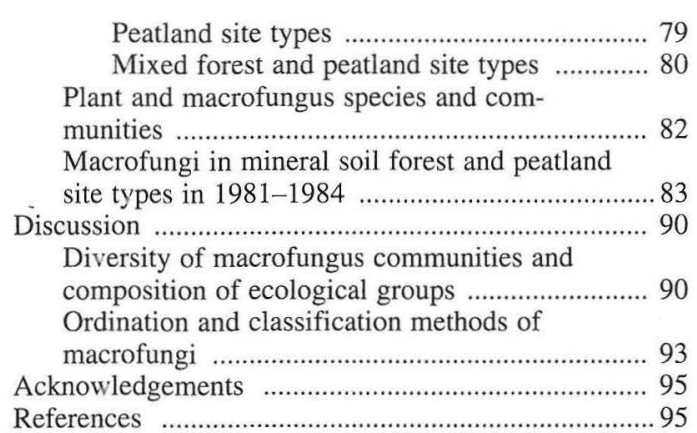

\section{Symbols}

Forest site types in the middle boreal vegetation zone:

ECT Empetrum-Calluna Type

EVT Empetrum-Vaccinium Type

VMT Vaccinium-Myrtillus Type

DeMT Deschampsia-Myrtillus Type

GOMT Geranium-Oxalis-Myrtillus Type

Development classes of tree stands:

$0 \quad$ Treeless site

1 Open area or seed tree stand

2 Small seedling stand

3 Advanced seedling stand

$4 \quad$ Young thinning stand

5 Advanced thinning stand

$6 \quad$ Mature stand

7 Shelterwood stand

Tree species:

$\begin{array}{ll}0 & \text { Treeless site } \\ 1 & \text { Scots pine (Pinus sylvestris) } \\ 2 & \text { Norway spruce (Picea abies) } \\ 3 & \text { Silver birch (Betula pendula) } \\ 4 & \text { Downy birch (Betula pubescens) } \\ 5 & \text { Aspen (Populus tremula) } \\ 6 & \text { Grey alder (Alnus incana) } \\ 7 & \text { Common alder (Alnus glutinosa) } \\ 8 & \text { Rowan (Sorbus aucuparia) } \\ 9 & \text { Goat willow (Salix caprea) }\end{array}$

Peatland site types:

RhK Herb-rich hardwood-spruce mire

$\mathrm{KgK}$ Oligo-mesotrophic paludified spruce forest

MK Vaccinium myrtillus spruce mire

VSR True tall sedge pine mire

PK Vaccinium vitis-idaea spruce mire

KR Spruce-pine mire

PsR Carex globularis pine mire

IR True dwarf shrub pine bog

TR Eriophorum vaginatum pine bog

RaR Sphagnum fuscum pine bog

LkN Ombrotrophic small sedge bog

Fertility classes of site types applied in Huikari's system (e.g. Huikari 1974):

II Rich forest types, herb-rich mires

III Mesic forest types, tall-sedge and

\begin{tabular}{|c|c|}
\hline & Vaccinium myrtillus-rich mires \\
\hline IV & $\begin{array}{l}\text { Dryish forest types, small-sedge and } \\
\text { Vaccinium vitis-idaea-rich mires }\end{array}$ \\
\hline V & $\begin{array}{l}\text { Dry forest types, cottongrass and dwarf shrub- } \\
\text { rich bogs }\end{array}$ \\
\hline VI & $\begin{array}{l}\text { Barren forest types, ombrotrophic } \\
\text { Sphagnum fuscum rich bogs }\end{array}$ \\
\hline
\end{tabular}

Drainage stages:

lt Natural stage

oj Recently drained peatland

$\mathrm{mu} \quad$ Transitional drained peatland

tkg Old peatland forest

\section{Introduction}

Compared to research carried out in the field of phytosociology, mycosociology (the study of communities of fungi) is a branch of science that has not been practised very much in Finland or elsewhere. This lack of research is explained by the complexity of mycocommunities, the great number of species in them, the dynamics of and seasonal variation in the production of their fruit bodies, the life cycle of ectomycorrhizal fungi and the lack of systematic sample plot networks.

At present, fungal studies have concentrated mainly on the production of fruit body, structures which constitute merely one stage in the life cycle of the fungi. The presence of fruit bodies is an indication of only one aspect of the ecology of a particular species.

Several studies dealing with yields of fungi and their species composition include results pertaining to fundamental issues associated with fungal communities and mycoecology in mineral soil forest sites: Haas (1932), Friedrich (1936, 1937) and Leischner-Siska (1939) in Germany; Wilkins \& Harris (1946) in Britain; Lisiewska (1965, 1974, 1978), Gumińska (1966) and Holownia (1978) in Poland; Darimont (1973) in Belgium; Barkman (1976) in the Netherlands; Tortić \& Lisiewska (1978) in Croatia; and De Dominicis \& Barluzzi (1983) in Italy.

Working in Austria Höfler (1937) carried out one of the first methodological fungal studies in beech forests. He counted the number of fruit bodies and then determined their fresh weight. Höfler contended that fungi can be regarded as one component of a plant association alongside vascular plants and mosses, or that associations of fungi could be considered as sociological units of their own. Kalamees (1968, 1971, 1979, 1980a, 1980b), in Estonia, studied methodologyrelated problems of fungal communities, the 
taxonomy of fungi, their occurrence during the different seasons of the year and ecological groups of macrofungi.

The yield study done by Petrenko (1978) also dealt with the structure of fungal communities. This work represents the first true mycosociological study in Russia. In the former Czechoslovakia, Fellner (1987, 1988a) investigated the problems associated with the classification of fungal communities

Mycosociological examination of fungi inhabiting mires was conducted by Lange (1948), in Denmark, who studied the occurrence of fungi as members of the plant community. Favre (1948) did research on fungi in bogs in the alpine and sub-alpine zone of the Jura Mountains in Switzerland. Since that times the fungal communities of various mires have been studied in many countries in Europe; examples include the works of Kreisel (1954), Kotlaba \& Kubìč ka (1960), Veijalainen (1974), Einhellinger (1976, 1977, 1982), Salo (1979), Kalamees (1982), Kalamees \& Raitviir (1982), Saari \& Salonen (1983), Heimala-Raimas (1986) and Salonen \& Saari (1990).

The first ecological study on fungi to be done in Finland was conducted in 1892-1894 and dealt with the larger fungi in the Vyborg region (Thesleff 1920), which now belongs to Russia. The yields of larger fungi on the mineral soil sites of southern and central Finland were studied, e.g. by Rautavaara (1947), Sjöblom et al. (1979), Vauras \& Huhtinen (1980) and Hintikka (1988), the yields of larger fungi in northern Finland being studied, e.g. by Metsänheimo (1982, 1987), Herva \& Norokorpi (1983), Ohenoja \& Koistinen (1984) and Ohenoja (1993).

In Sweden Kardell et al. (1980) conducted a yield study of fungi in connection with a national forest inventory. Since then, several studies have been conducted in Sweden on the impacts of silvicultural measures on fungal yields (Wästerlund \& Ingelög 1981, Kardell 1984, Kardell \& Eriksson 1987).

In Norway, attention began to focus on mycosociology in the late 1970s and early 1980s (Gulden 1982), as shown by the ecological and sociological theses completed at the University of Oslo (Østmoe 1979, Kristoffersen 1981, Markussen 1982). Mehus (1986) studied the relationships between forest types and fungus flora.
The increasing application of computerised methods in connection with sociological studies that occurred in the 1980s introduced more quantitative aspects into the study of fungi. Arnolds (1981) and Jansen (1981) did research on the mycoecology and mycosociology of heaths and oak forests in the Netherlands. Later, Jansen \& De Nie (1988) investigated the relationship between mycorrhizae and the fruit bodies of fungi in plantations of Douglas fir. In North America, the yields of mycorrhizal and saprophytic fungi in coniferous forests have been studied by several researchers, such as Vogt et al. (1980, 1981), Bills et al. (1986), and Villeneuve et al. (1989).

The pollution and decline of vast forest areas that was first observed in Central Europe in the mid1980s also caught the attention of mycologists. It was observed that many ectomycorrhizal fungi had vanished from polluted areas over a span of just a few years. Damage was observed to have taken place in the fine roots and mycorrhizae (Hartig's net) of conifers, and it was generally thought that acid rain was responsible for the disappearance of the fungi (e.g. Meyer 1987, Blaschke 1988). The changes that have occurred in the chemistry of the soil have been the subject of intensive research during the past few years (e.g. Nilsson \& Bergkvist 1983, Tyler 1985, Dighton \& Skeffington 1987, Jansen 1988, van Breemen \& van Dijk 1988, Dighton \& Harrison 1990, Jansen \& Dighton 1990). Field trials conducted in Germany by Winterhoff (1984), in the Netherlands by Arnolds $(1985,1988,1991)$ and by Jansen \& van Dobben (1987) have all observed a drop in the number of fruit bodies. In the former Czechoslovakia, Fellner (1988b, 1989) considered mycorrhizal fungi to be useful bioindicators of polluted air.

Studies dealing with the structure of plant communities have put multivariable methods to widespread use for the past fifteen years or so (Økland 1990). Finnish studies investigating the structure of fungal communities have applied ordination and classification methods to some extent (Jäppinen et al. 1986). Hansen (1988, 1989) used the principal component analysis method and discriminant analysis when studying the occurrence of macrofungi in beech forests in Sweden. The structure of fungal populations and fungal communities on mineral soil forest sites has been studied in Sweden by Dahlberg \& 
Stenlid (1990), Dahlberg (1991) and Dahlberg \& Stenström (1991). In Canada, Nantel \& Neumann (1992) used two canonical correspondence analyses and principal coordinates analysis to clarify the structure of tree and ectomycorrhizalbasidiomycete communities.

The purposes of this project were (1) to clarify the species composition of mycorrhizal and saprophytic fungi, and the structure of macrofungus communities in commercially logged forests of different ages on mineral soil sites and (2) to compare the species composition of the macrofungi of drained peatlands to those of virgin peatland sites. A further aim was (3) to test the applicability of community ecology methods in the grouping of sample plots and in classifying macrofungi.

\section{Material and methods}

\section{Study area and sample plot network}

The study area is situated within the middle boreal forest vegetation zone and the southern part of the Pohjanmaa fen region; i.e. in the transition area between the southern and middle boreal coniferous zones (Ahti et al. 1968, Kalliola 1973) (Fig. 1).

The study area is characterised by nutrient-poor mineral soil and peatland site types, the dominant tree species being Scots pine (Pinus sylvestris) and Norway spruce (Picea abies), and sometimes downy birch (Betula pubescens) on mesic mineral soil sites. Acidic podsol is the mineral soil type occurring in the area. The mires include both virgin and drained sites. The mineral soil forests of the region have been subjected to intensive logging (clear felling and thinning) in the past few years. Mires in the region have been ditched and fertilized.

The area has a mean elevation above sea level of 175 $\mathrm{m}$ in the southern parts, $190 \mathrm{~m}$ in the central parts and 200$220 \mathrm{~m}$ in the northern parts. The effective temperature sum $\left(>5^{\circ} \mathrm{C}\right.$ ) of the area during the growing season is c. 1000 d.d. (Sevola 1983). The average duration of the growing season $\left(<5^{\circ} \mathrm{C}\right)$ in the study area ranges from 145 to 150 days and the precipitation for the growing season is c. $300 \mathrm{~mm}$, while the annual rainfall ranges between 550 and $600 \mathrm{~mm}$ (Kolkki 1966). The underlying bedrock in the study area consists mainly of granitic gneiss with small amounts of veined gneiss and granite (Pohjois-Karjalan luonnonympäristö 1974).

As part of the 7th Finnish National Forest Inventory (7NFI), a network of permanent all-purpose sample plots was established during the summer of 1980 , in the area covered by the Nurmes Plan (Sevola 1983) within the Nurmes and Lieksa districts of the Forest and Park Service (Fig. 2). The area covered by the Nurmes Plan as well as the Lieksa district, serving as a control area, have a sample plot network that is denser than normal and within which the inventory blocks are located at intervals of $4 \mathrm{~km}$ instead of $8 \mathrm{~km}$ (Fig. 2). As a systematic sample, three permanent sample plots were marked out in each block of the field to be inventoried (Fig. 3). The figures include 54 additional sample plots examined in 1983 (stump and growing stock sample plots) and located $200 \mathrm{~m}$ away from the permanent sample plots (Fig. 3).

The distribution of the sample plots inventoried in 1981-1984 according to forest and peatland site types is shown in Table 1. Three main stages were distinguished in the successional development of peatlands: recently drained sites, transitional sites, and old peatland drainage sites (Sarasto 1957, 1961). These stages are included in the main classes of peatlands, while peatlands in their natural state are shown in parentheses (Table 1). Mixed forest and

Table 1. Numbers of sample plots representing various types of forest and peatland sites in the middle boreal vegetation zone (Pohjanmaa-Kainuu) in 1981-1984. Natural peatland site types in parentheses.

\begin{tabular}{|c|c|c|c|c|c|c|c|c|c|}
\hline Year & GOMT & $\begin{array}{l}\text { VMT } \\
\text { DeMT }\end{array}$ & EVT & ECT & $\begin{array}{l}\text { Spruce } \\
\text { mires }\end{array}$ & $\begin{array}{l}\text { Pine } \\
\text { mires and } \\
\text { bogs }\end{array}$ & $\begin{array}{l}\text { Treeless } \\
\text { bogs and } \\
\text { fens }\end{array}$ & $\begin{array}{l}\text { Mixed forest } \\
\text { and peatland } \\
\text { site types }\end{array}$ & Total \\
\hline 1981 & 2 & 13 & 9 & 10 & $9(4)$ & $17(6)$ & $1(1)$ & 18 & 79 \\
\hline 1982 & & 24 & 33 & 12 & $8(4)$ & $44(7)$ & $1(1)$ & 14 & 136 \\
\hline 1983 & & 38 & 50 & 12 & $18(7)$ & $44(6)$ & $8(5)$ & 22 & 192 \\
\hline 1984 & & 36 & 51 & 13 & $15(5)$ & $44(6)$ & $6(3)$ & 24 & 189 \\
\hline Total & 2 & 111 & 143 & 47 & $50(20)$ & $149(25)$ & $16(10)$ & 78 & 596 \\
\hline
\end{tabular}

GOMT Geranium-Oxalis-Myrtillus Type

VMT Vaccinium-Myrtillus Type

DeMT Deschampsia-Myrtillus Type

EVT Empetrum-Vaccinium Type

ECT Empetrum-Calluna Type 
peatland site types have been placed into a category of their own, and they were also treated separately in the statistical processing of the material. The relative proportions of mixed forest and peatland types were determined visually. Vegetation cover analyses were employed as a means of ensuring the correctness of mixed forest and peatland type classifications.

With regard to sample plots located on forested land (forest land, scrub land, waste land), dryish (EVT) and mesic (VMT, DeMT) mineral soil forest types were well represented. Dry (ECT) and rich mineral soil sites (GOMT) were relatively rare (Table 1). Common peatland types included Vaccinium myrtillus spruce mires, true dwarf shrub pine bogs, Eriophorum vaginatum pine bogs, and Carex globularis pine mires and drained areas of the same, of various ages. Bogs characterised by Sphagnum fuscum, herbs and eutrophic fens were relatively rare.

\section{Measurements and observations}

When the permanent sample plots were established in 1980 , the NFI crew recorded the parameters on the stand and the growing stock. Biologists made botanical assessments of the forest, peatland classifications, descriptions of vegetation cover, estimates of canopy cover, and berry and mushroom yield studies. The forest and peatland flora of the study area and the classification of the site types have been treated elsewhere by Hotanen \& Nousiainen (1990).

Of the parameters on the growing stock recorded by the NFI crew, the following were used in this study: development class, dominant tree species, and other tree species present. In the field mineral soil sites were classified into the various site types (Lehto \& Leikola 1987) and peatlands into mire, bog and fen types (Heikurainen \& Pakarinen 1982, Huikari et al. 1964, 1974, Heikurainen 1986). Drained sites were also assessed for their drainage stage (recently drained, transitional, old drainage site) as described by Sarasto (1961). Regressive Polytrichum commune and P. strictum transitional sites were coded in this connection as being transitional drainage sites of the particular peatland type, without separating them into groups of their own.

The vegetation cover of species present in the field and ground layers were estimated from eight squares, each 1 $\mathrm{m}^{2}$ in size, using a scale of $+, 0.5,1,2,3,5,7,10,12,15$, $20,25 \ldots 85,90,93,95,97,98,99,100$. Eight plant squares were systematically placed in the corners and in the middle of the sides of the mycoflora sample plot (Fig. 4).

In this study, the macrofungi include four orders: Polyporales, Boletales, Agaricales and Russulales. In addition to the macrofungi collected from the sample plots during 1981-1984, certain other fungi readily visible to the naked eye were also identified: Aphyllophorales, Heterobasidiomycetes, Gasteromycetes and Ascomycotina (Table 2).

The fungi were inventoried three times during the growing seasons of 1981 (79 sample plots) and 1982 (136) and twice (192 sample plots) in 1983. In 1984, the sample plots (189) were inventoried once. The total number of

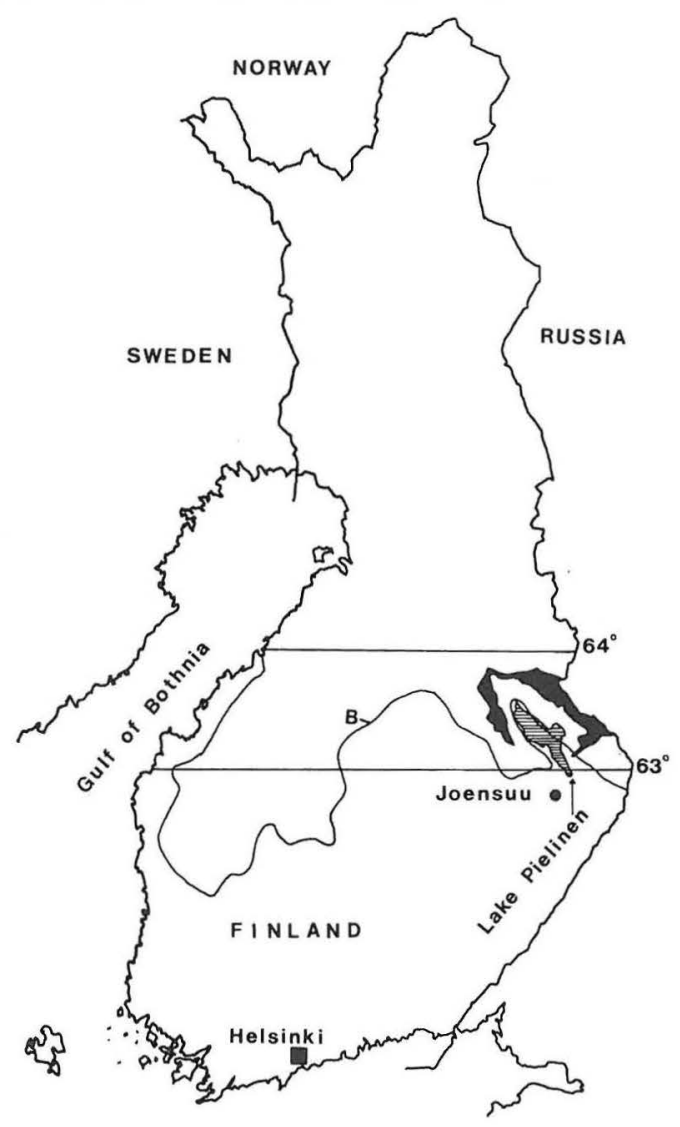

Fig. 1. Location of the study area (darkened). $\mathrm{B}=$ border between southern and middle boreal vegetation zones (Ahti et al. 1968).

different sample plots visited was 596 (Table 1). Multivariable methods were used to analyse the macrofungal material collected in 1981 .

The mycoflora sample plots were $0.01(10 \times 10 \mathrm{~m})$ ha in size (Fig. 4). All basidiocarps of fungi found in the sample plots were collected, the numbers per species were tallied and their fresh weights were measured. A study concerning mushroom yields will be presented at a later date. All unidentified species were subjected to microscopic examination. The specimens are archived at $\mathrm{H}, \mathrm{JOE}$ and OULU.

The following taxonomy and nomenclature were applied: Hämet-Ahti et al. (1986) for the vascular plants; Koponen et al. (1977) for mosses; and Ahti (1981) for lichens. The fleshy fungi largely follows that of Hansen \& Knudsen (1992). The orders Aphyllophorales, 


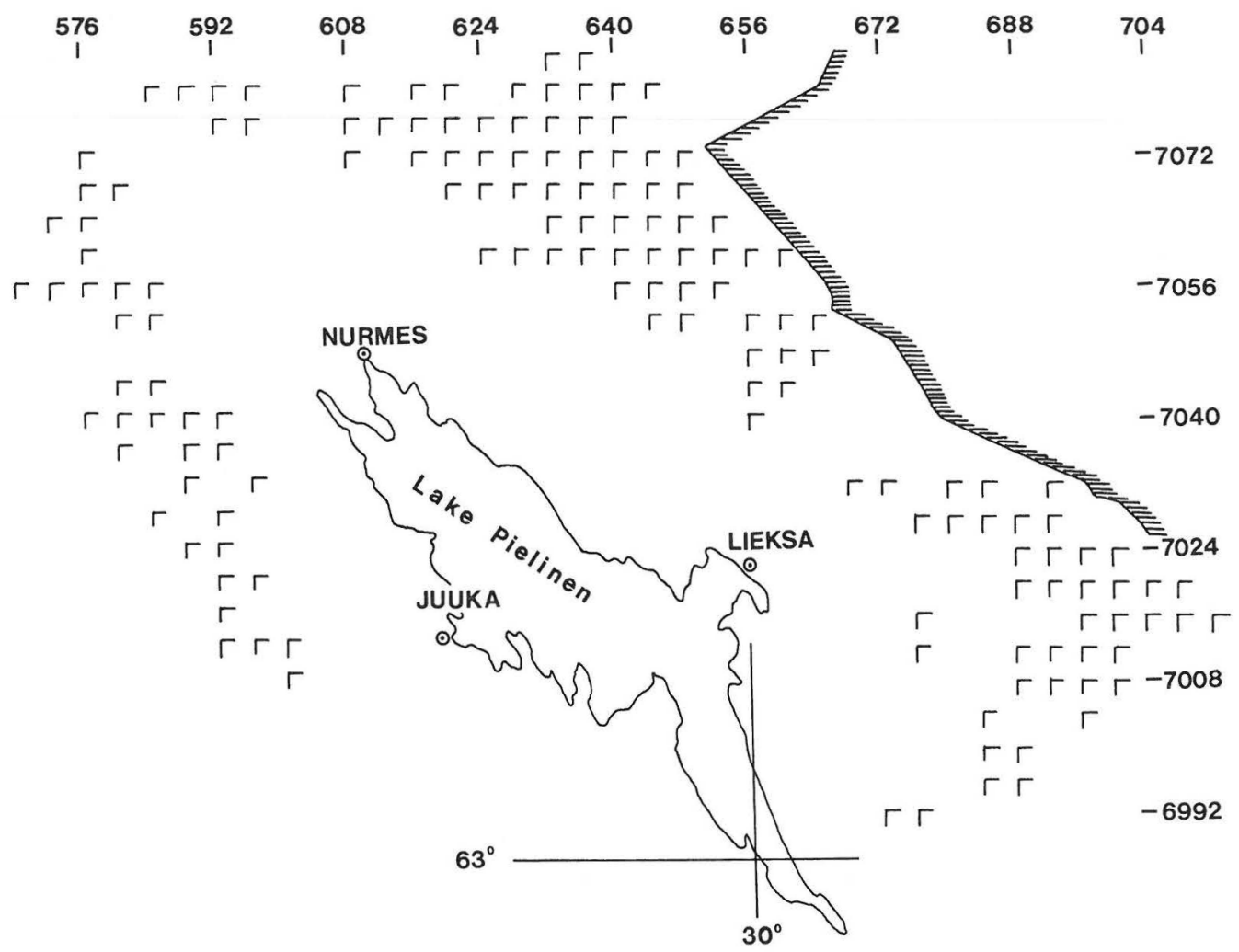

Fig. 2. Location of the inventory tracts and basic map (1:20 000) coordinates.

Heterobasidiomycetes and Gasteromycetes are treated in accordance with Jülich (1984) and Niemelä (1988). Ascomycetes according to Dennis (1978) and Breitenbach \& Kränzlin (1981).

Table 2. The occurrence of various fungal groups in the sample plots studied.

\section{Basidiomycotina}

293

Polyporales, Boletales,

Agaricales, Russulales

Aphyllophorales

Heterobasidiomycetes

Gasteromycetes

Ascomycotina

Discomycetes

Pyrenomycetes

Plectomycetes

Total

\section{Numerical analysis}

The measurement data collected from the sample plots were merged to form a file in which the record types were arranged in ascending order on the basis of the sample plot coordinates $(y, x)$ and the number of the sample plot. The mean coverages of the plant species, expressed in percentages, were output for the forest and peatland sample plots and the mixed sites. TWINSPAN classification (Hill 1979a) and DCA ordination (Hill \& Gauch 1980) were used in analysing the data on the macrofungi. The CONDENSE and DATAEDIT (Singer 1980) programs were used to process the data on the macrofungi. The data were grouped, according to the species of macrofungi as mycorrhizal fungi and saprophytic fungi. All species of Aphyllophorales, Heterobasidiomycetes, Gasteromycetes and Ascomycotina encountered on the sample plots were deleted from the data during the course of analysis.

Saprophytic fungi acting upon the dung of many herbivores can flourish on all forest and peatland site types visited by elk and hares. Mycorrhizal fungi specific to a single tree species (e.g. Scots pine) occur only on such forest and peatland types where this particular tree species 
grows. Interpretations concerning the occurrence of mycorrhizal fungi are made difficult by fungi which can form mycorrhiza with more than one tree species. In this connection, the downweighting option of DCA was used to reduce the effect of rare species (Hill 1979b). Prior to the DCA analysis (under DATAEDIT), the fungus material was subjected to a logarithmic transformation serving to reduce the significance of fungus species with high biomasses. By observing the cluster of points (mycoflora sample plots) obtained in the ordination, conclusions were drawn as to the species of macrofungi on forest and peatland site types and also as to the grouping of the mycoflora sample plots in relation to one another.

In this study the variable used in connection with the TWINSPAN classification was the biomass of the macrofungus species (g/a), which was applied so that the abundance threshold values for indicator species were (on a logarithmic scale): 0, 0.3, 0.8, 1.2 and $2 \mathrm{~g}$. In accordance with these threshold values, the biomasses were determined respectively as follows: $1=0.100-1.00 \mathrm{~g}, 2=$ $2.00-6.29 \mathrm{~g}, 3=6.30-15.89 \mathrm{~g}, 4=15.90-99.99 \mathrm{~g}$ and $5=$ more than $100.00 \mathrm{~g}$. The TWINSPAN printouts for the forest and peatland site types and the mixed sample plots were drawn only up to the second divisional level; further divisional levels were impractical because the insufficiency of sample plots would have led to splitting of the material into units too small from the point of view of both interpretation and methodology.

\section{Results}

\section{Mycoflora and ecological groups}

During the period of 1981 to 1984 , the following identifications were carried out: 316 species and groups of mycoflora; 232 species of macrofungi (Polyporales, Boletales, Agaricales, Russulales), representing 61 genera, $73.4 \%$ of all mycoflora; 49 species, representing 34 genera, of Aphyllophorales (15.5\%) and other fungi incl. Ascomycotina, 35 species (11.1\%), 26 genera (Table 3).

The richest genera among the macrofungus species were Cortinarius (27 species), Mycena (19), Russula (16), Lactarius (15), Tricholoma (10), Hygrophorus (9) and Collybia (9) (Table 3). Some genera containing unknown near-species were also identified in the cource of this study. Cortinarius spp. describes the group which includes nearspecies in the subgenera Telamonia.

The 316 species of fungi which were identified were placed into three main ecological groups: mycorrhizal species according to their host tree species; saprophytic species (eight fertility groups according to what they usually acted upon); and parasites (Table 4). The fertility groups of some mycorrhizal and saprophytic species were basis

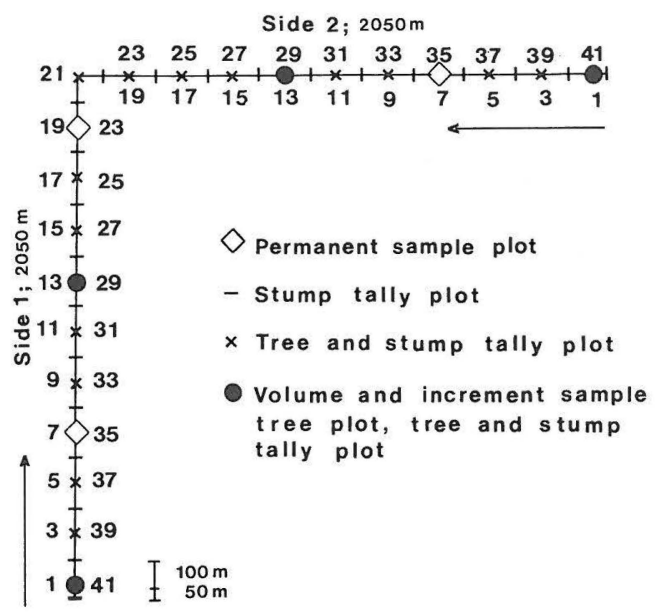

Fig. 3. Layout of a tract.

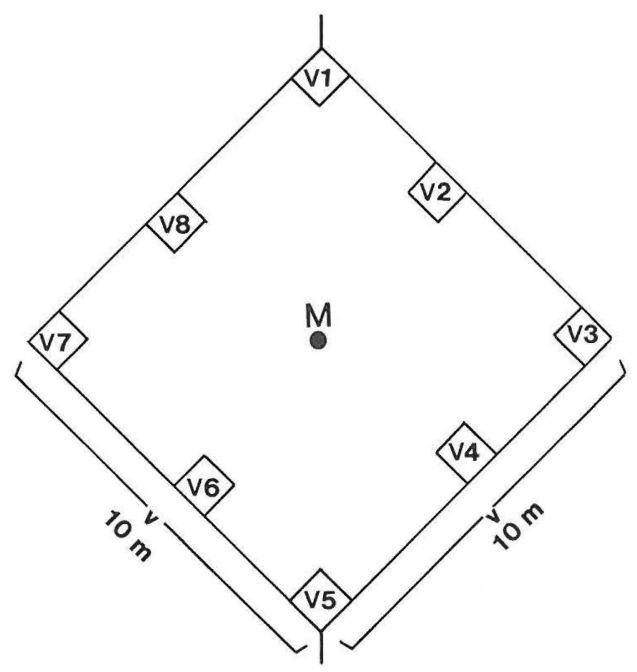

Fig. 4. Mycoflora sample plot (M) (100 sq.m) and location of vegetation sample plots (V) $(8 \times 1$ sq.m).

of the determined the literature (Trappe 1962, Hacskaylo 1965, Hintikka \& Näykki 1967, Maas Geesteranus 1975, Brown \& Sinclair 1981, Strid 1982 and Heiskanen \& Ohenoja 1986). The composition of mycorrhizal species, wood, litter and other saprophytes is given in Tables $5-8$. 
Table 3. Mycoflora in boreal upland type forests and peatlands in North Karelia, Finland, 1981-1984.

\section{BASIDIOMYCOTINA}

I HYMENOMYCETES

1. Polyporales, Boletales, Agaricales, Russulales

1. Lentinus conchatus (Bull.: Fr.) Schroet.

2. L. lepideus (Fr.: Fr.) Fr.

3. Pleurotus pulmonarius (Fr.) Quél.

4. Polyporus brumalis (Pers.: Fr.) Fr.

5. P. ciliatus Fr.: Fr.

6. P. varius (Pers.) Fr.

7. Hygrophoropsis aurantiaca (Wulf.: Fr) Schroet.

8. H. olida (Quél.) Métr.

9. Paxillus involutus (Batsch : Fr.) Fr.

10. P. atrotomentosus (Batsch : Fr.) Fr.

11. Boletus edulis Bull.: Fr.

12. B. pinophilus Pilát \& Dermek

13. B. subtomentosus L.: Fr.

14. Chalciporus piperatus (Bull.: Fr.) Bat.

15. Leccinum vulpinum Watl.

16. L. aurantiacum (Bull.) S. F. Gray

17. L. versipelle (Fr.) Snell

18. L. niveum (Fr.) Rauschert

19. L. scabrum (Bull.: Fr.) S. F. Gray

20.

21.

22.

23.

24.

25.

26.

27.

28.

29.

30.

31.

32.

33.

34.

35.

36.

37.

38.

39.

40.

41.

42.

43.

44.

45.

46.

47.

48.

49.

50.

51.

\section{L. variicolor Watl.}

Chroogomphus rutilus (Schaeff.: Fr.) O. K. Miller

Gomphidius roseus (Fr.) Fr.

G. glutinosus (Schaeff.: Fr.) Fr.

Suillus flavidus (Fr.: Fr.) J. S. Presl

S. luteus (L.: Fr.) Roussel

S. bovinus (L.: Fr.) Roussel

S. variegatus (Sw.: Fr.) O. Kuntze

Tylopilus felleus (Bull.: Fr.) Karst.

Hygrophorus karstenii Sacc. \& Cub.

$H$. piceae Kühn.

H. olivaceoalbus (Fr.: Fr.) Fr.

H. korhonenii Harmaja

$H$. agathosmus (Fr.) Fr.

H. pustulatus (Pers.: Fr.) Fr.

H. camarophyllus (Alb. \& Schw.: Fr.)

Dumèe, Grandjean \& Maire

H. hypothejus (Fr.: Fr.) Fr.

Hygrophorus sp.

Armillaria borealis Marxmüller \& $\mathrm{K}$.

Korhonen

Baeospora myosura (Fr.: Fr.) Sing.

Cantharellula umbonata (Gmel.: Fr.) Sing.

Clitocybe gibba (Pers.: Fr.) Kumm.

C. candicans (Pers.: Fr.) Kumm.

C. clavipes (Pers.: Fr.) Kumm.

C. fragrans (With.: Fr.) Kumm.

C. diatreta (Fr.: Fr.) Kumm.

C. ditopus (Fr.: Fr.) Gill.

C. vibecina (Fr.) Quél. ss. lat.

Clitocybe spp.

Collybia confluens (Pers.: Fr.) Kumm.

C. acervata (Fr.) Kumm.

C. putilla (Fr.: Fr.) Sing.
52.

53.

54.

55.

56.

57.

58.

59.

60.

61.

62.

63.

64.

65.

66.

67.

68.

69.

70.

71.

72.

73.

74.

75.

\section{6.}

77.

78.

79.

80.

81.

82.

\section{3.}

84.

85.

86.

87.

88.

89.

90.

91.

92.

93.

94.

95.

96.

97.

98.

99.

100.

101.

102.

103.

104.

105.

106.
C. maculata (Alb. \& Schw.: Fr.) Kumm.

C. butyracea (Bull.: Fr.) Kumm.

C. cirrata (Pers.) Kumm.

C. tuberosa (Bull.: Fr.) Kumm.

C. dryophila (Bull.: Fr.) Kumm.

C. succinea (Fr.) Quél.

Cyphellostereum laeve (Fr.) Reid

Cystoderma carcharias (Pers.) Konr. \& Maubl.

C. amianthinum (Scop.) Konr. \& Maubl.

C. granulosum (Batsch : Fr.) Kühn.

Fayodia maura (Fr.) Sing.

Flammulina velutipes (Curt.: Fr.) Sing.

Hohenbuehelia petalodes (Bull.: Fr.) Schulz.

Laccaria bicolor (Maire) Orton

L. proxima (Boud.) Pat.

L. laccata (Scop.: Fr.) Berk. \& Br.

Lyophyllum fumosum (Pers.: Fr.) Orton

L. palustre (Peck) Sing.

Lyophyllum sp.

Marasmius epiphyllus (Pers.:Fr.) Fr.

$M$. androsaceus (L.: Fr.) Fr.

Megacollybia platyphylla (Pers.: Fr.) Kotl.

\& Pouz.

Melanoleuca sp.

Micromphale perforans (Hoffm.: Fr.) S. F.

Gray

Mycena viscosa Maire

M. epipterygia (Scop.: Fr.) S. F. Gray

M. vulgaris (Pers.: Fr.) Kumm.

$M$. rorida (Fr.: Fr.) Quél.

M. clavicularis (Fr.) Gill.

M. galopus (Pers.: Fr.) Kumm.

M. sanguinolenta (Alb. \& Schw.: Fr.)

Kumm.

M. rosella (Fr.) Kumm.

M. rubromarginata (Fr.: Fr.) Kumm.

M. flavoalba (Fr.) Quél.

M. pura (Pers.: Fr.) Kumm.

M. cinerella Karst.

M. megaspora Kauffm.

M. galericulata (Scop.: Fr.) S. F. Gray

M. urania (Fr.: Fr.) Quél.

M. metata (Fr.) Kumm.

M. laevigata (Lasch : Fr.) Gill.

M. stipata Maas G. \& Schwöbel

Mycena sp.

Omphaliaster borealis (M. Lange \& Skifte)

Lamoure

Omphalina umbellifera (L.: Fr.) Quél.

O. philonotis (Lasch) Quél.

O. oniscus (Fr.: Fr.) Quél.

O. fibula (Bull.: Fr.) Quél.

Panellus mitis (Pers.: Fr.) Sing.

P. serotinus (Schrad.: Fr.) Kühn.

Strobilurus stephanocystis (Hora) Sing.

S. esculentus (Wulf.: Fr.) Sing.

Tricholoma inamoenum (Fr.: Fr.) Gill.

T. album (Fr.) Kumm.

T. nauseosum (Blytt) Kytövuori 
107. T. fulvum (DC.: Fr.) Sacc.

108. T. pessundatum (Fr.) Quél. non ss. Lange

109. T. aestuans (Fr.) Gill.

110. T. flavovirens (Pers.: Fr.) Lundell

111. T. portentosum (Fr.) Quél.

112. T. virgatum (Fr.: Fr.) Kumm.

113. Tricholoma sp.

114. Tricholomopsis rutilans (Schaeff.: Fr.) Sing.

115.

116.

117.

118.

119.

120.

121.

122.

123.

124.

125.

126.

127.

128.

129.

130.

131.

132.

133.

134

135.

136.

137.

138.

139.

140.

141.

142.

143.

144.

145.

146.

147.

148.

149.

150.

151.

152.

153.

154.

155.

156.

157.

158.

159.

160.

161.

162.

163.

164.

165.

T. decora (Fr.) Sing.

Xeromphalia campanella (Batsch : Fr.) Kühn. \& Maire

X. caulicinalis Kühn. \& Maire

$X$. fellea Maire \& Malenç.

Amanita porphyria (Alb. \& Schw.: Fr.)

Mlady

A. virosa (Fr.) Bertilloni

A. muscaria (L.: Fr.) Hook.

A. regalis (Fr.) Michael

A. vaginata (Bull.: Fr.) Vitt.

A. fulva (Schaeff.) Pers.

Pluteus atricapillus (Batsch) Fayod

Pluteus sp.

Lepiota clypeolaria (Bull.: Fr.) Kumm.

Coprinus cinereus (Schaeff.: Fr.) S. F. Gray

C. radiatus (Bolt.: Fr.) Pers.

Coprinus sp.

Psathyrella candolleana (Fr.: Fr.) Maire

Psathyrella sp.

Hypholoma fasciculare (Huds.: Fr.) Kumm.

H. capnoides (Fr.) Kumm.

H. lateritium (Schaeff.: Fr.) Schroet.

H. myosotis (Fr.) Moser

H. udum (Pers.: Fr.) Kühn.

H. elongatum (Pers.: Fr.) Rick.

Hypholoma sp.

Kuehneromyces mutabilis (Schaeff.: Fr.)

Sing. \& Smith

Pholiota flammans (Batsch : Fr.) Kumm.

P. mixta (Fr.) Sing.

P. alnicola (Fr.: Fr.) Sing.

P. scamba (Fr.: Fr.) Moser

Pholiota sp.

Psilocybe magnivelaris (Peck) Høiland

Psilocybe sp.

Stropharia semiglobata (Batsch : Fr.) Quél.

$S$. aeruginosa (Curt.: Fr.) Quél.

S. hornemannii (Fr.: Fr.) Lundell

Agrocybe sp.

Cortinarius cinnamomeus (L.: Fr.) Fr.

C. croceus (Schaeff.) Bigeard \& Guillemin

C. huronensis Ammirati \& Smith

C. sanguineus (Wulf.: Fr.) Fr.

C. semisanguineus (Fr.) Gill.

C. orellanoides Henry

C. bolaris (Pers.: Fr.) Fr.

C. gentilis (Fr.) Fr.

C. vibratilis (Fr.) Fr.

C. delibutus Fr.

C. trivialis Lange

C. muscigenus Peck

C. mucosus (Bull.: Fr.) Kickx

C. triumphans Fr.
166.

167.

168.

169.

170.

171.

172.

173.

174.

175.

176.

177.

178

179.

180.

181.

182.

183.

184.

185.

186.

187.

188.

189.

190.

191.

192.

193.

194.

195.

196.

197.

198.

199.

200.

201.

202.

203.

204.

205.

206.

207.

208.

209.

210.

211.

212.

213.

214.

215.

216.

217.

218.

219.

220.

221.

222.

223.
C. pholideus (Fr.: Fr.) Fr.

C. traganus Fr.: Fr.) Fr.

C. camphoratus (Fr.) Fr.

C. anomalus (Fr.: Fr.) Fr.

C. armillatus (Fr.: Fr.) Fr.

C. evernius (Fr.: Fr.) Fr.

C. brunneus (Pers.: Fr.) Fr.

C. laniger Fr.

C. obtusus (Fr.) Fr.

C. paleaceus Fr.

C. hemitrichus (Pers.: Fr.) Fr.

C. flexipes (Pers.: Fr.) ss. Kühn.

Cortinarius spp.

Galerina marginata (Batsch) Kühn.

G. paludosa (Fr.) Kühn.

G. tibiicystis coll. (Atk.) Kühn.

G. cf. sphagnorum (Pers.: Fr.) Kühn.

G. hypnorum ss. lat. (Schrank : Fr.) Kühn.

Galerina spp.

Gymnopilus penetrans (Fr.) Murr.

Hebeloma longicaudum (Pers.: Fr.) Kumm. ss. Lange

H. crustuliniforme (Bull.) Quél.

Hebeloma sp.

Inocybe lanuginosa (Bull.: Fr.) Kumm.

I. lacera (Fr.) Kumm.

Inocybe sp.

Naucoria sp.

Phaeocollybia sp.

Rozites caperatus (Pers.: Fr.) Karst.

Tubaria confragosa (Fr.) Kühn.

Entoloma nitidum (Quél.) Quél.

E. cetratum (Fr.: Fr.) Moser

Entoloma sp. 1. incl. E. nidorosum (Fr.)

Quél.

Entoloma sp. 2. incl. E. sericatum (Britz.)

Sacc.

Lactarius deterrimus Gröger

L. scrobiculatus (Scop.: Fr.) Fr.

L. necator (J. F. Gmel.: Fr.) Pers.

L. torminosus (Schaeff.: Fr.) Pers.

L. uvidus (Fr.: Fr.) Fr.

L. musteus Fr.

L. trivialis (Fr.: Fr.)Fr.

L. utilis (Wein.) Fr.

L. vietus (Fr.) Fr.

L. glyciosmus (Fr.: Fr.) Fr.

L. mammosus (Fr. ex Weinm.) Fr.

L. helvus (Fr.) Fr.

L. rufus (Scop.: Fr.) Fr.

L. theiogalus (Bull.: Fr.) S. F. Gray ss.

Neuhoff

L. camphoratus (Bull.: Fr.) Fr.

Russula adusta Fr.

$R$. claroflava Grove

$R$. foetens Pers.: Fr.

$R$. consobrina (Fr.: Fr.) Fr.

$R$. aeruginea Lindbl.

$R$. decolorans (Fr.) Fr.

R. paludosa Britz.

$R$. nitida (Pers.: Fr.) Fr.

$R$. vesca Fr.

(Contd.) 
Table 3. Contnd.

224. R. vinosa Lindbl.

225. R. xerampelina (Schaeff.) Fr.

226. $R$. emetica (Schaeff.: Fr.) Pers.

227. R. rhodopoda Zvára

228. $R$. betularum Hora

229. R. gracillima Schaeff.

230. Russula sp.

231. Lentinellus cochleatus (Pers.: Fr.) Karst.

232. L. omphalodes (Fr.) Karst.

2. Aphyllophorales

233. Cantharellus cibarius Fr.

234. C. tubaeformis Fr.

235. Clavaria argillacea Pers.: Fr.

236. Clavaria sp.

237. Clavariadelphus ligula (Schaeff.: Fr.) Donk

238. Ramaria sp.

239. Hydnum rufescens Fr.

240. Cytidia salicina (Fr.) Burt

241. Cylindrobasidium evolvens (Fr.: Fr.) Jülich

242. Merulius tremellosus Fr.

243. Plicatura nivea (Fr.) Karst.

244. Stereum sanguinolentum (Alb. \& Schw.: Fr.) Fr.

245. S. rugosum (Pers.: Fr.) Fr.

246. S. hirsutum (Willd.: Fr.) S. F. Gray

247. Phlebiopsis gigantea (Fr.) Jülich

248. Thelephora terrestris Pers.: Fr.

249. Hydnellum ferrugipes Coker

250. H. ferrugineum (Fr.: Fr.) Karst.

251. H. aurantiacum (Batsch : Fr.) Karst.

252. H. suaveolens (Scop.: Fr.) Karst.

253. Sarcodon imbricatus (L.: Fr.) Karst.

254. Bankera fuligineo-alba (Schmidt : Fr.) Pouzar

255. Phellodon tomentosus (L.: Fr.) Banker

256. Coltricia perennis (L.: Fr.) Murrill

257. Inonotus obliquus (Pers.: Fr.) Pilát

258. Phellinus pini (Brot.: Fr.) Ames

259. P. conchatus (Fr.) Quél.

260. P. tremulae (Bond.) Bond. \& Borisov. in Bond

261. P. nigricans (Fr.) Karst.

262. P. igniarius (L.: Fr.) Quél.

263. Ganoderma lipsiense (Batsch) Atk.

264. Scutiger confluens (Alb. \& Schw.: Fr.) Bond. \& Sing.

265. S. ovinus (Schaeff.: Fr.) Murrill

266. Piptoporus betulinus (Bull.: Fr.) Karst.

267. Hapalopilus rutilans (Pers.: Fr.) Karst.

268. Postia tephroleuca (Fr.) Jülich

269. Postia sp.

270. Bjerkandera adusta (Willd.: Fr.) Karst.

271. Cerrena unicolor (Bull.: Fr.) Murrill

272. Lenzites betulinus (L.: Fr.) Fr.

273. Pycnoporus cinnabarinus (Jacq.: Fr.) Karst.

274. Trametes multicolor (Schaeff.) Jülich

275. T. pubescens (Schum.: Fr.) Pilát

276. Trichaptum abietinum (Pers.: Fr.) Ryv.

277. T. hollii (J. C. Schmidt) Kreisel
278. Fomes fomentarius (L.: Fr.) Fr.

279. Fomitopsis pinicola (Sw.: Fr.) Karst.

280. Gloeophyllum sepiarium (Wulf.: Fr.) Karst.

281. Heterobasidion annosum (Fr.) Bref.

3. Heterobasidiomycetes

31. Tremellales

282. Exidia glandulosa Fr.

283. Pseudohydnum gelatinosum (Scop.: Fr.)

Karst.

284. Tremella mesenterica Retz.

285. T. foliacea Pers.: Pers.

32. Dacrymycetales

286. Calocera viscosa (Pers.: Fr.) Fr.

287. Dacrymyces stillatus Nees : Fr.

33. Exobasidiales

288. Exobasidium vaccinii (Fuckel) Woronin

289. E. karstenii Sacc. \& Trott.

290. E. sundstroemii Nannf.

4. Gasteromycetes

41. Lycoperdales

291. Bovista nigrescens Pers.: Pers.

292. Lycoperdon pyriforme Schaeff.: Pers.

293. L. perlatum Pers.: Pers.

\section{ASCOMYCOTINA}

\section{DISCOMYCETES}

1. Pezizales

294. Gyromitra esculenta (Pers.) Fr.

295. G. infula Schaeff.: Quél.

296. Peziza badia Pers.: Fr.

297. Peziza sp.

298. Otidea leporina (Batsch : Fr.) Fuck.

299. Scutellinia scutellata (L.: Fr.) Lambotte

300. Nannfeldtiella aggregata Eckbl.

301. Byssonectria aggregata (Berk. \& Broome) Rogerson \& Korf

2. Leotiales

302. Leotia lubrica Pers.: Fr.

303. Heyderia abietis (Fr.) Link

304. H. pusilla (Alb.: Schwein.) Link

305. Cudonia circinans (Pers.) Fr.

306. C. confusa Bres.

307. Rutstroemia firma (Pers.) Karst.

308. Ascocoryne sarcoides (Jacq.: Fr.) Groves \& Wilson

309. Bisporella citrina (Batsch : Fr.) Korf \&

310. Lachnellula subtilissima (Cooke) Dennis

\section{PYRENOMYCETES}

1. Clavicipitales

311. Cordyceps ophioglossoides (Ehrh.: Fr.)

312. Link

(Contd.) 
Table 3. Contnd.

\section{Sphaeriales}

313. Podostroma nybergianum Ulvinen, ined.

314. Nectria cinnabarina (Tode : Fr.) Fr.

315. Hypoxylon multiforme (Fr.: Fr.) Fr.

\section{PLECTOMYCETES}

1. Plectascales

316. Elaphomyces granulatus Fr.
Finnish forestry suffers great annual losses because of the damage to heartwood caused by many Aphyllophorales species, presented as wood saprophytes although many of them are also parasitic (Table 6). The species observed on live (and dying) trees growing on the sample plots were as follows: Phellinus pini (on pine), $P$. tremulae (on aspen) and $P$. nigricans, $P$. igniarius, Inonotus obliquus, Fomes fomentarius, Piptoporus betulinus (on birches) and Fomitopsis pinicola (on spruce). $F$. pinicola was observed to occur on spruce stumps although the species usually favours the boles of dead spruces as its substrate. Stereum sanguinolentum is a wound parasite of spruce; its spores infect live trees through above-ground root injuries, through holes made by increment bores and through pruning scars (Kauppila \& Niemelä 1986). S. sanguinolentum is presented as a wood saprophyte; each time it was observed, it had established itself on spruce stumps at sites that had been logged (Table 6).

The largest group of other saprophytes (Table 8) consisted of saprophytes feeding on forest and peatland mosses; these 17 species inhabited the uppermost forest moss layer (made up of Pleurozium schreberi, Dicranum polysetum, Hylocomnium splendens) of the mineral soil (podsol) type. The hyphae of the fungi are often below this live layer, in the litter and the dead part of the moss layer. The species of fungi that grew among Sphagnum species were classified as Sphagnum saprophytes.

Peat saprophytes (Table 8) grew in the peat substrate provided by the banks of peat alongside the ditches of drained areas. Omphalina umbellifera forms a symbiotic association with

Table 4. Distribution of macrofungi into different ecological groups.

I Mycorrhizal fungi of coniferous and deciduous trees - 125 species, $39.6 \%$

1. Scots pine (Pinus sylvestris) -51 species

2. Norway spruce (Picea abies) - 38 species

3. Downy birch (Betula pubescens) -29 species

4. Silver birch (Betula pendula) -6 species

5. Aspen (Populus tremula) -1 species

II Saprophytes- 184 species, $58.2 \%$

1. Wood saprophytes -82 species
11. Scots pine
12. Norway spruce
13. Silver and downy birch
14. Aspen
15. Grey alder (Alnus incana)
16. Rowan (Sorbus aucuparia)
17. Goat willow (Salix caprea)
18. Rotten conifer wood
19. Rotten deciduous wood

2. Litter saprophytes -71 species
21. Conifer and deciduous litter

22. Saprophytes specialising in certain parts of litter

221. Herbs and grasses

222. Needles of Scots pine and Norway spruce

223. Cones of Scots pine and Norway spruce

224. Aspen leaves

3. Moss saprophytes -17 species

31. Forest bryophytes

32. Sphagnum species on peatlands

4. Saprophytes on herbivore dung -5 species

5. Peat saprophytes -3 species

6. Saprophytes on an organic base in mineral soil 3 species

7. Fungal saprophytes -2 species

8. Saprophytes on burnt ground -1 species

III Parasites -7 species, $2.2 \%$

1. Trees -2 species

2. Dwarf-shrubs -3 species

3. Fungi -2 species 
Table 5. Mycorrhizal fungi of coniferous and deciduous tree species.

\begin{tabular}{|c|c|c|}
\hline Scots pine, 51 species & H. ferrugineum & Hydnum rufescens \\
\hline Suillus flavidus & $\begin{array}{l}\text { H. aurantiacum } \\
\text { H. suaveolens }\end{array}$ & Downy birch, 29 species \\
\hline S. luteus & Sarcodon imbricatus & Leccinum versipelle \\
\hline S. bovinus & Bankera fuligineo-alba & L. variicolor \\
\hline S. variegatus & Phellodon tomentosus & L. holopus \\
\hline $\begin{array}{l}\text { Boletus pinophilus } \\
\text { Tylopilus felleus }\end{array}$ & Elaphomyces granulatus & L. scabrum \\
\hline $\begin{array}{l}\text { Tylopilus felleus } \\
\text { Leccinum vulpinum }\end{array}$ & Norway spruce, 38 species & Paxillus involutus \\
\hline Comphidius roseus & & Tricholoma fulvum \\
\hline Chroogomphus rutilus & $\begin{array}{l}\text { Xerocomus subtomentosus } \\
\text { Chalciporus piperatus }\end{array}$ & Amanita vaginata \\
\hline Hygrophorus karstenii & $\begin{array}{l}\text { Chalciporus piperatus } \\
\text { Boletus edulis }\end{array}$ & A. muscaria \\
\hline H. hypothejus & $\begin{array}{l}\text { Boletus eaulls } \\
\text { Comphidius glutinosus }\end{array}$ & $\begin{array}{l}\text { Inocybe lanuginosa } \\
\text { Inocybe sp. }\end{array}$ \\
\hline H. camarophyllus & Hygrophorus piceae & $\begin{array}{l}\text { Inocybe sp. } \\
\text { Hebeloma crustuliniforme }\end{array}$ \\
\hline $\begin{array}{l}\text { Laccaria bicolor } \\
\text { Tricholoma nauseosum }\end{array}$ & H. olivaceoalbus & Hebeloma sp. \\
\hline $\begin{array}{l}\text { Tricholoma nauseosum } \\
\text { T. pessundatum }\end{array}$ & H. korhonenii & Naucoria sp. \\
\hline $\begin{array}{l}\text { T. pessundatum } \\
\text { T. portentosum }\end{array}$ & H. agathosmus & Cortinarius bolaris \\
\hline & H. pustulatus & C. triumphans \\
\hline $\begin{array}{l}\text { T. aestuans } \\
\text { T. flavovirens }\end{array}$ & Hygrophorus sp. & C. armillatus \\
\hline $\begin{array}{l}\text { T. flavovirens } \\
\text { Tricholoma } \mathrm{sp} .\end{array}$ & Laccaria laccata & C. paleaceus \\
\hline $\begin{array}{l}\text { Tricholoma sp. } \\
\text { Amanita fulva }\end{array}$ & L. proxima & C. hemitrichus \\
\hline $\begin{array}{l}\text { Amanita fulva } \\
\text { A. porphyria }\end{array}$ & Tricholoma inamoenum & Russula foetens \\
\hline Inocybe lacera & Amanita regalis & R. vinosa \\
\hline Hebeloma longicaudum & A. virosa & R. aeruginea \\
\hline Cortinarius huronensis & Cortinarius cinnamomeus & R. nitida \\
\hline C. croceus & C. sanguineus & R. betularum \\
\hline C. semisanguineus & C. orellanoides & R. gracillima \\
\hline C. gentilis & C. camphoratus & Russula sp. \\
\hline C. traganus & C. trivialis & Lactarius torminosus \\
\hline C. muscigenus & C. delibutus & L. uvidus \\
\hline C. mucosus & C. vibratilis & L. vietus \\
\hline C. laniger & C. evernius & Cantharellus cibarius \\
\hline C. obtusus & $\begin{array}{l}\text { C. brunneus } \\
\text { C. flexipes }\end{array}$ & Silver birch, 6 species \\
\hline $\begin{array}{l}\text { C. croceus } \\
\text { Rozites }\end{array}$ & Cortinarius spp. & Tricholoma album \\
\hline $\begin{array}{l}\text { Rozites caperatus } \\
\text { Russula adusta }\end{array}$ & Russula consobrina & T. virgatum \\
\hline $\begin{array}{l}\text { Russula adusta } \\
R \text { decolorans }\end{array}$ & R. xerampelina & Cortinarius pholideus \\
\hline $\begin{array}{l}R \text {. decolorans } \\
R \text { vesca }\end{array}$ & R. rhodopoda & C. anomalus \\
\hline $\begin{array}{l}R \text {. vesca } \\
R \text { paludosa }\end{array}$ & Lactarius scrobiculatus & Russula claroflava \\
\hline $\begin{array}{l}R . \text { paludosa } \\
R \text { emetica }\end{array}$ & L. deterrimus & Lactarius glyciosmus \\
\hline $\begin{array}{l}\text { R. emetica } \\
\text { Lactarius musteus }\end{array}$ & L. necator & \\
\hline $\begin{array}{l}\text { Lactarius musteus } \\
\text { L. helvus }\end{array}$ & L. utilis & Aspen, 1 species \\
\hline L. rufus & L. trivialis & Leccinum aurantiacum \\
\hline L. mammosus & L. camphoratus & \\
\hline Telephora terrestris & $\begin{array}{l}\text { L. theiogalus } \\
\text { Cantharellus tubaeformis }\end{array}$ & \\
\hline Hydnellum ferrugipes & & \\
\hline
\end{tabular}

green algae, and is considered to be a lichen (Heikkilä \& Kallio 1966). This symbiotic association may benefit $O$. umbellifera through the more active production of fruit bodies, for instance; $O$. umbellifera is common in the palsa bogs of Finnish Lapland (Tuomikoski 1960) and the raised bogs in the Jura mountains of Switzerland, where it grows among Sphagnum communities (Favre 1948).

Heterobasidion annosum is concidered here to be a parasite (alternatively also a wood saprophyte) (Table 9) that establishes itself in trees by infecting first the root of the tree and then the bole, eventually causing the tree to die. Tree death opens the way for a host of wood saprophytes (Cooke \& Rayner 1984). Another parasite of trees is Armillaria borealis (Table 9). Armillaria has been found to include both parasitic and saprophytic species (Korhonen 1978, Hansen \& Knudsen 1992). 
Table 6. Wood saprophytes. Gill fungi (agarics) underlined.

\begin{tabular}{|c|c|c|c|}
\hline $\begin{array}{l}\text { Tree species } \\
\text { and substrate }\end{array}$ & Trunks & Branches & Stumps \\
\hline Scots pine & \multicolumn{2}{|l|}{ Phellinus pini } & $\frac{\text { Lentinus lepideus }}{\text { Phlebiopsis gigantea }}$ \\
\hline $\begin{array}{l}\text { Norway } \\
\text { spruce }\end{array}$ & $\begin{array}{l}\text { Hygrophoropsis } \\
\text { aurantiaca } \\
\text { Pholiota flammans } \\
\text { Galerina marginata } \\
\text { Trichaptum abietinum } \\
T \text {. hollii }\end{array}$ & $\begin{array}{l}\text { Panellus mitis } \\
\text { Cylindrobasidium } \\
\text { evolvens } \\
\text { Dacrymyces } \\
\text { stillatus }\end{array}$ & $\begin{array}{l}\text { Paxillus atrotomentosus } \\
\text { Tricholomopsis decora } \\
\text { T. rutilans } \\
\text { Collybia acervata } \\
\frac{\text { Mycena viscosa }}{\text { M. laevigata }} \\
\frac{\text { M. stipata }}{\text { Xeromphalia campanella }} \\
\underline{\text { Hypholoma capnoides }} \\
\text { Pholiota scamba } \\
\text { Gymnopilus penetrans } \\
\text { Stereum sanguinolentum } \\
\text { Postia tephroleuca } \\
\text { Fomitopsis pinicola } \\
\text { Gloephyllum sepiarium } \\
\text { Pseudohydnum gelatinosum } \\
\text { Calocera viscosa } \\
\text { Ascocoryne sarcoides } \\
\text { Lachnellula subtilissima }\end{array}$ \\
\hline $\begin{array}{l}\text { Silver and } \\
\text { downy birch }\end{array}$ & $\begin{array}{l}\text { Pleurotus pulmonarius } \\
\text { Flammulina velutipes } \\
\text { Pluteus atricapillus } \\
\text { Inonotus obliquus } \\
\text { Phellinus nigricans } \\
\text { P. igniarius } \\
\text { Piptoporus betulinus } \\
\text { Lenzites betulinus } \\
\text { Trametes pubescens } \\
\text { Fomes fomentarius } \\
\text { Bisporella citrina }\end{array}$ & $\begin{array}{l}\text { Polyporus brumalis } \\
\text { P. varius } \\
\text { Lentinellus } \\
\text { omphalodes } \\
\text { Stereum rugosum } \\
\text { Postia sp. } \\
\text { Cerrena unicolor } \\
\text { Pycnoporus cinnabarinus } \\
\text { Tremella mesenterica } \\
\text { T. foliacea } \\
\text { Scutellinia scutellata } \\
\text { Nectria cinnabarina } \\
\text { Hypoxylon multiforme }\end{array}$ & $\begin{array}{l}\text { Polyporus ciliatus } \\
\text { Panellus serotinus } \\
\text { Mycena galericulata } \\
\text { Hypholoma lateritium } \\
\text { H. fasciculare } \\
\text { Kuehneromyces mutabilis } \\
\text { Lentinellus cochleatus } \\
\text { Merulius tremellosus } \\
\text { Stereum hirsutum } \\
\text { Bjerkandera adusta }\end{array}$ \\
\hline Aspen & \multicolumn{2}{|l|}{$\begin{array}{l}\text { Phellinus tremulae } \\
\text { Ganoderma lipsiense }\end{array}$} & Trametes multicolor \\
\hline Grey alder & $\frac{\text { Pholiota alnicola }}{\text { Plicatura nivea }}$ & $\begin{array}{l}\text { Exidia glandulosa } \\
\text { Rutstroemia firma }\end{array}$ & \\
\hline Rowan & $\underline{\text { Panus conchatus }}$ & & \\
\hline \multirow[t]{2}{*}{ Goat willow } & $\begin{array}{l}\text { Phellinus conchatus } \\
\text { Hapalopilus rutilans }\end{array}$ & Cytidia salicina & \\
\hline & \multicolumn{2}{|c|}{ Trunk, branches and stumps } & \\
\hline $\begin{array}{l}\text { Rotten } \\
\text { conifer wood }\end{array}$ & \multicolumn{2}{|c|}{$\begin{array}{l}\text { Megacollybia platyphylla } \\
\text { Galerina hypnorum ss. lat. } \\
\text { Pholiota sp. } \\
\text { Phaeocollybia sp. } \\
\text { Lycoperdon pyriforme } \\
\text { Gyromitra infula }\end{array}$} & \\
\hline $\begin{array}{l}\text { Rotten } \\
\text { deciduous } \\
\text { tree wood }\end{array}$ & \multicolumn{2}{|c|}{$\begin{array}{l}\text { Pluteus sp. } \\
\underline{\text { Tubaria confragosa }}\end{array}$} & \\
\hline
\end{tabular}


Ordination and classification of sample plots on the basis of macrofungi

\section{Mineral soil forest site types}

Ordination of the seventy-nine sample plots established on the basis of macrofungi in 1981 provided a complex picture. The greatest sample point values for axis 1 were obtained for the ECT sample plots. The sample plots closest to origin represented drained bogs and mires; mixed sample plots also occurred in different parts of the ordination, without any systematic order. This is understandable, as the mixed sample plots varied highly in their proportions of peatland and mineral soil and in their macrofungi. The greatest sample plot point values for axis 2 were obtained for the $\mathrm{LkN}$ sample plot, two virgin RaRs and four TRs, three of which were in the virgin state. With this initial analysis as the basis, the material was divided into the following strata: sample plots of the forest site type with mineral soil (34 in number); sample plots of the peatland site type

Table 7. Litter saprophytes.

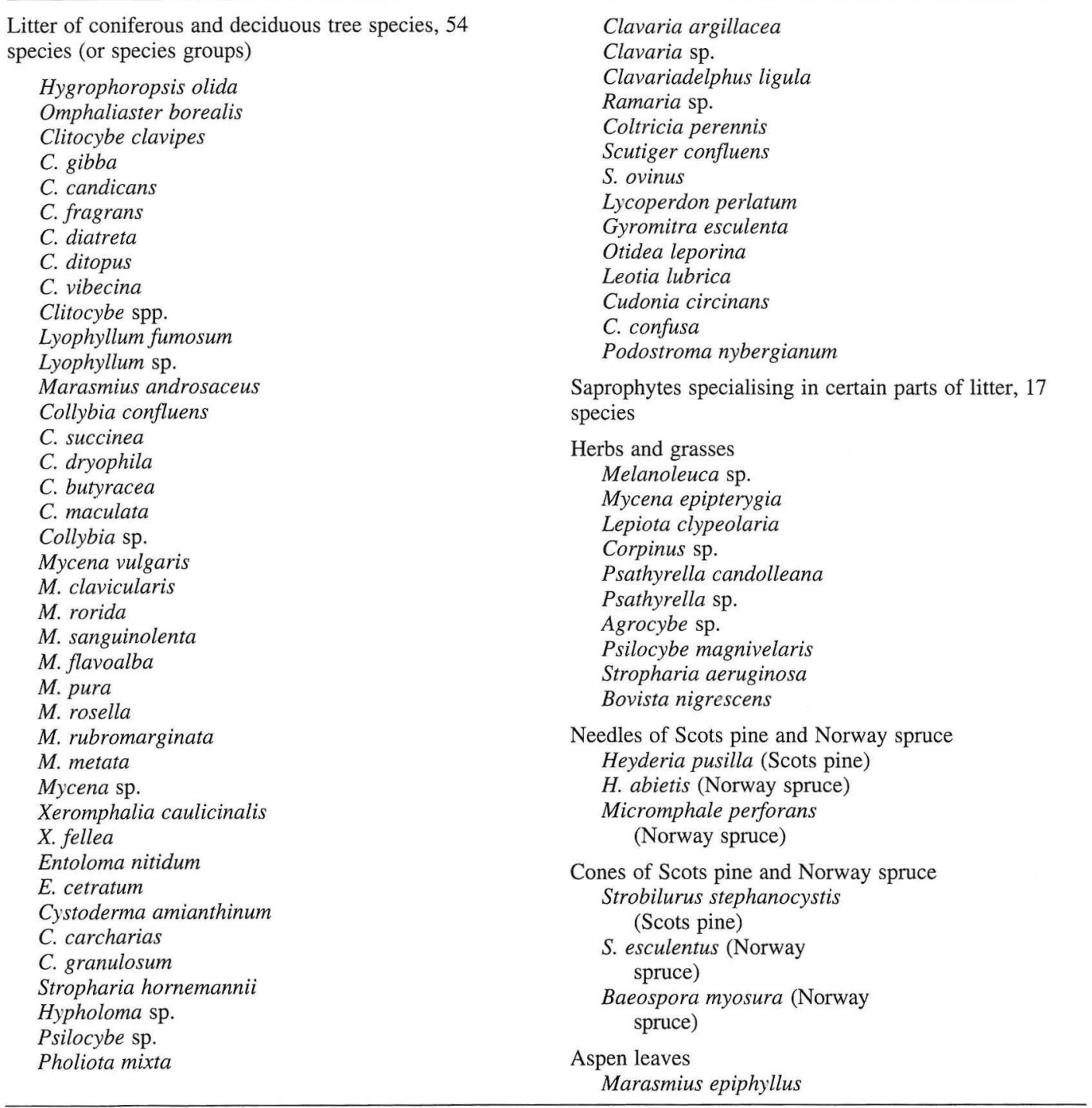


(27); and mixed sample plots (18), the last mentioned stratum containing elements of both forest and peatland site types in the one sample plot or two different forest or peatland site type segments.

The commonest dwarf shrubs on the forest site type sample plots were Vaccinium vitis-idaea and $V$. myrtillus; they were present on every sample plot (Table 10). Other common dwarf shrubs were Empetrum nigrum coll. (fr. 21) and Calluna vulgaris (fr. 21). Grasses and herbs were not abundant in the field layer. The commonest species was Deschampsia flexuosa (fr. 22). Forest mosses (Dicranum polysetum, Pleurozium schreberi, Dicranum scoparium, Hylocomium splendens) were common in the ground layer (Table 10). Lichens (e.g. Cladonia rangiferina, C. deformis, C. arbuscula) were common, and formed extensive communities on ECT and EVT sample plots.

The first axis of the DCA analysis is a complex one, depicting mainly the nutritional state; it is also associated with the tree species (Fig. 5). The highest values were obtained for sample plots representing dry mineral soil sites.
Sample plots representing the most fertile dryish and mesic mineral soil sites and rich mineral soil sites were located closer to the origin (Fig. 5).

In the TWINSPAN classification performed on the basis of the macrofungal species, dry heath forest soil sites and dryish and mesic heath forest soil sites emerged on the first divisional level (Fig. 6). The indicator species for dry heath forest mineral soil sites were Cortinarius semisanguineus, Suillus variegatus and Cortinarius croceus. Dryish and mesic heath forest mineral soil sites were characterised by Laccaria laccata, Mycena galopus, Hypholoma capnoides and Clitocybe spp. (Fig. 6).

On the second divisional level, where the dryish and mesic heath forest mineral soil sites were divided into two groups, the indicator species for mesic mineral soils sites were Cortinarius spp. Three sample plots in the group of dry heath forests soil sites; their indicator species were Cortinarius muscigenus and Mycena sanguinolenta (Fig. 6). The TWINSPAN classification was continued to the third divisional level, but owing to the small amount of material in question, it was not meaninful (from the ecological point of view) to

Table 8. Other saprophytes.

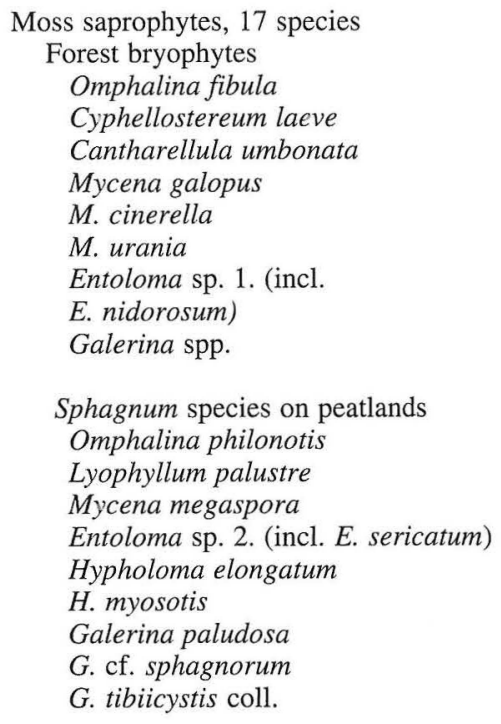

Saprophytes on herbivore dung, 5 species

Coprinus cinereus, Elk

C. radiatus, Elk

Stropharia semiglobata, Hare

Nannfeldtiella aggregata, Elk

Byssonectria aggregata, Elk

Peat saprophytes, 3 species

Omphalina umbellifera

O. oniscus

Hypholoma udum

Saprophytes on an organic base in mineral soil, 3 species Hohenbuehelia petaloides

Peziza badia

Peziza sp.

Fungal saprophytes on rotten Lactarius and Russula species, 2 species

Collybia tuberosa

C. cirrhata

Saprophyte on burnt ground, 1 species Fayodia maura 
Table 9. Parasites and hosts.

\begin{tabular}{cc}
\hline Tree parasites & Hosts \\
Armillaria borealis & Norway spruce \\
Heterobasidion annosum & Norway spruce \\
Dwarf-shrub parasites & \\
Exobasidium vaccinii & Vaccinium vitis-idaea \\
E. karstenii & Andromeda polifolia \\
E. sundstroemii & A. polifolia \\
Fungal parasites & \\
Cordyceps & Elaphomyces \\
ophioglossoides & granulatus \\
C. canadensis & Eranulatus \\
\hline
\end{tabular}

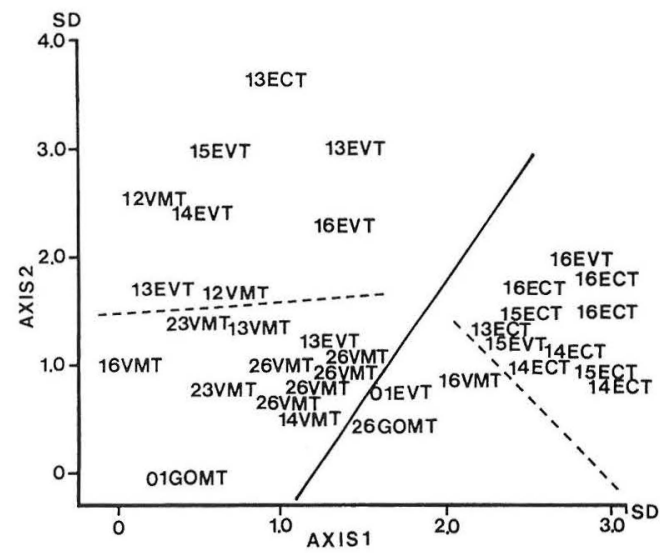

Fig. 5. DCA ordination of forest site types on the basis of macrofungi. TWINSPAN cut levels: 1 . division $=-$ 2. division $=-$---. Eigenvalues: 1 . axis $=0.494,2$. axis $=$ 0.376 . The numbers in front of the abbreviations for the forest site types represent the dominant tree species and development class. Dominant tree species: $0=$ Treeless site, 1 = Pine, 2 = Spruce, 3 = Silver birch, 4 = Downy birch. Development class: $0=$ Treeless site, $1=$ Open area or seed tree stand, $2=$ Small seedling stand, $3=$ Advanced seedling stand, $4=$ Young thinning stand, $5=$ Advanced thinning stand, $6=$ Mature stand, $7=$ Shelterwood stand.

try to interpret findings for the small groups obtained. According to the main division obtained with the TWINSPAN method, sample plots representing dryish and mesic heath forest soil sites dominated by spruce received lower values for the first axis than did pine-dominated sample plots.

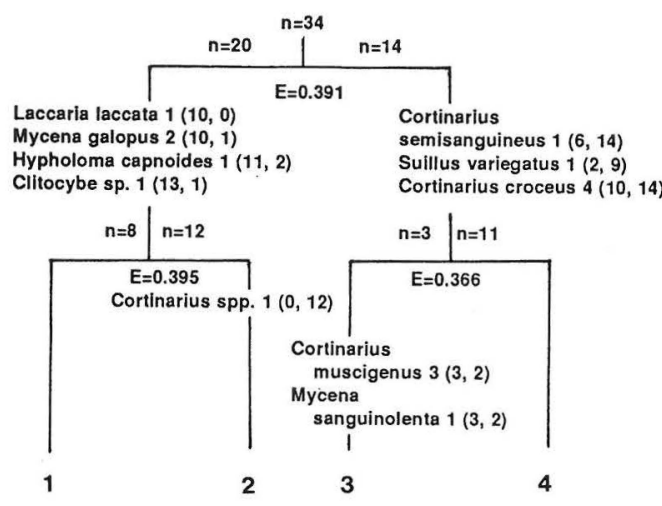

Fig. 6. TWINSPAN dendrogram of mineral forest site types on the basis of macrofungi. The indicator species of each division are given. The number after the name of a species gives the abundance value of pseudospecies formation. The numbers in parentheses give the frequencies of the species in the different grcups.

TWINSPAN Group 1 consisted mainly of sample plots representing dryish heath forest soil sites ( 5 xEVT, $2 \times$ VMT, 1 x ECT; Figs. 5 and 6). The dominant tree species was pine; five of the sample plots belonged to development classes 13 (young stands), in which the dominant height of the pines ranged from $2 \mathrm{~m}$ to $4 \mathrm{~m}$. The percentage of canopy cover on these sample plots was 5$10 \%$. Mycorrhizal species typical of dryish heath forest soil sites was Cortinarius brunneus, saprophytes being represented by Entoloma cetratum and Mycena clavicularis (Table 11). Lactarius rufus was common (6 sample plots) only in the dryish forest site type.

TWINSPAN Group 2 consisted of sample plots representing ten VMT, one EVT and one GOMT. Five mature VMT sample plots dominated by spruce were situated in the middle of the group (Fig. 5). The growing stock on the sample plots was taller than that on sample plots of TWINSPAN Group 1. The canopy coverage of the trees ranged from $40 \%$ to $90 \%$ except for three sample plots (on GOMT, VMT and EVT site types), the canopy coverage of which was 10-20\%. Mycorrhizal species typical of mesic heath forest soil sites were Lactarius vietus and Cortinarius armillatus. Common saprophytes were abundant: Mycena vulgaris, M. galopus, Micromphale perforans, Collybia dryophila and C. succinea (Table 11). These fungi consumed tree litter, herbs and grasses of the field layer, and 
Table 10. Frequencies of the 20 most abundant plant species in the field and ground layers in mineral soil forest, peatland and mixed forest and peatland site types (fr. = frequency).

\begin{tabular}{|c|c|c|c|c|}
\hline $\begin{array}{l}\text { Dwarf shrubs, } \\
\text { herbs and grasses, } \\
\text { sedges and sedge-like plants } \\
\text { Mosses and lichens }\end{array}$ & $\begin{array}{l}\text { Forest site } \\
\text { types } \\
\mathrm{n}=34 \\
\mathrm{fr} .\end{array}$ & $\begin{array}{l}\text { Peatland site } \\
\text { types } \\
\mathrm{n}=27 \\
\text { fr. }\end{array}$ & $\begin{array}{l}\text { Mixed forest } \\
\text { and peatland } \\
\text { site types } \\
n=18 \\
\text { fr. }\end{array}$ & $\begin{array}{l}\text { Total } \\
\text { fr. }\end{array}$ \\
\hline Vaccinium vitis-idaea & 34 & 19 & 16 & 69 \\
\hline V. myrtillus & 34 & 18 & 17 & 69 \\
\hline Empetrum nigrum coll. & 21 & 20 & 12 & 53 \\
\hline Vaccinium uliginosum & - & 22 & 11 & 33 \\
\hline Deschampsia flexuosa & 22 & - & 10 & 32 \\
\hline Rubus chamaemorus & - & 21 & 10 & 31 \\
\hline Carex globularis & - & 14 & 15 & 29 \\
\hline Melampyrum pratense & 15 & - & 8 & 23 \\
\hline Calluna vulgaris & 21 & - & - & 21 \\
\hline Eriophorum vaginatum & - & 18 & - & 18 \\
\hline Andromeda polifolia & - & 17 & - & 17 \\
\hline Ledum palustre & 8 & - & 8 & 16 \\
\hline Chamaedaphne calyculata & - & 15 & - & 15 \\
\hline Betula nana & - & 14 & - & 14 \\
\hline Solidago virgaurea & 14 & - & - & 14 \\
\hline Luzula pilosa & 10 & - & - & 10 \\
\hline Epilobium angustifolium & 10 & - & - & 10 \\
\hline Linnea borealis & - & - & 9 & 9 \\
\hline Pleurozium schreberi & 32 & 24 & 18 & 74 \\
\hline Dicranum polysetum & 34 & 17 & 16 & 67 \\
\hline Cladonia rangiferina & 26 & 16 & 11 & 53 \\
\hline Polytrichum commune & 19 & 16 & 12 & 47 \\
\hline Sphagnum angustifolium & - & 24 & 13 & 37 \\
\hline Hylocomium splendens & 21 & - & 15 & 36 \\
\hline Cladonia deformis & 21 & - & 14 & 35 \\
\hline Sphagnum russowii & - & 22 & 12 & 34 \\
\hline Dicranum scoparium & 21 & - & 11 & 32 \\
\hline Polytrichum strictum & - & 21 & 11 & 32 \\
\hline Cladonia arbuscula & 22 & - & - & 22 \\
\hline Aulacomnium palustre & - & 21 & - & 21 \\
\hline Cladonia cornuta & 18 & & - & 18 \\
\hline Sphagnum magellanicum & - & 17 & - & 17 \\
\hline Cladonia gracilis & 16 & & - & 16 \\
\hline Sphagnum fuscum & - & 13 & - & 13 \\
\hline
\end{tabular}

mosses of the ground layer. The plant material available on mesic sites was more versatile than that on dryish or dry sites.

TWINSPAN Group 3 had the following composition: a mature GOMT sample plot dominated by spruce close to the sample plots of Group 2; a treeless EVT regeneration site; and a mature VMT sample plot dominated by pine (Fig. $5)$. The ground layer was characterised by an extensive cover of two forest mosses, Pleurozium schreberi and Hylocomium splendens. Species of macrofungi commonplace on the sample plots included Cortinarius muscigenus and Mycena sanguinolenta; these did not occur abundantly on any other sample plots of forest type. Another feature of the sample plots was the relative rarity of mycorrhizal fungi and the abundance of saprophytes, for which reason these sample plots stood out from among the rest in the TWINSPAN classification even though, in terms of their plant species composition (field and ground layers), they would have been classified into the category of mesic heath forest mineral soil sites. 
Table 11. Frequencies of the 29 most abundant mycorrhizal (M), saprophytic litter (L) and wood-rotting (W), and parasitic (P) macrofungus species. Total number of macrofungi in parentheses in each forest site type (fr. $=$ frequency).

\begin{tabular}{|c|c|c|c|c|c|c|}
\hline Macrofungi & & $\begin{array}{l}\text { ECT } \\
\mathrm{n}=10 \\
(59) \\
\text { fr. }\end{array}$ & $\begin{array}{l}\text { orest site } \\
\text { EVT } \\
\text { DeMT } \\
\mathrm{n}=9 \\
(72) \\
\text { fr. }\end{array}$ & $\begin{array}{l}\mathrm{n}=34 \\
\text { VMT } \\
\mathrm{n}=13 \\
(102) \\
\text { fr. }\end{array}$ & $\begin{array}{l}\text { GOMT } \\
\mathrm{n}=2 \\
(25) \\
\text { fr. }\end{array}$ & Total fr. \\
\hline Marasmius androsaceus & (L) & 8 & 7 & 10 & 2 & 27 \\
\hline Galerina spp. & (L) & 8 & 7 & 10 & 1 & 26 \\
\hline Cortinarius croceus & (M) & 9 & 5 & 10 & - & 24 \\
\hline Cystoderma amianthinum & (L) & 8 & 6 & 7 & - & 21 \\
\hline Entoloma cetratum & (L) & 8 & 9 & 3 & - & 20 \\
\hline Cortinarius semisanguineus & (M) & 9 & 6 & 5 & - & 20 \\
\hline Collybia tuberosa & (L) & 3 & 3 & 9 & 2 & 17 \\
\hline Mycena clavicularis & (L) & 6 & 8 & 2 & - & 16 \\
\hline M. vulgaris & (L) & - & 2 & 10 & 2 & 14 \\
\hline Gymnopilus penetrans & (W) & 4 & 5 & 4 & - & 13 \\
\hline Hypholoma capnoides & (W) & 2 & 4 & 6 & 1 & 13 \\
\hline Clitocybe spp. & (L) & - & 4 & 7 & 1 & 12 \\
\hline Cortinarius spp. & (M) & - & 1 & 10 & 1 & 12 \\
\hline Suillus variegatus & (M) & 6 & 1 & 4 & - & 11 \\
\hline Mycena galopus & (L) & - & 1 & 9 & 1 & 11 \\
\hline Cortinarius brunneus & (M) & 2 & 6 & 3 & - & 11 \\
\hline C. cinnamomeus & (M) & 6 & 2 & 2 & - & 10 \\
\hline Laccaria laccata & (M) & - & 2 & 6 & 2 & 10 \\
\hline Lactarius vietus & (M) & - & 2 & 8 & - & 10 \\
\hline Cortinarius gentilis & (M) & 5 & - & 5 & - & 10 \\
\hline Micromphale perforans & (L) & - & - & 7 & 2 & 9 \\
\hline Chroocomphus rutilus & (M) & 4 & 1 & 4 & - & 9 \\
\hline Cantharellula umbonata & (L) & 3 & 4 & 1 & - & 8 \\
\hline Collybia dryophila & (L) & - & 1 & 7 & - & 8 \\
\hline C. succinea & (L) & - & 2 & 6 & - & 8 \\
\hline Tricholoma flavovirens & (M) & 6 & 1 & - & - & 7 \\
\hline Paxillus involutus & (M) & - & 3 & 2 & 2 & 7 \\
\hline Cortinarius armillatus & (M) & - & 1 & 6 & - & 7 \\
\hline Armillaria borealis & (P) & 1 & 2 & 3 & 1 & 7 \\
\hline
\end{tabular}

TWINSPAN Group 4 consisted of nine dry (ECT) and two dryish (EVT) heath forest mineral soil sites dominated by pine; the canopy coverage on all these sample plots averaged $40 \%$. The sample plots contained an abundance of dwarf shrubs and lichens and only a couple of grass and herb species. Species of mycorrhizal fungi typical of dry heath forest mineral soil sites included Cortinarius semisanguineus, C. croceus, C. cinnamomeus, Suillus variegatus and Tricholoma flavovirens (Table 11).

Saprophytes were fewer in number on dry mineral soil sites than on sites representing the other forest site types. The following species occurred as saprophytes common to all forest site types: Marasmius androsaceus on the branches of coniferous and deciduous trees, on needles, pieces of bark, cones and on decomposing leaves; Collybia tuberosa in the decomposing fruit bodies of other fungi; and Hypholoma capnoides in decaying conifer wood. Cystoderma amianthinum was common as a decaying agent of forest mosses, Mycena clavicularis being common on dry and dryish heath mineral forest soils among pine needles (Table 11).

The greatest number (102) of macrofungus species grew on mesic (VMT) sites (Table 11). In all, 138 macrofungus species (Table 14) and 102 plant species were identified in forest site types in 1981. 


\section{Peatland site types}

The peatland sample plots differed from each other distinctly when subjected to DCA grouping on the basis of macrofungi species (Fig. 7). The main gradient (eigenvalue 0.504 ) was interpreted as being chiefly a fertility axis, though its complexity is indicated by the bog-mire gradient, the centreedge gradient, and the pine-spruce (birch) tree species gradient. The beginning of axis 1 included nutrient-poor Eriophorum vaginatum pine bog sample plots ( $3 \times$ TRlt, $1 \times$ TRoj), and the greatest values on axis 1 were obtained for the fertile spruce mire sample plots $(2 \times$ RhKlt, $1 \times$ MKlt, $1 \times \mathrm{MKmu})$ (Fig. 7). The sample plots midway along axis 1 correspond to the 3rd and 4th fertility classes as defined by Huikari (1974) (Fig. 7).

There were 27 peatland sample plots in the material for 1981; on the first divisional level of the TWINSPAN classification these were separated mainly into spruce mires and pine bogs (Figs. 7 and 8). The indicator species on sample plots representing spruce mires and transitional pine mires and bogs were Mycena vulgaris and Micromphale perforans (Fig. 8), which were also common on mesic forest site types. M. perforans grew in spruce needle litter in fertile spruce mires and in transitional pine mires and bogs which, alongside pine, had admixtures of spruce and birch as part of the growing stock.

The other main group consisted of virgin and drained bogs of 5th and 6th fertility classes (Huikari 1974), two mires (PsR) of the 4th fertility class, and one treeless ombrotrophic small sedge bog $(\mathrm{LkN})$ (Fig. 7). Cortinarius huronensis was the indicator species (Fig. 8); it occurred as a mycorrhizal fungus of pine in the Sphagnum surfaces of all pine bog sample plots.

The dominant tree species on the treed sample plots of TWINSPAN Group 1 was pine, and the average height of the trees ranged from $2 \mathrm{~m}$ to $7 \mathrm{~m}$. Each sample plot had an abundance of dwarf shrubs with high coverage percentages; there were few grasses and herbs, the most common species being Rubus chamaemorus. Of the sedge-like plants, Eriophorum vaginatum was the commonest, forming extensive communities on virgin and drained Eriophorum vaginatum pine bogs (TR).

The commonest mycorrhizal species growing on nutrient-poor pine bogs (both virgin and drained) were Cortinarius huronensis, Laccaria laccata, Lactarius rufus, Cortinarius semisanguineus and Suillus variegatus (Table 12). Russula emetica is also a species inhabiting pine mires and bogs; it

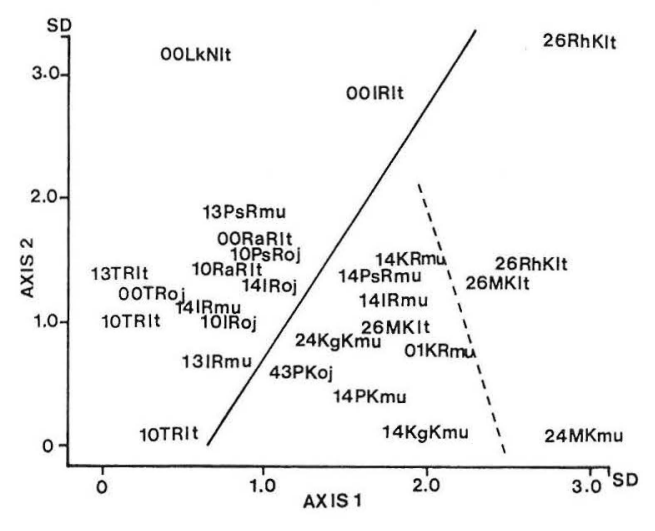

Fig. 7. DCA ordination of peatland site types on the basis of macrofungi. TWINSPAN cut levels: 1 . division $=-, 2$. division = ----. Eigenvalues: 1 . axis $=0.504,2$. axis $=$ 0.401. Other explanations as in Fig. 5.

was observed on sample plots which in the TWINSPAN classification belonged to Group 2. Common saprophytes were Galerina tibiicystis coll., G. paludosa and Omphalina umbellifera (Table 12), which grew in and among Sphagnum species and on the bare peat alongside ditches. Saprophytes feeding upon Sphagnum species on virgin bogs included Hypholoma elongatum, $H$. myosotis, Omphalina philonotis and Lyophyllum palustre.

Group 2 and Group 3 stood out on the second level of the TWINSPAN classification (Fig. 8). The former group was characterised by Lactarius vietus as the indicator species, the indicator species for the latter being Galerina tibiicystis coll. and Mycena sanguinolenta (Fig. 8). The drained spruce and pine mires of Group 2 represented young stands or young thinning stands dominated by pine, spruce or downy birch, and the height and canopy coverage of trees exceeded those of sample plots in Group 1 (Fig. 7). Of the sample plots belonging to this group, Vaccinium myrtillus spruce mire (MK) was in its virgin state, with a mature growing stock (Fig. 7). The four sample plots of the group (PsRmu, IRmu, 2xKRmu) were pine sites drained long ago, while the other KR sample plot of the group was a treeless regeneration site (Fig. 7).

The sample plots in Groups 2 and 3 were characterised by less dwarf shrubs and more herbs and grasses in the field layer than in the sample plots representing peatland Group 1 of pine bogs. 


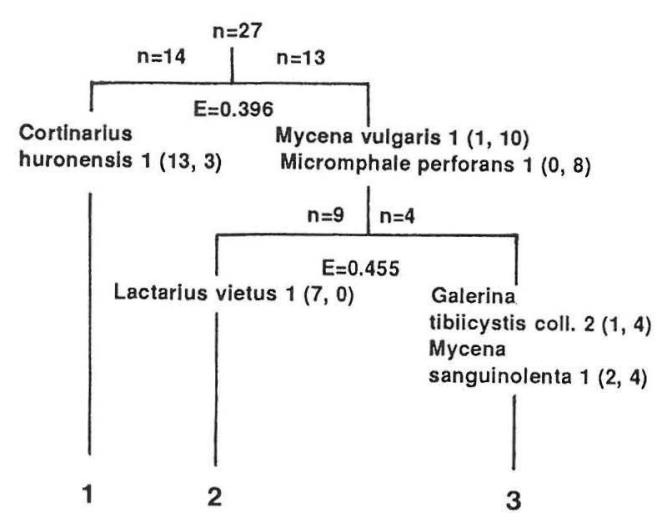

Fig. 8. TWINSPAN dendrogram of peatland site types on the basis of macrofungi. Explanations as in Fig. 6.

The commonest forest moss species was Pleurozium schreberi, the coverage of which was considerable on drained pine bogs (IR, PsR, KR) and on sample plots representing fertile spruce mires. Virgin pine bogs and recently drained pine bogs were marked by the total absence or relative rarity of $P$. schreberi. The commonest peatland mosses were Sphagnum angustifolium, $S$. magellanicum, S. fuscum and Polytrichum strictum on pine bogs and Sphagnum russowii and Polytrichum commune in spruce mires (Table 10).

Mycorrhizal species of pine typical of Group 2 were Russula paludosa and Cortinarius semisanguineus. Nearly all sample plots in the group included pine, spruce and downy birch, and the accompanying mycorrhizal species. Lactarius vietus grew in dense stands of spruce, while Paxillus involutus occurred under groups of downy birch (Table 12). It is difficult to specify any typical saprophytes, as Marasmius androsaceus was common in spruce mires and recently drained pine bogs (Table 12). Mycena vulgaris, M. galopus and Micromphale perforans grew in spruce stands in and among the forest mosses or litter of spruce needles (Table 12). The spruce and pine mire sample plots of the group were found to contain 67 species of macrofungi (Table 12). The other sample plot, representing an oligo-mesotrophic paludified spruce forest (transitional drained peatland, $\mathrm{KgKmu}$ ), the canopy coverage of which was $80 \%$ and development class 4, was found to contain the greatest number of macrofungus species -32 in all.

In the herb-rich hardwood-spruce mire of Group 3, the dominant tree species was spruce; three sample plots were mature stands, and one sample plot was a young thinning stand (Fig. 7). The growing stock in the mature stands was large in size, its height ranging from $14 \mathrm{~m}$ to $26 \mathrm{~m}$. Typical mycorrhizal species of this group were Russula nitida, Lactarius theiogalus, L. glyciosmus, Cortinarius sanguineus and C. armillatus. Saprophytes were plentiful on the sample plots; 28 species were identified, eleven of which were of the genus Mycena, the most frequent being Mycena vulgaris, $M$. galopus, $M$. sanguinolenta and $M$. epipterygia. A total of 63 macrofungus species were identified on four sample plots of the group. The greatest number (34) of macrofungus species grew on a sample plot representing a Vaccinium myrtillus spruce mire (MKmu). In all, 106 macrofungus species (Table 14) and 109 plant species were identified in peatland site types.

\section{Mixed forest and peatland site types}

In the DCA ordination of the mixed sample plots, Group 1 included sample plots $1,3,4,5$, 6; i.e. sample plots formed of site type segments with spruce mire or mesic forest (Fig. 9). Group 2 included the sample plots whose peatland segment corresponded to a mire or a bog with a fertility class of 2-5 and a forest segment from within the range of dry to rich heath forest (Fig. 9). In the TWINSPAN classification, the indicator species for the first divisional level were, on the left, Cortinarius spp. (small brown species of the subgenus Telamonia), C. gentilis and $C$. armillatus and, on the right, Paxillus involutus, Laccaria laccata and Hypholoma capnoides (Fig. 10).

Dwarf shrubs were common in the field layer on sample plots of both groups. Of the herbs and grasses, Rubus chamaemorus and Deschampsia flexuosa formed contiguous communities on some sample plots. In the ground layer, common heath forest moss species Pleurozium schreberi, Dicranum polysetum and Hylocomium splendens formed extensive communities on almost every sample plot. Sphagnum mosses occurred in both groups, on a total of sixteen sample plot; the most common ones were Sphagnum russowii in spruce mire segments and $S$. angustifolium in pine bog segments (Table 10). The groups differed from one another in their tree species composition; 
Table 12. Frequencies of the 28 most abundant mycorrhizal (M), saprophytic litter (L) and wood-rotting (W) macrofungus species. Total number of macrofungi in parentheses in each fertility class. Fertility classes (II-VI) of peatland site types as defined by Huikari (1974) (fr. = frequency).

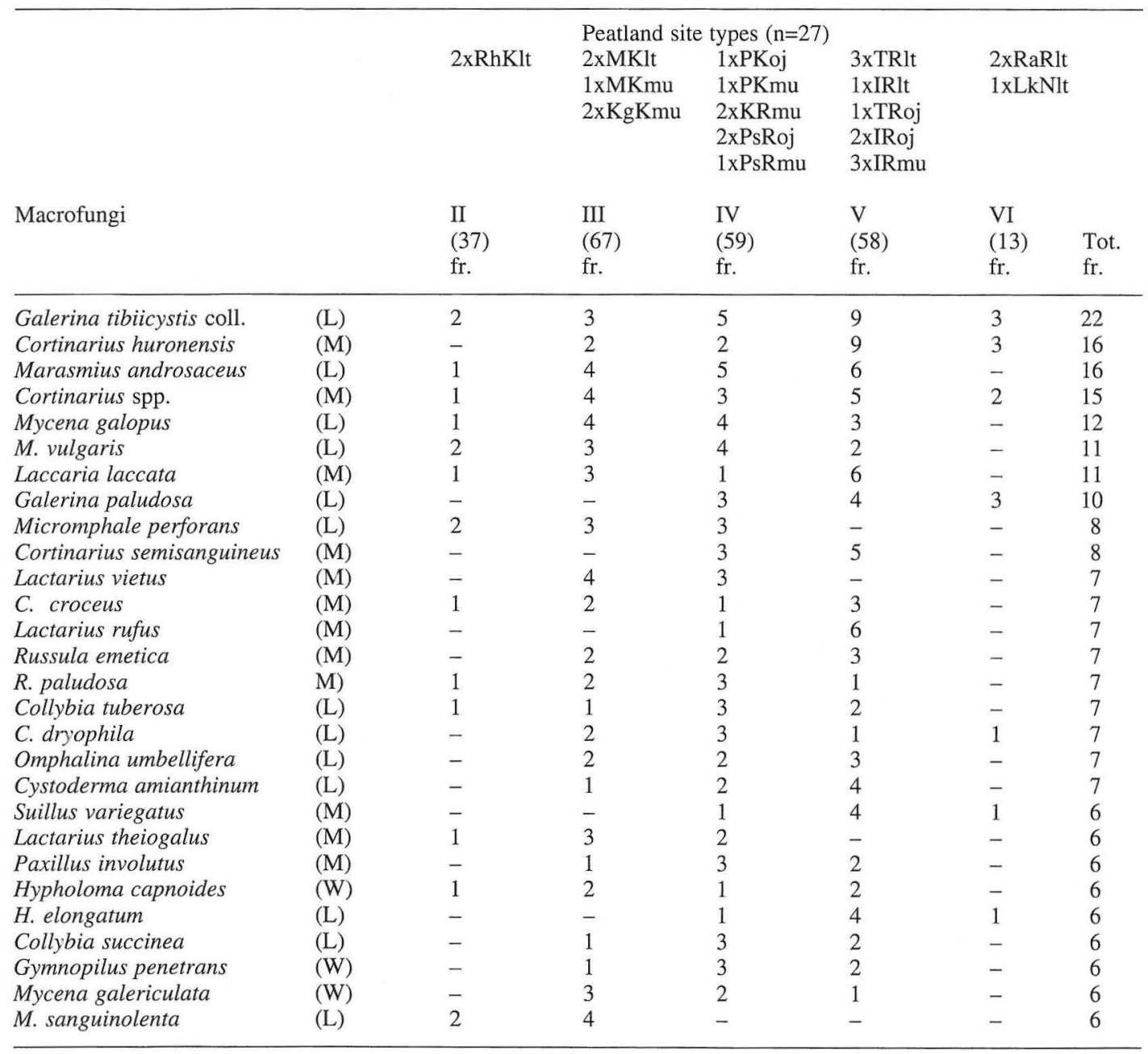

every sample plot (except sample plot 10) of Group 1 there had both spruce and downy birch trees, while the spruce mire segments also had goat willow and rowan. In the other group (consisting of 8 sample plots), only three sample plots had spruce trees, while pine was often the dominant species or an additional species.

Cortinarius croceus, C. semisanguineus, Suillus variegatus and Russula paludosa were the most abundant mycorrhizal species of pine (Table 13). Of the mycorrhizal fungus species of spruce, Laccaria laccata, Lactarius vietus, L. trivialis,
Cortinarius sanguineus and (those of birch) Cortinarius armillatus and Leccinum scabrum were common fungus species in the sample plots.

Litter saprophytes were common in both groups, the most common being Mycena galopus, M. vulgaris and Marasmius androsaceus (Table 13). Group 1 contained 77 macrofungus species, and Group 2 contained 95 macrofungus species (Table 13). The ordination and classification of mixed sample plots indicated that the more vegetational (i.e. site quality) variety there was on the sample plots, the more diverse the fungus 


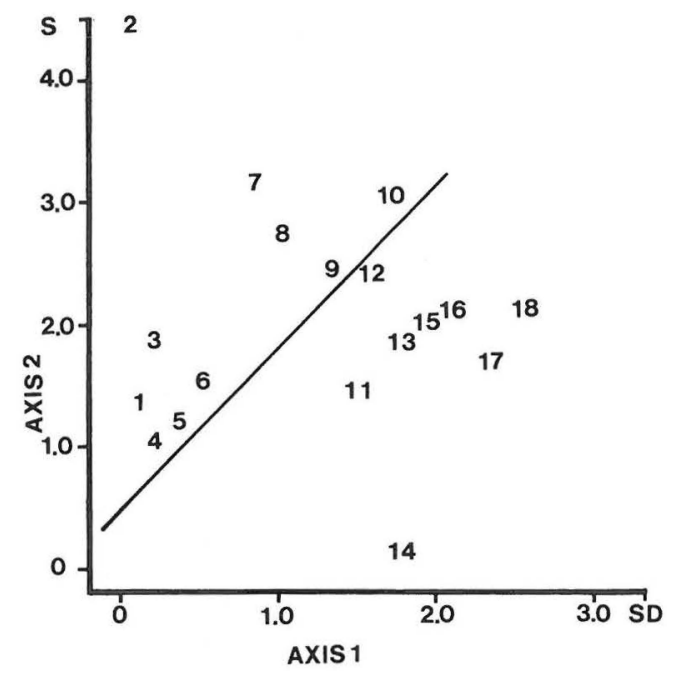

Fig. 9. DCA ordination of mixed forest and peatland site types on the basis of macrofungi. TWINSPAN cut level: 1 . division $=$. Eigenvalues: 1 . axis $=0.507,2$. axis $=$ 0.418. Other explanations as in Fig. 5. Sample plot number and forest and peatland site types and their relative proportion in each sample plot as follows: $1=26 \mathrm{MK} 95 \%$ $+24 \mathrm{KgK} 5 \%, 2=13 \mathrm{ECT} 50 \%+13 \mathrm{PsR} 30 \%+13 \mathrm{IR} 20 \%, 3$ $=14 \mathrm{KR} 90 \%+26 \mathrm{VMT} 10 \%, 4=26 \mathrm{RhK} 80 \%+26 \mathrm{MK} 20 \%$, $5=14 \mathrm{PK} 70 \%+23 \mathrm{VMT} 30 \%, 6=43 \mathrm{KgK} 90 \%+$ $23 \mathrm{RhK} 10 \%, 7=16 \mathrm{EVT} 80 \%+26 \mathrm{VMT} 20 \%, 8=$ $10 \mathrm{IRmu} 95 \%+00 \mathrm{LkN} 5 \%, 9=14 \mathrm{Vtkg} 60 \%+14 \mathrm{EVT} 40 \%$, $10=10 \mathrm{IR} 60 \%+10 \mathrm{VSR} 40 \%, 11=45 \mathrm{GOMT} 50 \%+$ $15 \mathrm{VMT} 50 \%, 12=13 \mathrm{ECT} 90 \%+10 \mathrm{IR} 10 \%, 13=$ $43 \mathrm{PKmu} 60 \%+13 \mathrm{PsR} 40 \%, 14=26 \mathrm{VMT} 95 \%+$ $14 \mathrm{KgK} 5 \%, 15=14 \mathrm{ECT} 85 \%+15 \mathrm{EVT} 15 \%, 16=$ $26 \mathrm{VMT} 90 \%+16 \mathrm{PK} 10 \%, 17=12 \mathrm{VMT} 70 \%+42 \mathrm{RhK} 30 \%$, $18=14 \mathrm{Vtkg} 70 \%+12 \mathrm{EVT} 30 \%$.

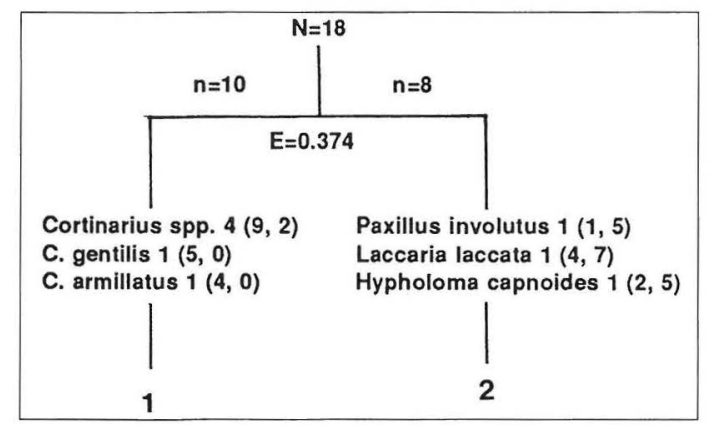

Fig. 10. TWINSPAN dendrogram of mixed forest and peatland site types on the basis of macrofungi. Explanations as in Fig. 6. communities were. In all, 121 macrofungus species (Table 14) and 106 plant species were identified on the mixed sample plots.

Plant and macrofungus species and communities

Forest and peatland site types were classified on the basis of the frequencies of dominant plant species (Table 10). Macrofungus communities were classified on the basis of the frequencies of the most abundant mycorrhizal and saprophytic species in forest site types (Table 11) and peatland site types (Table 12). Plant and macrofungus communities were characterized by a few species (generally 5-6 dominant species). Seven plant and macrofungus communities typical of a particular forest site type and peatland site type group are given here.

\section{Empetrum-Calluna Type (ECT)}

Vaccinium vitis-idaea - Calluna vulgaris - Empetrum nigrum coll. - Pleurozium schreberi - Cladonia spp.

Cortinarius semisanguineus - C. croceus - Suillus variegatus - Tricholoma flavovirens - Marasmius androsaceus - Cystoderma amianthinum

\section{Empetrum-Vaccinium Type (EVT)}

Vaccinium vitis-idaea - V. myrtillus - Empetrum nigrum coll. - Pleurozium schreberi - Dicranum polysetum

Cortinarius brunneus - C. semisanguineus Lactarius rufus - Entoloma cetratum - Mycena clavicularis - Marasmius androsaceus

\section{Vaccinium myrtillus Type (VMT) and Deschampsia-Myrtillus Type (DeMT)}

Vaccinium myrtillus - V. vitis-idaea -Deschampsia flexuosa - Pleurozium schreberi-Dicranum polysetum - Hylocomium splendens

Cortinarius spp. - Lactarius vietus - Cortinarius armillatus - Galerina spp. - Mycena vulgaris - $M$. galopus - Micromphale perforans

4. Peatland site types $P S R, I R, T R$, fertility classes $I V-V$; contain drained sites

Betula nana - Vaccinium uliginosum - Empetrum nigrum coll. - Eriophorum vaginatum - Rubus chamaemorus Sphagnum fuscum $-S$. russowii $-S$. angustifolium Polytrichum strictum 
Table 13. Frequencies of the 27 most abundant mycorrhizal (M), saprophytic litter (L) and wood-rotting (W) macrofungus species in mixed forest and peatland site types. The total number of macrofungi is given in parentheses for each TWINSPAN group (fr. = frequency).

\begin{tabular}{lccc}
\hline & TWINSPAN Group 1 & TWINSPAN Group 2 & Total \\
Macrofungi & $\mathrm{n}=10$ & $\mathrm{n}=8$ & fr. \\
& $(77)$ & $(95)$ & \\
& fr. & fr. & \\
\hline
\end{tabular}

\begin{tabular}{lllll}
\hline Mycena galopus & (L) & 9 & 6 & 15 \\
Marasmius androsaceus & (L) & 8 & 6 & 14 \\
Mycena vulgaris & (L) & 6 & 7 & 13 \\
Galerina spp. & (L) & 8 & 5 & 13 \\
G. tibiicystis coll. & (L) & 7 & 6 & 13 \\
Laccaria laccata & (M) & 4 & 7 & 11 \\
Cortinarius croceus & (M) & 9 & 2 & 11 \\
Cortinarius spp. & (M) & 9 & 2 & 11 \\
Mycena clavicularis & (L) & 5 & 5 & 10 \\
Collybia tuberosa & (L) & 4 & 6 & 10 \\
Lactarius vietus & (M) & 5 & 5 & 10 \\
Suillus variegatus & (M) & 5 & 4 & 9 \\
Micromphale perforans & (L) & 6 & 2 & 8 \\
Collybia succinea & (L) & 4 & 4 & 8 \\
Cortinarius semisanguineus & (M) & 5 & 2 & 7 \\
C. muscigenus & (M) & 6 & 1 & 7 \\
Collybia dryophila & (L) & 4 & 3 & 7 \\
Cystoderma amianthinum & (L) & 3 & 4 & 7 \\
Entoloma cetratum & (L) & 2 & 5 & 7 \\
Hypholoma capnoides & (W) & 2 & 5 & 6 \\
Russula paludosa & (M) & 3 & 3 & 6 \\
Cortinarius huronensis & (M) & 5 & 1 & 6 \\
Paxillus involutus & (M) & 1 & 5 & 6 \\
Cortinarius gentilis & (M) & 6 & - & 6 \\
Mycena galericulata & (W) & 2 & 4 & 6 \\
M. epipterygia & (L) 1 & 5 & 3 \\
Micromphale perforans & (L) 3 & & \\
\hline
\end{tabular}

Cortinarius huronensis - Lactarius rufus Laccaria laccata - Cortinarius semisanguineus Galerina tibiicystis coll. - Marasmius androsaceus

5. Virgin peatland site types TR, RaR, $L k N$, fertility classes $V-V I$

Vaccinium uliginosum - Chamaedaphne calyculata -Andromeda polifolia - Eriophorum vaginatum Sphagnum fuscum - S. russowii

Cortinarius huronensis - Galerina paludosa Hypholoma elongatum — Lyophyllum palustre

6. Drained peatland site types $K g K, P K, K R$, fertility classes III-IV

Vaccinium myrtillus - V. vitis-idaea - Carex globularis - Polytrichum commune - Pleurozium schreberi
Lactarius vietus - Russula paludosa - Marasmius androsaceus - Mycena galopus - M. vulgaris Collybia dryophila (C. succinea)

7. Virgin peatland site types $\mathrm{RhK}, M K$ and drained MK, fertility classes II and III

Vaccinium myrtillus - Carex globularis - Sphagnum girgensohnii - Pleurozium schreberi

Lactarius theiogalus - Cortinarius armillatus - C. sanguineus - Russula nitida - Micromphale perforans - Mycena sanguinolenta - - M. epipterygia

Macrofungi in mineral soil forest and peatland site types in 1981-1984

In all, 232 macrofungus species or groups were identified in North Karelian forest and peatland site 
Table 14. Frequencies and the total number of macrofungus species in mineral soil forest $(\mathrm{F})$, peatland $(\mathrm{P})$ and mixed forest and peatland site types $(\mathrm{F}+\mathrm{P})$, and the total number of sample plots $(\mathrm{n})$ in $1981-1984 . \mathrm{M}=$ mycorrhizal species, $\mathrm{L}=$ litter saprophytes incl. saprophytes on mosses and peat, on an organic base in mineral soil or burnt ground and fungal and herbivore dung saprophytes, $\mathrm{W}=$ wood saprophytes, $\mathrm{P}=$ parasites ( $\mathrm{fr}$. = frequency).

\begin{tabular}{|c|c|c|c|c|c|c|c|c|c|c|c|c|c|c|}
\hline \multirow[t]{3}{*}{ Macrofungi } & \multicolumn{4}{|c|}{1981} & \multicolumn{3}{|c|}{1982} & \multicolumn{3}{|c|}{1983} & \multicolumn{3}{|c|}{1984} & \multirow{3}{*}{$\begin{array}{l}\text { Total } \\
\text { fr. }\end{array}$} \\
\hline & & $\mathrm{F}$ & $\mathrm{P}$ & $\mathrm{F}+\mathrm{P}$ & $\mathrm{F}$ & $\mathrm{P}$ & $\mathrm{F}+\mathrm{P}$ & $\mathrm{F}$ & $\mathrm{P}$ & $\mathrm{F}+\mathrm{P}$ & $\mathrm{F}$ & $\mathrm{P}$ & $\mathrm{F}+\mathrm{P}$ & \\
\hline & $\mathrm{n}=$ & 34 & 27 & 18 & 69 & 53 & 14 & 100 & 70 & 22 & 100 & 65 & 24 & \\
\hline * Cortinarius spp. & (M) & 25 & 15 & 11 & 25 & 8 & 4 & 56 & 30 & 11 & 21 & 13 & 3 & 222 \\
\hline ** Galerina spp. & (L) & 26 & 4 & 13 & 15 & - & - & 22 & 22 & 5 & 2 & 7 & 4 & 120 \\
\hline $\begin{array}{l}\text { Lactarius rufus } \\
\text { Cortinarius }\end{array}$ & (M) & 6 & 7 & 4 & 10 & 17 & 3 & 12 & 16 & 6 & 12 & 13 & 2 & 108 \\
\hline semisanguineus & (M) & 20 & 8 & 7 & 7 & 4 & 1 & 22 & 3 & 6 & 10 & 3 & - & 91 \\
\hline Laccaria laccata & (M) & 11 & 11 & 11 & 6 & 8 & - & 11 & 10 & 5 & 10 & 5 & 2 & 90 \\
\hline Collybia tuberosa & (L) & 17 & 7 & 10 & 10 & 9 & 2 & 13 & 5 & 4 & 1 & 2 & - & 80 \\
\hline Cortinarius croceus & (M) & 13 & 7 & 11 & 2 & 9 & 1 & 16 & 7 & 2 & 1 & 7 & 2 & 78 \\
\hline Micromphale & & & & & & & & & & & & & & \\
\hline $\begin{array}{l}\text { perforans } \\
\text { Marasmius }\end{array}$ & (L) & 9 & 8 & 8 & 14 & 5 & 3 & 13 & 4 & 5 & 6 & 2 & 1 & 78 \\
\hline androsaceus & (L) & 27 & 16 & 14 & 1 & - & - & 12 & 4 & 1 & 1 & - & - & 76 \\
\hline $\begin{array}{l}\text { Mycena galopus } \\
\text { Cortinarius }\end{array}$ & (L) & 12 & 12 & 15 & 5 & 6 & 1 & 7 & 9 & 4 & 2 & 1 & 1 & 75 \\
\hline armillatus & (M) & 7 & 3 & 5 & 8 & 2 & 2 & 26 & 10 & 6 & 8 & 1 & - & 75 \\
\hline Mycena sp. & (L) & 15 & 7 & 8 & 4 & 2 & - & 18 & 5 & 6 & 2 & 2 & 2 & 71 \\
\hline $\begin{array}{l}\text { Cystoderma } \\
\text { amianthinum } \\
\text { Cortinarius }\end{array}$ & (L) & 21 & 4 & 7 & 15 & 1 & 2 & 16 & 2 & 1 & - & 1 & - & 70 \\
\hline $\begin{array}{l}\text { muscigenus } \\
\text { Galerina tibiicystis }\end{array}$ & (M) & 6 & 3 & 7 & 6 & - & - & 22 & 4 & 2 & 10 & 3 & 1 & 64 \\
\hline & (L) & 12 & 22 & 13 & 1 & 11 & 1 & 1 & 1 & 1 & - & - & - & 63 \\
\hline Entoloma cetratum & (L) & 21 & - & 4 & 12 & - & - & 12 & - & 6 & 2 & - & - & 57 \\
\hline Russula emetica & (M) & 2 & 7 & 5 & 3 & 7 & 1 & 8 & 13 & 3 & 2 & 3 & 2 & 56 \\
\hline Lactarius vietus & (M) & 10 & 6 & 10 & - & 2 & - & 7 & 6 & 4 & 3 & 3 & - & 51 \\
\hline Mycena clavicularis & (L) & 16 & 1 & 10 & 4 & 4 & 1 & 7 & 5 & 2 & - & - & - & 50 \\
\hline Cortinarius gentilis & (M) & 10 & 1 & 6 & 7 & 1 & - & 15 & 2 & 4 & 2 & 1 & - & 49 \\
\hline Suillus variegatus & (M) & 11 & 6 & 9 & 4 & 1 & - & 7 & 1 & - & 6 & 1 & - & 46 \\
\hline Paxillus involutus & (M) & 7 & 6 & 6 & 3 & 10 & 1 & 1 & 4 & 4 & - & 1 & 1 & 44 \\
\hline$* *$ Clitocybe spp. & (L) & 12 & 5 & 5 & 2 & 2 & - & 4 & 7 & 2 & 2 & 1 & - & 42 \\
\hline Mycena vulgaris & (L) & 14 & 11 & 13 & - & 1 & - & 2 & 1 & - & - & - & - & 42 \\
\hline Russula paludosa & (M) & 5 & 7 & 6 & - & 4 & - & 2 & 10 & 5 & - & 2 & - & 41 \\
\hline saludosa & (L) & - & 10 & 5 & - & 7 & 4 & - & 6 & 3 & - & 6 & - & 41 \\
\hline Collybia dryophila & (L) & 8 & 7 & 7 & 1 & 2 & 1 & 2 & 5 & - & - & 6 & 1 & 40 \\
\hline $\begin{array}{l}\text { Rozites caperatus } \\
\text { Gymnophilus }\end{array}$ & (M) & 3 & 1 & 2 & - & - & - & 17 & 2 & 1 & 8 & 2 & - & 36 \\
\hline penetrans & (W) & 13 & 6 & 1 & 6 & - & - & 9 & - & - & 1 & - & - & 36 \\
\hline Russula decolorans & (M) & - & 5 & 3 & - & 1 & 1 & 9 & 3 & 1 & 7 & 3 & 2 & 35 \\
\hline $\begin{array}{l}\text { Cortinarius } \\
\text { cinnamomeus }\end{array}$ & (M) & 10 & 1 & 1 & 2 & 5 & - & 7 & 3 & 4 & - & 1 & - & 34 \\
\hline $\begin{array}{l}\text { Collybia succinea } \\
\text { Cortinarius }\end{array}$ & (L) & 8 & 6 & 8 & - & 1 & - & 6 & 4 & - & 1 & - & - & 34 \\
\hline $\begin{array}{l}\text { huronensis } \\
\text { Hypoloma }\end{array}$ & (M) & - & 16 & - & - & 4 & 1 & 1 & 7 & - & - & 2 & 1 & 32 \\
\hline capnoides & (W) & 13 & 6 & 7 & 2 & - & - & 3 & 1 & - & - & - & - & 32 \\
\hline Leccinum scabrum & (M) & 4 & 4 & 5 & 1 & 2 & - & 7 & 1 & 1 & 2 & 3 & 1 & 31 \\
\hline Lactarius theiogalus & $s(\mathrm{M})$ & 2 & 6 & 1 & 1 & 2 & 1 & - & 4 & 3 & 1 & 5 & 3 & 29 \\
\hline $\begin{array}{l}\text { Hebeloma sp. } \\
\text { Cantharellula }\end{array}$ & (M) & 7 & - & 3 & 4 & 2 & - & 3 & 3 & 2 & 1 & 1 & 1 & 27 \\
\hline umbonata & (L) & 8 & 4 & 3 & 2 & - & - & 7 & 1 & 1 & 1 & - & - & 27 \\
\hline
\end{tabular}


Table 14. contnd.

\begin{tabular}{|c|c|c|c|c|c|c|c|c|c|c|c|c|c|c|}
\hline \multirow[t]{3}{*}{ Macrofungi } & \multirow[b]{3}{*}{$\mathrm{n}=$} & \multicolumn{3}{|c|}{1981} & \multicolumn{3}{|c|}{1982} & \multicolumn{3}{|c|}{1983} & & \multicolumn{2}{|c|}{1984} & \multirow{3}{*}{$\begin{array}{l}\text { Total } \\
\text { fr. }\end{array}$} \\
\hline & & $\mathrm{F}$ & $\mathrm{P}$ & $\mathrm{F}+\mathrm{P}$ & $\mathrm{F}$ & & $\mathrm{F}+\mathrm{P}$ & $\mathrm{F}$ & $\mathrm{P}$ & $\mathrm{F}+\mathrm{P}$ & & & $\mathrm{F}+\mathrm{P}$ & \\
\hline & & 34 & 27 & 18 & 69 & 53 & 14 & 100 & 70 & 22 & 100 & 65 & 24 & \\
\hline $\begin{array}{l}\text { Mycena galericulata } \\
\text { Chroogomphus }\end{array}$ & $a(\mathrm{~W})$ & 5 & 6 & 6 & 4 & - & - & 2 & - & 1 & - & 2 & - & 26 \\
\hline rutilus & $(\mathrm{M})$ & 9 & 2 & 2 & 1 & 1 & - & 4 & 2 & - & 3 & 1 & - & 25 \\
\hline $\begin{array}{l}\text { Russula vinosa } \\
\text { Cortinarius }\end{array}$ & $(\mathrm{M})$ & 1 & 1 & 1 & - & 1 & - & 13 & 4 & 2 & 2 & - & - & 25 \\
\hline $\begin{array}{l}\text { brunneus } \\
\text { Omphalina }\end{array}$ & $(\mathrm{M})$ & 11 & 5 & 2 & 1 & 1 & 1 & 1 & 2 & - & - & - & - & 24 \\
\hline $\begin{array}{l}\text { umbellifera } \\
\text { Cortinarius }\end{array}$ & (L) & 2 & 7 & 2 & - & 8 & - & 1 & 3 & - & - & 1 & - & 24 \\
\hline mucosus & $(\mathrm{M})$ & 4 & 2 & 3 & 3 & - & 1 & 7 & 1 & 1 & - & - & - & 22 \\
\hline $\begin{array}{l}\text { Russula sp. } \\
\text { Entoloma sp. } 1 \text { (incl. }\end{array}$ & (M) & 3 & - & - & - & - & - & 10 & 2 & 1 & 5 & 1 & - & 22 \\
\hline E. nidorosum) & (L) & 6 & 5 & 7 & - & - & - & 3 & - & - & 1 & - & - & 22 \\
\hline Lactarius helvus & (M) & - & 4 & 3 & - & 3 & - & 4 & 3 & 1 & 1 & 1 & 1 & 21 \\
\hline $\begin{array}{l}\text { Russula claroflava } \\
\text { Lactarius }\end{array}$ & $(\mathrm{M})$ & - & 2 & 2 & - & 1 & - & 1 & 4 & 2 & 2 & 5 & 2 & 21 \\
\hline $\begin{array}{l}\text { mammosus } \\
\text { Stropharia }\end{array}$ & (M) & 5 & 2 & 1 & 2 & 1 & - & 1 & 1 & 1 & 3 & 1 & 2 & 20 \\
\hline $\begin{array}{l}\text { hornemannii } \\
\text { Entoloma sp. } 2 \\
\text { (incl. E. }\end{array}$ & (L) & 3 & 2 & 4 & 2 & 1 & 1 & 2 & 1 & 3 & - & 1 & - & 20 \\
\hline sericatum) & (L) & - & 1 & - & - & 7 & - & - & 7 & - & - & 4 & - & 19 \\
\hline $\begin{array}{l}\text { Mycena epipterygia } \\
\text { Lactarius }\end{array}$ & (L) & 6 & 5 & 6 & - & - & - & 2 & - & - & - & - & - & 19 \\
\hline glyciosmus & (M) & 4 & 1 & 4 & - & 1 & - & 1 & 4 & 2 & - & 1 & - & 18 \\
\hline Russula nitida & (M) & 1 & 4 & 3 & - & 5 & 2 & - & 1 & 2 & - & - & - & 18 \\
\hline $\begin{array}{l}\text { Polyporus ciliatus } \\
\text { Leccinum }\end{array}$ & (W) & 4 & 2 & 1 & 1 & - & 1 & 5 & 1 & - & 1 & 1 & - & 17 \\
\hline $\begin{array}{l}\text { vulpinum } \\
\text { Cortinarius }\end{array}$ & $(\mathrm{M})$ & 6 & - & 2 & 2 & - & - & 1 & - & - & 5 & 1 & - & 17 \\
\hline $\begin{array}{l}\text { pholideus } \\
\text { Hypholoma }\end{array}$ & (M) & 4 & 2 & 5 & - & - & - & 2 & - & 2 & - & 1 & - & 16 \\
\hline elongatum & $(\mathrm{L})$ & - & 5 & 1 & - & - & - & 1 & 6 & 3 & - & - & - & 16 \\
\hline Lactarius utilis & (M) & 2 & 2 & 2 & 2 & - & - & 4 & - & - & - & 1 & 1 & 14 \\
\hline Polyporus brumalis & (W) & 3 & 2 & 1 & 3 & - & 1 & 3 & - & - & 1 & - & - & 14 \\
\hline Lactarius trivialis & (M) & 2 & 2 & 2 & - & 2 & - & 3 & 2 & - & - & 1 & - & 14 \\
\hline $\begin{array}{l}\text { Armillaria borealis } \\
\text { Cortinarius }\end{array}$ & (P) & 7 & 1 & 2 & - & - & 1 & 3 & - & - & - & - & - & 14 \\
\hline traganus & (M) & 1 & 2 & 2 & 1 & - & - & 2 & 1 & - & 2 & 2 & - & 13 \\
\hline Galerina marginata & (W) & 5 & 1 & 2 & 2 & - & - & 2 & - & - & 1 & - & - & 13 \\
\hline Leccinum variicolor & $(\mathrm{M})$ & 3 & 3 & 3 & 1 & - & - & - & 1 & - & - & - & 1 & 12 \\
\hline $\begin{array}{l}\text { L. versipelle } \\
\text { Xeromphalia }\end{array}$ & (M) & 4 & 2 & - & - & - & - & - & 1 & 1 & 3 & - & 1 & 12 \\
\hline $\begin{array}{l}\text { caulicinalis } \\
\text { Russula }\end{array}$ & (L) & 4 & 3 & 3 & 1 & - & - & 1 & - & - & - & - & - & 12 \\
\hline $\begin{array}{l}\text { xerampelina } \\
\text { Mycena }\end{array}$ & $(\mathrm{M})$ & 3 & - & - & - & - & - & 5 & - & - & 3 & - & 1 & 12 \\
\hline sanguinolenta & (L) & 2 & 6 & 3 & - & - & 1 & - & - & - & - & - & - & 12 \\
\hline Clitocybe vibecina & (L) & 5 & 3 & 3 & - & - & - & - & 1 & - & - & - & - & 12 \\
\hline Pholiota sp. & (W) & 5 & - & 2 & 3 & - & - & 2 & - & - & - & - & - & $\begin{array}{l}12 \\
\text { tnd.) }\end{array}$ \\
\hline
\end{tabular}


Table 14. contnd.

\begin{tabular}{|c|c|c|c|c|c|c|c|c|c|c|c|c|c|c|}
\hline \multirow[t]{3}{*}{ Macrofungi } & \multirow[b]{3}{*}{$\mathrm{n}=$} & \multicolumn{3}{|c|}{1981} & \multicolumn{3}{|c|}{1982} & \multirow[b]{2}{*}{$\mathrm{F}$} & \multicolumn{2}{|c|}{1983} & \multirow[b]{2}{*}{$\mathrm{F}$} & \multicolumn{2}{|c|}{1984} & \multirow{3}{*}{$\begin{array}{l}\text { Total } \\
\text { fr. }\end{array}$} \\
\hline & & $\mathrm{F}$ & & $\mathrm{F}+\mathrm{P}$ & $\mathrm{F}$ & $\mathrm{P}$ & $\mathrm{F}+\mathrm{P}$ & & $\mathrm{P}$ & $\mathrm{F}+\mathrm{P}$ & & $\mathrm{P}$ & $\mathrm{F}+\mathrm{P}$ & \\
\hline & & 34 & 27 & 18 & 69 & 53 & 14 & 100 & 70 & 22 & 100 & 65 & 24 & \\
\hline $\begin{array}{l}\text { Clitocybe clavipes } \\
\text { Cystoderma }\end{array}$ & (L) & 5 & 1 & 2 & 1 & - & - & 1 & 1 & - & - & - & - & 11 \\
\hline $\begin{array}{l}\text { granulosum } \\
\text { Hypholoma }\end{array}$ & (L) & 3 & 2 & 3 & 1 & - & - & 1 & 1 & - & - & - & - & 11 \\
\hline $\begin{array}{l}\text { fasciculare } \\
\text { Mycena }\end{array}$ & $(\mathrm{W})$ & 2 & 4 & 1 & 2 & - & - & - & 1 & - & 1 & - & - & 11 \\
\hline rubromarginata & (L) & 3 & - & 4 & 2 & 1 & - & 1 & - & - & - & - & - & 11 \\
\hline$M$. rorida & (L) & 3 & 1 & 5 & - & 1 & - & 1 & - & - & - & - & - & 11 \\
\hline $\begin{array}{l}\text { Collybia cirrhata } \\
\text { Hygrophorus }\end{array}$ & (L) & 5 & - & - & - & - & - & - & - & - & 4 & 1 & 1 & 11 \\
\hline olivaceoalbus & $(\mathrm{M})$ & 2 & - & 2 & - & - & - & 3 & 4 & - & - & - & - & 11 \\
\hline $\begin{array}{l}\text { Mycena megaspora } \\
\text { Xerocomus }\end{array}$ & (L) & 1 & 3 & 2 & 1 & 1 & - & 1 & 1 & 1 & - & - & - & 11 \\
\hline $\begin{array}{l}\text { subtomentosus } \\
\text { Xeromphalia }\end{array}$ & $(\mathrm{M})$ & 2 & - & 1 & 1 & - & - & 2 & - & - & 3 & 1 & - & 10 \\
\hline campanella & (W) & 2 & 1 & 2 & - & 1 & - & 3 & - & 1 & - & - & - & 10 \\
\hline Hypholoma sp. & (L) & - & - & 2 & 2 & - & - & 1 & 1 & - & 2 & 2 & - & 10 \\
\hline $\begin{array}{l}\text { Inocybe sp. } \\
\text { Omphalina }\end{array}$ & $(\mathrm{M})$ & 2 & 1 & - & 1 & - & - & 4 & - & 1 & - & - & 1 & 10 \\
\hline philonotis & $(\mathrm{L})$ & 2 & 3 & - & - & 1 & - & - & 3 & - & - & 1 & - & 10 \\
\hline Inocybe lanuginosa & (M) & 2 & 5 & 2 & - & - & - & 1 & - & - & - & - & - & 10 \\
\hline Leccinum niveum & (M & - & 2 & 4 & - & - & - & - & 1 & 1 & - & - & 1 & 9 \\
\hline Collybia putilla & (L) & 3 & - & 1 & - & - & - & 2 & - & - & 3 & - & - & 9 \\
\hline Amanita fulva & (M) & 2 & 1 & 1 & - & - & - & 1 & 3 & - & - & - & - & 8 \\
\hline $\begin{array}{l}\text { Collybia butyracea } \\
\text { Cortinarius }\end{array}$ & (L) & 3 & - & 1 & - & - & - & 3 & 1 & - & 1 & - & - & 8 \\
\hline orellanoides & $(\mathrm{M})$ & 3 & - & 2 & - & 1 & - & - & - & 1 & - & 1 & - & 8 \\
\hline Mycena rosella & (L) & 1 & 2 & 2 & 1 & - & - & 2 & - & - & - & - & - & 8 \\
\hline M. pura & (L) & 4 & 1 & 2 & 1 & - & - & - & - & - & - & - & - & 8 \\
\hline $\begin{array}{l}\text { Panellus mitis } \\
\text { Cortinarius }\end{array}$ & (W) & 2 & 1 & 4 & - & - & - & - & 1 & - & - & - & - & 8 \\
\hline $\begin{array}{l}\text { sanguineus } \\
\text { Pleurotus }\end{array}$ & $(\mathrm{M})$ & 2 & - & 2 & - & 1 & - & 1 & - & 1 & - & - & - & 7 \\
\hline pulmonarius & (W) & 3 & 1 & 2 & - & - & - & - & 1 & - & - & - & - & 7 \\
\hline Hypholoma udum & (L) & - & 1 & 1 & - & 3 & - & - & 2 & - & - & - & - & 7 \\
\hline $\begin{array}{l}\text { Amanita vaginata } \\
\text { Stropharia }\end{array}$ & $(\mathrm{M})$ & - & - & - & 1 & - & - & 3 & 1 & 2 & - & - & - & 7 \\
\hline semiglobata & $(\mathrm{L})$ & 1 & - & 2 & - & - & - & 3 & - & - & 1 & - & - & 7 \\
\hline Tricholoma sp. & (M) & 2 & - & 1 & - & - & - & 4 & - & - & - & - & - & 7 \\
\hline $\begin{array}{l}\text { T. flavovirens } \\
\text { Psathyrella }\end{array}$ & (M) & 7 & - & - & - & - & - & - & - & - & - & - & - & 7 \\
\hline candolleana & (L) & - & 2 & 1 & 1 & - & - & - & 1 & - & - & 1 & - & 6 \\
\hline Mycena viscosa & (W) & 1 & - & - & 1 & 2 & 2 & - & - & - & - & - & - & 6 \\
\hline Omphalina oniscus & (L) & - & 2 & 1 & - & 1 & - & - & - & - & - & 2 & - & 6 \\
\hline Hygrophorus sp. & (M) & 3 & 1 & 2 & - & - & - & - & - & - & - & - & - & 6 \\
\hline Mycena metata & (L) & 1 & - & - & 3 & - & - & 2 & - & - & - & - & - & 6 \\
\hline $\begin{array}{l}\text { Suillus bovinus } \\
\text { Strobilurus }\end{array}$ & (M) & 3 & - & - & 2 & - & - & - & - & 1 & - & - & - & 6 \\
\hline $\begin{array}{l}\text { esculentus } \\
\text { Lyophyllum }\end{array}$ & (L) & - & 2 & - & - & 4 & - & - & - & - & - & - & - & 6 \\
\hline $\begin{array}{l}\text { palustre } \\
\text { Amanita }\end{array}$ & (L) & - & 4 & - & - & - & - & - & 2 & - & - & - & - & 6 \\
\hline porphyria & (M) & - & - & 2 & - & 1 & 1 & - & - & 1 & - & - & - & 5 \\
\hline Pholiota mixta & (L) & 2 & - & - & - & - & - & - & - & - & 2 & - & 1 & 5 \\
\hline
\end{tabular}


Table 14. contnd.

\begin{tabular}{|c|c|c|c|c|c|c|c|c|c|c|c|c|c|c|}
\hline \multirow[t]{3}{*}{ Macrofungi } & \multirow[b]{3}{*}{$\mathrm{n}=$} & \multicolumn{3}{|c|}{1981} & \multicolumn{3}{|c|}{1982} & \multicolumn{3}{|c|}{1983} & \multicolumn{3}{|c|}{1984} & \multirow{3}{*}{$\begin{array}{l}\text { Total } \\
\text { fr. }\end{array}$} \\
\hline & & $\mathrm{F}$ & $\mathrm{P}$ & $\mathrm{F}+\mathrm{P}$ & $\mathrm{F}$ & & $\mathrm{F}+\mathrm{P}$ & $\mathrm{F}$ & & $\mathrm{F}+\mathrm{P}$ & $\mathrm{F}$ & & $\mathrm{F}+\mathrm{P}$ & \\
\hline & & 34 & 27 & 18 & 69 & 53 & 14 & 100 & 70 & 22 & 100 & 65 & 24 & \\
\hline \multicolumn{15}{|l|}{ Hygrophoropsis } \\
\hline $\begin{array}{l}\text { aurantiaca } \\
\text { Hebeloma }\end{array}$ & $(W)$ & - & - & - & 1 & - & - & 2 & - & - & 2 & - & - & 5 \\
\hline longicaudum & $(\mathrm{M})$ & - & 5 & - & - & - & - & - & - & - & - & - & - & 5 \\
\hline Suillus luteus & (M) & - & - & - & - & - & - & 1 & 1 & - & 1 & 1 & - & 4 \\
\hline $\begin{array}{l}\text { Gomphidius roseus } \\
\text { Kuehneromyces }\end{array}$ & (M & - & - & - & - & - & 1 & - & 1 & - & 1 & 1 & - & 4 \\
\hline $\begin{array}{l}\text { mutabilis } \\
\text { Lactarius }\end{array}$ & (W) & - & - & 1 & - & 1 & - & 1 & 1 & - & - & - & - & 4 \\
\hline torminosus & $(\mathrm{M})$ & 1 & - & - & - & 1 & - & 1 & - & 1 & - & - & - & 4 \\
\hline Russula consobrina & (M) & - & 1 & - & - & - & - & 2 & 1 & - & - & - & - & 4 \\
\hline Panellus serotinus & (W) & 3 & - & 1 & - & - & - & - & - & - & - & - & - & 4 \\
\hline Phaeocollybia sp. & (W) & 1 & - & 3 & - & - & - & - & - & - & - & - & - & 4 \\
\hline Pholiota flammans & (W) & - & 3 & 1 & - & - & - & - & - & - & - & - & - & 4 \\
\hline $\begin{array}{l}\text { Baespora myosura } \\
\text { Hygrophorus }\end{array}$ & (L) & 3 & - & - & - & - & - & 1 & - & - & - & - & - & 4 \\
\hline $\begin{array}{l}\text { hypothejus } \\
\text { Gomphidius }\end{array}$ & $(\mathrm{M})$ & 3 & - & - & - & - & - & - & 1 & - & - & - & - & 4 \\
\hline $\begin{array}{l}\text { glutinosus } \\
\text { Cortinarius }\end{array}$ & (M) & 1 & - & - & - & - & - & 1 & 1 & - & - & - & - & 3 \\
\hline $\begin{array}{l}\text { camphoratus } \\
\text { Marasmius }\end{array}$ & (M) & 1 & - & 1 & - & - & - & - & - & - & - & 1 & - & 3 \\
\hline epiphyllus & $(\mathrm{L})$ & 1 & 1 & - & - & - & - & - & - & - & - & 1 & - & 3 \\
\hline Tricholoma fulvum & (M) & 1 & 1 & 1 & - & - & - & - & - & - & - & - & - & 3 \\
\hline $\begin{array}{l}\text { Coprinus sp. } \\
\text { Cortinarius }\end{array}$ & (L) & 2 & 1 & - & - & - & - & - & - & - & - & - & - & 3 \\
\hline $\begin{array}{l}\text { hemitrichus } \\
\text { Hypholoma }\end{array}$ & $(\mathrm{M})$ & - & 2 & 1 & - & - & - & - & - & - & - & - & - & 3 \\
\hline lateritium & $(W)$ & - & 1 & 2 & - & - & - & - & - & - & - & - & - & 3 \\
\hline Inocybe lacera & (M) & 2 & - & 1 & - & - & - & - & - & - & - & - & - & 3 \\
\hline Laccaria proxima & (M) & - & - & - & 1 & - & - & 2 & - & - & - & - & - & 3 \\
\hline Mycena laevigata & (W) & 1 & - & - & 2 & - & - & - & - & - & - & - & - & 3 \\
\hline M. stipata & (W) & - & - & - & 1 & - & - & 2 & - & - & - & - & - & 3 \\
\hline Russula aeruginea & (M) & 2 & - & - & - & - & - & - & - & 1 & - & - & - & 3 \\
\hline R. gracillima & (M) & - & - & - & - & - & - & 1 & - & - & 2 & - & - & 3 \\
\hline Suillus flavidus & (M) & - & 1 & - & - & - & - & - & 2 & - & - & - & - & 3 \\
\hline Coprinus radiatus & (L) & 2 & - & 1 & - & - & - & - & - & - & - & - & - & 3 \\
\hline $\begin{array}{l}\text { Collybia confluens } \\
\text { Cortinarius }\end{array}$ & (L) & - & 1 & - & - & - & - & - & - & 1 & - & - & - & 2 \\
\hline delibutus & (M) & 1 & - & - & - & 1 & - & - & - & - & - & - & - & 2 \\
\hline C. triumphans & (M) & 1 & - & 1 & - & - & - & - & - & - & - & - & - & 2 \\
\hline $\begin{array}{l}\text { C. obtusus } \\
\text { Hygrophoropsis }\end{array}$ & (M) & 1 & 1 & - & - & - & - & - & - & - & - & - & - & 2 \\
\hline olida & $(\mathrm{L})$ & - & - & 1 & - & - & - & 1 & - & - & - & - & - & 2 \\
\hline Lactarius necator & (M) & - & - & - & - & - & 1 & - & 1 & - & - & - & - & 2 \\
\hline $\begin{array}{l}\text { Lepiota clypeolaria } \\
\text { Lyophyllum }\end{array}$ & (L) & 1 & - & 1 & - & - & - & - & - & - & - & - & - & 2 \\
\hline $\begin{array}{l}\text { fumosum } \\
\text { Megacollybia }\end{array}$ & (L) & - & - & - & 1 & - & - & 1 & - & - & - & - & - & 2 \\
\hline platyphylla & (W) & 1 & 1 & - & - & - & - & - & - & - & - & - & - & 2 \\
\hline Mycena flavoalba & (L) & - & - & - & - & - & - & 1 & - & - & 1 & - & - & 2 \\
\hline Psathyrella sp. & (L) & - & - & 1 & - & - & - & 1 & - & - & - & - & - & 2 \\
\hline Omphalina fibula & (L) & 1 & 1 & - & - & - & - & - & - & - & - & - & - & 2 \\
\hline Russula betularum & $(\mathrm{M})$ & - & - & - & - & - & - & 1 & - & - & 1 & - & $\begin{array}{l}- \\
\text { (cont }\end{array}$ & $\begin{array}{l}2 \\
\text { d.) }\end{array}$ \\
\hline
\end{tabular}


Table 14. contnd.

\begin{tabular}{|c|c|c|c|c|c|c|c|c|c|c|c|c|c|c|}
\hline \multirow[t]{3}{*}{ Macrofungi } & \multirow[b]{3}{*}{$\mathrm{n}=$} & \multicolumn{3}{|c|}{1981} & \multicolumn{3}{|c|}{1982} & \multicolumn{3}{|c|}{1983} & \multicolumn{3}{|c|}{1984} & \multirow{3}{*}{$\begin{array}{l}\text { Total } \\
\text { fr. }\end{array}$} \\
\hline & & $\mathrm{F}$ & $\mathrm{P}$ & $\mathrm{F}+\mathrm{P}$ & $\mathrm{F}$ & & $\mathrm{F}+\mathrm{P}$ & $\mathrm{F}$ & & $\mathrm{F}+\mathrm{P}$ & $\mathrm{F}$ & $\mathrm{P}$ & $\mathrm{F}+\mathrm{P}$ & \\
\hline & & 34 & 27 & 18 & 69 & 53 & 14 & 100 & 70 & 22 & 100 & 65 & 24 & \\
\hline $\begin{array}{l}\text { R. rhodopoda } \\
\text { Tricholoma }\end{array}$ & (M) & 1 & - & 1 & - & - & - & - & - & - & - & - & - & 2 \\
\hline $\begin{array}{l}\text { virgatum } \\
\text { Tricholomopsis }\end{array}$ & (M) & - & - & 1 & - & - & - & 1 & - & - & - & - & - & 2 \\
\hline rutilans & $(W)$ & - & - & 1 & - & - & - & - & - & - & 1 & - & - & 2 \\
\hline $\begin{array}{l}\text { Tubaria confragosa } \\
\text { Lentinellus }\end{array}$ & (W) & 1 & 1 & - & - & - & - & - & - & - & - & - & - & 2 \\
\hline cochleatus & (W) & 1 & - & - & - & - & - & 1 & - & - & - & - & - & 2 \\
\hline $\begin{array}{l}\text { L. omphalodes } \\
\text { Tricholoma }\end{array}$ & (W) & 1 & - & 1 & - & - & - & - & - & - & - & - & - & 2 \\
\hline inamoenum & (M) & - & - & - & - & - & - & 1 & - & 1 & - & - & - & 2 \\
\hline Clitocybe diatreta & (L) & 2 & - & - & - & - & - & - & - & - & - & - & - & 2 \\
\hline $\begin{array}{l}\text { C. candicans } \\
\text { Hygrophorus }\end{array}$ & (L) & - & - & 2 & - & - & - & - & - & - & - & - & - & 2 \\
\hline korhonenii & (M) & - & - & 2 & - & - & - & - & - & - & - & - & - & 2 \\
\hline Laccaria bicolor & (M) & - & - & 2 & - & - & - & - & - & - & - & - & - & 2 \\
\hline $\begin{array}{l}\text { Lactarius musteus } \\
\text { Leccinum }\end{array}$ & (M) & - & - & - & - & - & - & - & - & - & 2 & - & - & 2 \\
\hline $\begin{array}{l}\text { aurantiacum } \\
\text { Paxillus }\end{array}$ & (M) & - & - & - & - & - & - & - & - & 2 & - & - & - & 2 \\
\hline atrotomentosus & $(W)$ & 2 & - & - & - & - & - & - & - & - & - & - & - & 2 \\
\hline $\begin{array}{l}\text { Lyophyllum sp. } \\
\text { Strobilurus }\end{array}$ & (L) & 2 & - & - & - & - & - & - & - & - & - & - & - & 2 \\
\hline stephanocystis & $(\mathrm{L})$ & - & - & - & 2 & - & - & - & - & - & - & - & - & 2 \\
\hline Boletus edulis & (M) & 1 & - & - & - & - & - & - & - & - & - & - & - & 1 \\
\hline B. pinophilus & (M) & 1 & - & - & - & - & - & - & - & - & - & - & - & 1 \\
\hline Coprinus cinereus & (L) & 1 & - & - & - & - & - & - & - & - & - & - & - & 1 \\
\hline Cortinarius flexipes & (M) & 1 & - & - & - & - & - & - & - & - & - & - & - & 1 \\
\hline C. trivialis & (M) & 1 & - & - & - & - & - & - & - & - & - & - & - & 1 \\
\hline C. laniger & (M) & 1 & - & - & - & - & - & - & - & - & - & - & - & 1 \\
\hline C. paleaceus & (M) & 1 & - & - & - & - & - & - & - & - & - & - & - & 1 \\
\hline $\begin{array}{l}\text { C. evernius } \\
\text { Cyphellostereum }\end{array}$ & (M) & 1 & - & - & - & - & - & - & - & - & - & - & - & 1 \\
\hline laeve & (L) & 1 & - & - & - & - & - & - & - & - & - & - & - & 1 \\
\hline $\begin{array}{l}\text { Entoloma nitidum } \\
\text { Hohenbuehelia }\end{array}$ & (L) & 1 & - & - & - & - & - & - & - & - & - & - & - & 1 \\
\hline petaloides & $(\mathrm{L})$ & 1 & - & - & - & - & - & - & - & - & - & - & - & 1 \\
\hline Hygrophorus piceae & (M) & 1 & - & - & - & - & - & - & - & - & - & - & - & 1 \\
\hline Panus conchatus & (W) & 1 & - & - & - & - & - & - & - & - & - & - & - & 1 \\
\hline Pluteus sp. & (W & 1 & - & - & - & - & - & - & - & - & - & - & - & 1 \\
\hline $\begin{array}{l}\text { Polyporus varius } \\
\text { Stropharia }\end{array}$ & (W) & 1 & - & - & - & - & - & - & - & - & - & - & - & 1 \\
\hline aeruginosa & (L) & 1 & - & - & - & - & - & - & - & - & - & - & - & 1 \\
\hline Psilocybe sp. & (L) & 1 & - & - & - & - & - & - & - & - & - & - & - & 1 \\
\hline Melanoleuca sp. & (L) & - & - & - & 1 & - & - & - & - & - & - & - & - & 1 \\
\hline $\begin{array}{l}\text { Mycena urania } \\
\text { Hygrophorus }\end{array}$ & (L) & - & - & - & 1 & - & - & - & - & - & - & - & - & 1 \\
\hline $\begin{array}{l}\text { karstenii } \\
\text { Tricholoma }\end{array}$ & $(\mathrm{M})$ & - & - & - & 1 & - & - & - & - & - & - & - & - & 1 \\
\hline pessundatum & (M) & - & - & - & 1 & - & - & - & - & - & - & - & - & 1 \\
\hline $\begin{array}{l}\text { Collybia maculata } \\
\text { Cystoderma }\end{array}$ & (L) & - & - & - & - & - & - & 1 & - & - & - & - & - & 1 \\
\hline carcharias & (L) & - & - & - & - & - & - & 1 & - & - & - & - & - & 1 \\
\hline Russula vesca & (M) & - & - & - & - & - & - & 1 & - & - & - & - & - & 1 \\
\hline
\end{tabular}


Table 14. contnd.

\begin{tabular}{|c|c|c|c|c|c|c|c|c|c|c|c|c|c|c|}
\hline \multirow[t]{3}{*}{ Macrofungi } & \multirow[b]{3}{*}{$\mathrm{n}=$} & \multicolumn{3}{|c|}{1981} & \multicolumn{3}{|c|}{1982} & \multicolumn{3}{|c|}{1983} & \multicolumn{3}{|c|}{1984} & \multirow{3}{*}{$\begin{array}{l}\text { Total } \\
\text { fr. }\end{array}$} \\
\hline & & $\mathrm{F}$ & $\mathrm{P}$ & $\mathrm{F}+\mathrm{P}$ & $\mathrm{F}$ & $\mathrm{P}$ & $\mathrm{F}+\mathrm{P}$ & $\mathrm{F}$ & $\mathrm{P}$ & $\mathrm{F}+\mathrm{P}$ & $\mathrm{F}$ & $\mathrm{P}$ & $\mathrm{F}+\mathrm{P}$ & \\
\hline & & 34 & 27 & 18 & 69 & 53 & 14 & 100 & 70 & 22 & 100 & 65 & 24 & \\
\hline R. adusta & $(\mathrm{M})$ & - & - & - & - & - & - & 1 & - & - & - & - & - & 1 \\
\hline Clitocybe gibba & (L) & - & - & - & - & - & - & 1 & - & - & - & - & - & 1 \\
\hline C. fragrans & (L) & - & - & - & - & - & - & 1 & - & - & - & - & - & 1 \\
\hline Cortinarius bolaris & (M) & - & - & - & - & - & - & 1 & - & - & - & - & - & 1 \\
\hline $\begin{array}{l}\text { Lentinus lepideus } \\
\text { Psilocybe }\end{array}$ & (W) & - & - & - & - & - & - & 1 & - & - & - & - & - & 1 \\
\hline $\begin{array}{l}\text { magnivelaris } \\
\text { Tricholoma }\end{array}$ & $(\mathrm{L})$ & - & - & - & - & - & - & 1 & - & - & - & - & - & 1 \\
\hline aestuans & (M) & - & - & - & - & - & - & 1 & - & - & - & - & - & 1 \\
\hline T. album & (M) & - & - & - & - & - & - & 1 & - & - & - & - & - & 1 \\
\hline $\begin{array}{l}\text { Amanita muscaria } \\
\text { Omphaliaster }\end{array}$ & M) & - & - & - & - & - & - & 1 & - & - & - & - & - & 1 \\
\hline borealis & $(\mathrm{L})$ & - & - & - & - & - & - & 1 & - & - & - & - & - & 1 \\
\hline $\begin{array}{l}\text { Amanita regalis } \\
\text { Chalciporus }\end{array}$ & (M) & - & - & - & - & - & - & - & - & - & 1 & - & - & 1 \\
\hline $\begin{array}{l}\text { piperatus } \\
\text { Hygrophorus }\end{array}$ & (M) & - & - & - & - & - & - & - & - & - & 1 & - & - & 1 \\
\hline $\begin{array}{l}\text { pustulatus } \\
\text { Tricholoma }\end{array}$ & $(\mathrm{M})$ & - & - & - & - & - & - & - & - & - & 1 & - & - & 1 \\
\hline nauseosum & (M) & - & - & - & - & - & - & - & - & - & 1 & - & - & 1 \\
\hline $\begin{array}{l}\text { T. portentosum } \\
\text { Tricholomopsis }\end{array}$ & $(\mathrm{M})$ & - & - & - & - & - & - & - & - & - & 1 & - & - & 1 \\
\hline $\begin{array}{l}\text { decora } \\
\text { Cortinarius }\end{array}$ & $(W)$ & - & - & - & - & - & - & - & - & - & 1 & - & - & 1 \\
\hline $\begin{array}{l}\text { vibratilis } \\
\text { Galerina hypnorum }\end{array}$ & (M) & - & 1 & - & - & - & - & - & - & - & - & - & - & 1 \\
\hline $\begin{array}{l}\text { s. lat. } \\
\text { Hypholoma }\end{array}$ & (W) & - & 1 & - & - & - & - & - & - & - & - & - & - & 1 \\
\hline $\begin{array}{l}\text { myosotis } \\
\text { Lactarius }\end{array}$ & (L) & - & 1 & - & - & - & - & - & - & - & - & - & - & 1 \\
\hline camphoratus & (M) & - & 1 & - & - & - & - & - & - & - & - & - & - & 1 \\
\hline Mycena cinerella & (L) & - & 1 & - & - & - & - & - & - & - & - & - & - & 1 \\
\hline Pholiota alnicola & (W) & - & 1 & - & - & - & - & - & - & - & - & - & - & 1 \\
\hline $\begin{array}{l}\text { P. scamba } \\
\text { Galerina } \mathrm{cf} \text {. }\end{array}$ & (W) & - & 1 & - & - & - & - & - & - & - & - & - & - & 1 \\
\hline sphagnorum & $(\mathrm{L})$ & - & - & - & - & 1 & - & - & - & - & - & - & - & 1 \\
\hline Lactarius uvidus & (M) & - & - & - & - & 1 & - & - & - & - & - & - & - & 1 \\
\hline $\begin{array}{l}\text { Fayodia maura } \\
\text { Hebeloma }\end{array}$ & (L) & - & - & - & - & - & - & - & 1 & - & - & - & - & 1 \\
\hline $\begin{array}{l}\text { crustuliniforme } \\
\text { Lactarius }\end{array}$ & $(\mathrm{M})$ & - & - & - & - & - & - & - & 1 & - & - & - & - & 1 \\
\hline deterrimus & (M) & - & - & - & - & - & - & - & 1 & - & - & - & - & 1 \\
\hline L. scrobiculatus & (M) & - & - & - & - & - & - & - & 1 & - & - & - & - & 1 \\
\hline Amanita virosa & (M) & - & - & - & - & - & - & - & - & - & - & 1 & - & 1 \\
\hline $\begin{array}{l}\text { Agrocybe sp. } \\
\text { Cortinarius }\end{array}$ & (L) & - & - & 1 & - & - & - & - & - & - & - & - & - & 1 \\
\hline $\begin{array}{l}\text { anomalus } \\
\text { Pluteus }\end{array}$ & $(\mathrm{M})$ & - & - & 1 & - & - & - & - & - & - & - & - & - & 1 \\
\hline atricapillus & $(\mathrm{W})$ & - & - & 1 & - & - & - & - & - & - & - & - & - & 1 \\
\hline Russula foetens & (M) & - & - & 1 & - & - & - & - & - & - & - & - & - & 1 \\
\hline $\begin{array}{l}\text { Naucoria sp. } \\
\text { Flammulina }\end{array}$ & (M) & - & - & 1 & - & - & - & - & - & - & - & - & - & 1 \\
\hline velutipes & $(\mathrm{W})$ & - & - & 1 & - & - & - & - & - & - & - & - & - & 1 \\
\hline
\end{tabular}


Table 14. contnd.

\begin{tabular}{|c|c|c|c|c|c|c|c|c|c|c|c|c|c|c|}
\hline \multirow[t]{3}{*}{ Macrofungi } & \multirow[b]{3}{*}{$\mathrm{n}=$} & \multirow{3}{*}{$\begin{array}{l}\text { F } \\
34\end{array}$} & \multicolumn{2}{|l|}{1981} & \multirow[b]{2}{*}{$\mathrm{F}$} & \multicolumn{2}{|l|}{1982} & \multirow[b]{2}{*}{$\mathrm{F}$} & \multicolumn{2}{|l|}{1983} & \multirow[b]{2}{*}{$\mathrm{F}$} & \multicolumn{2}{|c|}{1984} & \multirow{3}{*}{$\begin{array}{l}\text { Tota } \\
\text { fr. }\end{array}$} \\
\hline & & & $\mathrm{P}$ & $\mathrm{F}+\mathrm{P}$ & & $\mathrm{P}$ & $\mathrm{F}+\mathrm{P}$ & & $\mathrm{P}$ & $\mathrm{F}+\mathrm{P}$ & & $\mathrm{P}$ & $\mathrm{F}+\mathrm{P}$ & \\
\hline & & & 27 & 18 & 69 & 53 & 14 & 100 & 70 & 22 & 100 & 65 & 24 & \\
\hline \multicolumn{15}{|l|}{ Hygrophorus } \\
\hline agathosmus & (M) & - & - & - & - & - & 1 & - & - & - & - & - & - & 1 \\
\hline Clitocybe ditopus & (L) & - & - & - & - & - & 1 & - & - & - & - & - & - & 1 \\
\hline Xeromphalia fellea & (L) & - & - & - & - & - & 1 & - & - & - & - & - & - & 1 \\
\hline Collybia acervata & (W) & - & - & - & - & - & - & - & - & 1 & - & - & - & 1 \\
\hline Tylopilus felleus & (M) & - & - & - & - & - & - & - & - & - & - & - & 1 & 1 \\
\hline Mycorrhizal species & & $\begin{array}{l}64 \\
46.4\end{array}$ & $\begin{array}{l}46 \\
43.4\end{array}$ & $\begin{array}{l}56 \\
46.3\end{array}$ & $\begin{array}{l}30 \\
42.9\end{array}$ & $\begin{array}{l}33 \\
\mathbf{5 5 . 9}\end{array}$ & $\begin{array}{l}17 \\
\mathbf{5 1 . 5}\end{array}$ & $\begin{array}{l}58 \\
\mathbf{5 0 . 4}\end{array}$ & $\begin{array}{l}48 \\
\mathbf{5 7 . 1}\end{array}$ & $\begin{array}{l}38 \\
66.7\end{array}$ & $\begin{array}{l}37 \\
\mathbf{5 9 . 7}\end{array}$ & $\begin{array}{l}37 \\
63.8\end{array}$ & $\begin{array}{l}22 \\
75.9\end{array}$ & \\
\hline Litter saprophytes & & $\begin{array}{l}50 \\
36.2\end{array}$ & $\begin{array}{l}42 \\
39.6\end{array}$ & $\begin{array}{l}44 \\
36.4\end{array}$ & $\begin{array}{l}28 \\
\mathbf{4 0 . 0}\end{array}$ & $\begin{array}{l}23 \\
\mathbf{3 9 . 0}\end{array}$ & $\begin{array}{l}12 \\
36.4\end{array}$ & $\begin{array}{l}43 \\
37.4\end{array}$ & $\begin{array}{l}30 \\
35.7\end{array}$ & $\begin{array}{l}16 \\
28.1\end{array}$ & $\begin{array}{l}18 \\
29.0\end{array}$ & $\begin{array}{l}18 \\
31.0\end{array}$ & $\begin{array}{c}7 \\
24.1\end{array}$ & \\
\hline Wood saprophytes & & $\begin{array}{l}23 \\
16.7\end{array}$ & $\begin{array}{l}17 \\
\mathbf{1 6 . 0}\end{array}$ & $\begin{array}{l}20 \\
16.5\end{array}$ & $\begin{array}{l}12 \\
17.1\end{array}$ & $\begin{array}{l}3 \\
5.1\end{array}$ & $\begin{array}{l}3 \\
9.1\end{array}$ & $\begin{array}{l}13 \\
\mathbf{1 1 . 3}\end{array}$ & $\begin{array}{l}6 \\
7.2\end{array}$ & $\begin{array}{l}3 \\
5.2\end{array}$ & $\begin{array}{l}7 \\
11.3\end{array}$ & $\begin{array}{l}3 \\
5.2\end{array}$ & $\begin{array}{l}- \\
-\end{array}$ & \\
\hline Parasites & & $\begin{array}{l}1 \\
0.7\end{array}$ & $\begin{array}{l}1 \\
\mathbf{1 . 0}\end{array}$ & $\begin{array}{l}1 \\
0.8\end{array}$ & - & - & $\begin{array}{l}1 \\
3.0\end{array}$ & $\begin{array}{l}1 \\
0.8\end{array}$ & - & - & - & - & - & \\
\hline $\begin{array}{l}\text { Total number of } \\
\text { macrofungi }\end{array}$ & & 138 & 106 & 121 & 70 & 59 & 33 & 115 & 84 & 57 & 62 & 58 & 29 & \\
\hline
\end{tabular}

* Cortinarius spp. containing some species in the subgenus Telamonia

** Galerina spp. and Clitocybe spp. two or three different species

types in 1981-1984. Ninety-five macrofungus species were identified in only one or two sample plots (Table 14). The percentages of mycorrhizal species, litter and wood saprophytes and parasites in mineral soil forest, peatland and mixed forest and peatland site types are given in Table 14.

The good mushroom yield of 1981 is indicated by the observations that all the inventoried sample plots $(n=79)$ had macrofungus species (on most of the sample plots, the number of species identified exceeded 10). In the poor mushroom yield year of 1982, inventories covered 136 sample plots; 21 plots had no macrofungi and 53 sample plots had only three species present, or less. During the middling year of $1983(\mathrm{n}=192)$, thirteen sample plots were void of macrofungi. The species composition study conducted in 1984 as a single inventory (n $=189$ ) revealed 65 sample plots void of macrofungi; of these, 36 sample plots represented heath forest sites. The great number of sample plots void of macrofungi was the result of dry weather at the beginning of the growing season in MayJune.

\section{Discussion}

Diversity of macrofungus communities and composition of ecological groups

The sampling method used here, whereby sampling is made from square-shaped permanent mycoflora sample plots (each 0.01 ha in size) located inside the inventory blocks used in the National Forest Inventory, involves systematic sampling. For the purposes of this study, the species of fungus collected from a permanent plot 0.01 ha in size provided an adequate picture of the occurrence of fungal communities during the study years, especially with regard to mesic $(n=111)$, dryish $(n=143)$ and dry $(n=47)$ heath forests. The macrofungi of the most nutrientpoor drained sites of varying ages of pine mires and bogs $(n=149)$ and spruce mires $(n=50)$ differed from one another and from the macrofungi of virgin mire sites (total of 55 sample plots). The study material had a fairly low number of forest and peatland site types defined as fertile on the basis of their vegetation. The plant flora in rich heath forests and mires characterised by an abundance of herbs, tall 
sedges and Vaccinium myrtillus (incl. drained sites) was more versatile than in the poorest forest and peatland site types; thus, the fertility of the sample plots at least enhances the chances for the occurrence of saprophytic fungi.

Podsol soil types typically exhibit an acidic raw humus layer ( $\mathrm{pH} \mathrm{c.} \mathrm{4)} \mathrm{overlaying} \mathrm{the} \mathrm{uppermost}$ (leached) layer of mineral soil, the said humus layer being composed of the densely interwoven roots of dwarf shrubs and other plants so that it has a felt-like appearance. Many saprophytic fungi acting upon the raw humus and litter inhabit this slowly decomposing moss and litter layer, the A 1 horizon. Saprophytes feeding on forest mosses can also be referred to as conditional saprophytes acting upon the raw humus layer. The substrate of most mycorrhizal fungi consists of the acidic raw humus layer, which lacks (or contains only small populations of) earthworms, bacteria and protozoa, these being more abundant in the less acidic mull soil.

The commonest soil class was that of loams and moraine. Sorted material was present on only a few sample plots. In 1990, to meet the needs of the present study, soil and peat samples were taken from more than 100 sample plots, which were analysed for the main nutrients and their $\mathrm{pH}$ (unpublished material). Mineral soil and peatland site samples totalling 194 were analysed; the average $\mathrm{pH}$ was 4.18 (range of variation 3.70 4.79). Thus, the soil-based macrofungi on the forest and peatland site types appeared to be mainly of the acidophilic kind.

Some study results are compared to those of earlier European studies (Table 15). The ecological groupings in those studies differ from those used here: The high percentage of terrestial fungi (soil fungi) in evergreen oak woods (Quercus ilex woods) is caused by the way such woods are managed (cuttings are carried out every 12-14 years) and particularly by the type of litter produced (De Dominicis \& Barluzzi 1983) (Table 15). In actual fact, Quercus ilex leaves fall in late spring, when they are two years old, and they remain on the ground for a long time, forming a thick and compact cover. Their humification proceeds slowly and only in the layer at the ground surface, as the top layer protects the soil from evaporation and rapid temperature changes. The ecological conditions are favourable for the production of terrestrial fungi (soil fungi) but unfavourable for the development of litter fungi (De Dominicis \& Barluzzi 1983).
In hemiboreal coniferous and decidious forests the percentage of terrestial fungi (if mycorrhizal species and litter saprophytes are combined) is almost the same (83.9\%) as in evergreen oak woods $(84.5 \%)$, but lower $(65.3 \%)$ than in boreal coniferous and mixed forests and peatlands (Table 15).

The macrofungi of chestnut forests is very different from that of oak forests. It is characterised by a large admixture of acidophilous species, some of which also occur in coniferous forests (Tortić \& Lisiewska 1978). It is astonishing to note that many macrofungi are common to both chestnut forests (and acidophilous beech and oak forests) and the coniferous forests of North Karelia, Finland. Examples include Amanita fulva, A. muscaria, A. vaginata, Boletus edulis, Cantharellus cibarius, $C$. tubaeformis, Cortinarius muscigenus, C. trivialis, Laccaria laccata, Paxillus involutus, Russula foetens, $R$. xerampelina, Lactarius camphoratus, $L$. uvidus and Tylopilus felleus, most of which are mycorrhizal species of Norway spruce and birch (Table 4). All mycorrhizal species mentioned above can live in symbiosis with Castanea vesca, Quercus petraea and Fagus silvatica, the main tree species in chestnut forests (Tortić \& Lisiewska 1978).

Kalamees (1980b) describes 735 macrofungi encountered on various sites in Estonia. Although the overall variety of macrofungi reported by Kalamees was clearly larger than in this study, the relative proportion of mycorrhizal species and parasites was nearly the same (Table 15). In the present study, wood saprophytes amounted to $32.6 \%$, whereas Kalamees obtained a figure of $15.1 \%$ (Table 15). The explanation for this significant difference is that the figures for the present study (in addition to macrofungi) include 61 species of fungi belonging to the orders Aphyllophorales, Heterobasidiomycetes and Gasteromycetes and 23 Ascomycotina fungi not included in the study by Kalamees (1980b).

The number of saprophyte species was notably high in the study of Kalamees (1980b) (Table 15). The reason for this is that some of Estonia's mineral soils support a high variety of tree and shrub flora, and fertile forest types have an abundance of grasses and herbs. The litter is more versatile both qualitatively and quantitatively, and it is decomposed by a richer flora of saprophytes than can be maintained nutrient-poor heath forests of Karelia and their acidophilic saprophyte flora. In addition to forest and peatland types, in his study 
Table 15. Number of fungi and percentage of the ecological groups in some deciduous forests of southern and central Europe, in the hemiboreal forest zone of Estonia and in the boreal coniferous forest zone of Finland. $M=$ mycorrhizal species, $S=$ soil fungi incl. both saprophytic and mycorrhizal species, $\mathrm{L}=$ litter saprophytes incl. humus saprophytes, saprophytes on mosses and peat, on an organic base in mineral soil or burnt ground and fungal and herbivore dung, $\mathrm{W}=$ wood saprophytes and $\mathrm{P}$ $=$ parasites.

\begin{tabular}{|c|c|c|c|c|c|c|c|}
\hline Forests (woods) & $\begin{array}{l}\text { M } \\
\text { No of } \\
\text { fungi, } \\
\%\end{array}$ & $\begin{array}{l}\text { S } \\
\text { No of } \\
\text { fungi, } \\
\%\end{array}$ & $\begin{array}{l}\text { L } \\
\text { No of } \\
\text { fungi, } \\
\%\end{array}$ & $\begin{array}{l}\text { W } \\
\text { No of } \\
\text { fungi, } \\
\%\end{array}$ & $\begin{array}{l}\mathrm{P} \\
\text { No of } \\
\text { fungi, } \\
\%\end{array}$ & $\begin{array}{l}\text { Total } \\
\text { no of } \\
\text { fungi }\end{array}$ & Source \\
\hline Hornbeam oak woods & & $\begin{array}{l}237 \\
75.7\end{array}$ & $\begin{array}{l}48 \\
15.3\end{array}$ & $\begin{array}{l}23 \\
7.4\end{array}$ & $\begin{array}{l}5 \\
1.6\end{array}$ & 313 & Darimont (1973) \\
\hline Beech woods & & $\begin{array}{l}130 \\
\mathbf{4 9 . 0}\end{array}$ & $\begin{array}{l}69 \\
\mathbf{2 6 . 0}\end{array}$ & $\begin{array}{l}66 \\
24.9\end{array}$ & & 265 & Lisiewska (1974) \\
\hline Acid oak woods & $\begin{array}{l}102 \\
32.6\end{array}$ & & $\begin{array}{l}123 \\
39.3\end{array}$ & $\begin{array}{l}81 \\
25.9\end{array}$ & $\begin{array}{l}7 \\
2.2\end{array}$ & 313 & Jansen (1981) \\
\hline Evergreen oak woods & & $\begin{array}{l}153 \\
\mathbf{8 4 . 5}\end{array}$ & $\begin{array}{c}14 \\
7.7\end{array}$ & $\begin{array}{c}11 \\
6.1\end{array}$ & $\begin{array}{l}3 \\
1.7\end{array}$ & 181 & $\begin{array}{l}\text { De Dominicis \& } \\
\text { Barluzzi (1983) }\end{array}$ \\
\hline $\begin{array}{l}\text { Hemiboreal coniferous } \\
\text { and deciduous forests }\end{array}$ & $\begin{array}{l}285 \\
38.8\end{array}$ & & $\begin{array}{l}332 \\
45.1\end{array}$ & $\begin{array}{r}111 \\
\mathbf{1 5 . 1}\end{array}$ & $\begin{array}{l}7 \\
1.0\end{array}$ & 735 & $\begin{array}{l}\text { Kalamees } \\
(1980 b)\end{array}$ \\
\hline $\begin{array}{l}\text { Boreal coniferous and } \\
\text { mixed forests and } \\
\text { peatlands }\end{array}$ & $\begin{array}{l}125 \\
39.6\end{array}$ & & $\begin{array}{l}81 \\
25.6\end{array}$ & $\begin{array}{l}103 \\
32.6\end{array}$ & $\begin{array}{l}7 \\
2.2\end{array}$ & 316 & This study \\
\hline
\end{tabular}

Kalamees (1980b) included meadows on mineral soils (alvar meadows, moraine hill meadows, typical meadows) rich in humus and saprophytic macrofungi acting upon litter; yet abundant mycorrhizal macrofungi were also reported to occur on these meadows (Kalamees 1980a).

Mycorrhizal species are generally easy to distinguish; i.e. species of genera such as Boletus, Lactarius, Leccinum, Cortinarius, Russula, Suillus and Tricholoma are beyond doubt. Species of some genera, such as Bankera, Hydnellum, Hydnum, Phellodon and Sarcodon, have been presented as saprophytic species (Maas Geesteranus 1975, Heiskanen \& Ohenoja 1986). Hintikka \& Näykki (1967) considered them to be mycorrhizal. Coltricia perennis and Scutiger spp. can be considered to be litter saprophytes. Alternatively, they may be seen as being mycorrhizal.

Wood saprophytes growing on trunks, branches, stumps of trees and rotten wood are easy to distinguish. It is readily noticed that deciduous trees are a more preferable substrate for wood saprophytes (46 species) than conifers (36 species) (Table 6). In this study the ratio of species is 1:0.8; according to Kalamees (1980b) the ratio is 1:0.5. A few macrofungi are wood saprophytes of both deciduous and coniferous trees; i.e. Gymnopilus penetrans, Hypholoma fasciculare, Mycena galericulata and Pluteus atricapillus.

It is not always easy to distinguish litter saprophytes from humus saprophytes. In the case of some species, it was difficult to determine whether the species grew in the humus or in the fallen leaves. This study rejected the idea that humus saprophytes form their own ecological group; instead a litter saprophytes group was formed which also contained saprophytes specializing in certain parts of the litter, and what may be referred to as humus saprophytes constitute one component of the litter saprophytes of conifers and deciduous trees (Table 7). Jansen (1981) formed both a humus saprophytes group - the species of the genera Clitocybe, Cystoderma, Entoloma, Psathyrella etc. - and a litter saprophytes group. As litter saprophytes, Jansen (1981) considered the species of the genera Ciboria, Clavariadelphus, Collybia (except $C$. fusipes), Marasmius, Psilocybe, Rickenella, 
Typhula and some of the species of the genera Galerina and Mycena.

The difference between parasites and saprophytes is not always clearly defined. Traditionally, Aphyllophorales species have been taken to form one family, Polyporaceae, and many genera of which are classified as being wood saprophytes. Nowadays, Tremellales, Aphyllophorales and Hymenochaetales species are divided into eleven families. Species of Coriolaceae and Poriaceae are real polyporus fungi (Niemelä 1988). In connection with the present study, Aphyllophorales species (Table 6) were considered to be wood saprophytes with the exception of Heterobasidion annosum, which is both a tree parasite and a wood saprophyte.

Many of the Aphyllophorales species kill living trees and also act as wood saprophytes. Fomes fomentarius, Inonotus obliquus and Piptoporus betulinus are parasites and wood saprophytes on birches, Phellinus conchatus on living and dead willows, $P$. igniarius on all deciduous trees (seldom on aspen); $P$. pini is a parasite and secondarily a wood saprophyte of Scots pine and $P$. tremulae is a parasite of living aspens (Niemelä 1988). The spores of most heartwood-decaying polyporus fungi gain entry into the wood or under the bark through stem and root injuries, through broken branches and through passages made bark beetles. Castello et al. (1976) mention Fomitopsis pinicola as an example of the last mentioned route of entry; this polyporus fungus is a common saprophyte of conifer wood, and it is the cause of considerable economic losses (Niemelä 1988).

Lyophyllum palustre and Galerina paludosa were considered to be moss saprophytes living on Sphagnum species (Table 8) and Cystoderma species litter saprophytes depending on the litter of coniferous and deciduous tree species (Table 7). According to Untiedt \& Müller (1985), Lyophyllum palustre is a parasite, because its mycelium can penetrate through plant cell walls and decompose the contents cells; the cell walls are, however, left intact. Afflicted Sphagnum mosses die in a few days, and saprophytic species then begin commence to decompose the surroundings of the fruit body, whereupon a light-coloured spot appears on the Sphagnum moss. Galerina paludosa infects the cells of the protonema and absorbs nutrients from it (Redheard 1981). Cystoderma species can de-compose the base of dead mosses or, alternatively, Cystoderma species can live in symbiosis with mosses and they can be parasites of forest mosses (Harmaja \& Korhonen 1991).

Ordination and classification methods of macrofungi

The macrofungus material for the year $1981 \mathrm{did}$ not include sample plots containing only one or two species that would have made it necessary to exclude the sample plot in question as a nonconforming observation. The ordination and classification methods that were applied required the presence of several fungus species on each sample plot. The classification method has previously been used in connection with plant material studies conducted in Finland (e.g. Oksanen 1984, Kuusipalo 1985, Sepponen 1985, Lahti \& Väisänen 1987, Tonteri et al. 1990); The problem of overly uniform material did not arise in those studies as the field and ground layers generally contain several plant species.

The material sampled in 1981 (mineral soil forest, peatland and mixed forest and peatland site types) provide supplementary data on the structure of mycocommunities. In a method that makes hierarchical divisions, the probability of obtaining a correct classification is highest with the first division, whereafter the probability decreases. Owing to the size of the material, the data obtained were defined using two divisional levels.

In the case of forest and peatland types resembling one another in terms of their macrofungi, the classification method appeared to work well, and the indicator species were members of the basic species forming the groups (Figs. 5 and 6). TWINSPAN classification highlighted the selectiveness of the program, as the mixed sample plots in the material for 1981 formed a heterogenic sample plot cluster of their own, thus making it possible to stratify the material into sample plots of forest and peatland site types and into mixed sample plots. In the mixed sample plots (e.g. 12VMT70\% + $42 \mathrm{RhK} 30 \%$ ), the macrofungi included species characteristic of heath forests and mires, and consequently the indicator species do not necessarily dominant species depicting the group.

Distributions made in connection with DCA analyses on the basis of vegetation cover analyses (\% coverage scale) are often askew, especially those for rare species. In addition, the distributions may have twin peaks, and 
consequently the frequencies of species rarely take on the form of a normal distribution. Many saprophytic fungi depend on a specific substrate, such as aspen leaves, spruce cones, elk dung or hare droppings. Random variation thus plays a significant role in the occurrence of many saprophytic fungi. Aspen leaves may be carried far inside a barren site where aspen as such does not occur. Similarly, a squirrel may carry a spruce cone from a GOMT sample plot to an ECT sample plot.

The sample plots grouped according to their plant species in the study by Salo (1979) formed six separate sample plot groups when viewed in six dimensions. Six sample plot groups were also formed when the material was examined according to species of fungi, but these groups were located closer to one another and were partly overlapping in the ordination space. This closeness and overlapping were due to differences in the composition of plant species on drained and fertilized Sphagnum fuscum pine bog sample plots, for instance (i.e. Pleurozium Calluna and Sphagnum fuscum - Calluna plant communities), whereas their macrofungi were the same. The sample plot group of virgin true dwarf-shrub pine bogs differed from the other peatland type sample plot groups in terms of both its plant and fungus flora (Salo 1979). The results obtained in the present study confirmed the consept that drained peatland site types (especially pine bogs) have a more versatile macrofungi than virgin mires (Salo 1979).

Virgin pine bog sample plots and a virgin ombrotrophic small sedge bog sample plot ( $\mathrm{LkN})$ had less fungus species in this study than did sites that had been recently drained or sites that were classified as being in the transitional stage following drainage. Drainage had improved the supply of oxygen to roots, and this was made evident by the improved height growth of pines and the increased number of species and occurrence of mycorrhizal fungi.

Jäppinen et al. (1986) used DCA analysis on VT and MT forest types when they grouped sample plots according to the species composition and the biomass of macrofungi. DCA analyses revealed that in a dry year, a mesic heath forest (MT) and a dryish heath forest (VT) resembled one another in terms of mushroom yield and species composition. In this study in the good mushroom yield year of 1981, sample plots representing a mesic heath forest (VMT) and a dryish heath forest (EVT) contained many of the same species of macrofungi, whereas mature mesic heath forests had a macrofungi differing both from that of younger forests of the same forest type and from that of dryish heath forest sample plots. The macrofungi in mature heath forests on mesic mineral soil sites are more versatile than the macrofungi in heath forests of younger development classes or in dryer heath forest soils, because the microclimate and the moister conditions of the ground layer are more favourable to the growth of saprophytic species than in forests with dryer soils and developmentally younger classes of trees.

According to Hintikka (1988), the number of basidiocarps in an oligotrophic pine forest reaches its peak in 20-year-old, relatively dense stands, being smaller in regeneration areas and over-aged stands. Stands known as pole stage stands had an average height of 4-9 $\mathrm{m}$ and a canopy density of 80-95\%; the dense tree stand presents favourable conditions for the growth of mycelia, because the humus and moss layers stay moist longer than in more open stands. In addition, the microclimate is less extreme with regard to frosts (Hintikka 1988). In normal mushroom years, the yields of macrofungi and the number of basidiocarps in oligotrophic young pine stands (pole-aged stands) can be high, though the number of mycorrhizal and saprophytic species is less than in mesotrophic pine and spruce forests (VMT).

The macrofungi of transitional drained spruce mire sites ( $\mathrm{KgKmu}, \mathrm{PKmu})$ and pine mire and bog sites (KRmu, PsRmu, IRmu) contained many of the same mycorrhizal and saprophytic species as did mature mesic and dryish heath forests (VMT and EVT). The fertile spruce mires group (RhK, MK) contained mostly saprophytic species, many of them also being common in mesic (VMT) and rich (GOMT) heath forests.

The mycorrhizal species compositions of virgin spruce mires, pine bogs and fens differ distinctly from one another, owing to differences in tree, shrub and dwarf shrub species composition: They also differ with regard to saprophytic species; because of their richer surface vegetation, spruce mires have more plant material to be decomposed. The results of the present study also indicate the significance of intermediate peatland site types from the standpoint of the macrofungi: Spruce-pine mire (KR) sample plots are characterised by the fact 
that they contain species of both spruce mires and pine bogs.

In the classification of macrofungi, it is necessary to realise that fungi are not as firmly fixed to their substrate as plants are. The fact that fungi are attached to trees, shrubs and dwarf shrubs, litter, humus, mosses and peat makes it more difficult to interpret a particular species of fungus as a member of the mycocommunity. The occurrence of fungi is subject to succession similar to that of plants. Different species dominate in the development classes of stands of the various forest types. Closing of the canopy is followed by the appearance of new species of fungus, along with changes in tree species and surface vegetation species composition. The downweighting option used in DCA analysis improved the interpretability of fungus species in certain cases by reducing the significance of rarer species. A particular fungus species may occur on a sample plot by chance, and in doing so it can cause an error in the ordination, or a sample plot may move towards another group. In the present study, a typical "chance fungus" was Stropharia semiglobata; it can grow in hare droppings on any sample plot visited by hares.

The classification method employed made it possible to distinguish clear groups among the sample plots in forest and peatland site types. The sample plot group for forest site types also evidenced overlapping (Fig. 5). It was difficult to separate mycocommunities within vegetation types, owing to the gradual and multidimensional variation of mycocommunities. Forest types also tend not to be distinctly delimited in terms of their fertility gradient (e.g. dry and dryish heath forests; Kuusipalo 1985, Hotanen \& Nousiainen 1990). With the DCA results as the basis, the structure of mycocommunities can be described as to heath forest vegetation, for instance, by means of a one-dimensional moisture - fertility gradient even though the primary gradient is complex (Fig. 5).

Macrofungus communities have multi-dimensional (complex) structures and there is much room for variation, because many environmental factors (and perhaps the fungi themselves) influence the formation of fruit bodies. Factors influencing the structure of mycocommunities include tree species composition, stand age (development class) and canopy coverage, the physiological state of trees and fungal hyphae, precipitation and temperature during the growing season, the fertility of the substrate, moisture and dryness, the quantity and quality of plant species and of litter in field and ground layers, the thickness and moisture content of humus and moss layers, internal competition between fungus species, their ability to regulate spore production in favourable and unfavourable times, airborne pollutants, and soil acidity.

Acknowledgements: I wish to thank everyone who has taken part in this field study. I express my special gratitude to Juha-Pekka Hotanen and Hannu Nousiainen, my colleques. I shall never forget the days we spent together in the forests and peatlands of Karelia. Ms. Seija Sulonen provided technical assistance. The English language of the manuscript was translated and partly revised by Erkki Pekkinen, M.Sc. The manuscript was read and commented upon by Dr. Seppo Huhtinen, Prof. Teuvo Ahti, Dr. Yrjö Norokorpi, Dr. Pentti Sepponen and Juha-Pekka Hotanen, Lic. Ph. Once again, I extend my warmest thanks to the people mentioned above.

\section{References}

Ahti, T. 1981: Jäkälien määritysopas. - Helsingin yliop. kasvit. lait. monist. 71:1-79.

Ahti, T., Hämet-Ahti, L. \& Jalas, J. 1968: Vegetation zones and their sections in northwestern Europe. Ann. Bot. Fennici 5:169-211.

Arnolds, E. 1981: Ecology and coenology of macrofungi in grasslands and moist heathlands in Drenthe, the Netherlands. - Part I. Introduction and synecology. - Bibl. Mycol. 83:1-407.

Arnolds, E. 1985: De frequentie en geografische verspreiding van enkele macrofungi vroeger en nu. In: Arnolds, E. (ed.), Veranderingen in de paddestoelenflora (mycoflora). - Wet. Meded. K. N. N. V. 167:30-58.

Arnolds, E. 1988: The changing macromycete flora in the Netherlands. - Trans. British Mycol. Soc. 90:391406.

Arnolds, E. 1991: Decline of ectomycorrhizal fungi in Europe. - Agriculture, Ecosystems and Environment 35:209-244.

Barkman, J. J. 1976: Algemene inleiding tot de oecologie en sociologie van macrofungi. - Coolia 19:57-66.

Bills, G. F., Holtzman, G. I. \& Miller, O. K. 1986: Comparison of ectomycorrhizal — basidiomycete communities in red spruce versus northern hardwood forest of West Virginia. - Can. J. Bot. 64:760-768.

Blaschke, A. 1988: Mycorrhizal infection and changes in fine-root development of Norway spruce influenced by acid rain in the field. In: Jansen, A. E., Dighton, J. \& Bresser, A. H. M. (eds.), Ectomycorrhiza and Acid Rain. - Proc. Workshop/Expert Meeting Berg en Dal 1987:112-115.

van Breemen, N. \& van Dijk, H. F. G. 1988: Ecosystem effects of atmospheric deposition of nitrogen in the Netherlands. - Environ. Pollut. 54:249-274. 
Breitenbach, J. \& Kränzlin, F. 1981: Pilze der Schweiz. Band 1. Ascomyceten (Schlauchpilze). - 313 pp. Verlag Mykologia, Luzern.

Brown, A. C. \& Sinclair, W. A. 1981: Colonization and infection of primary roots of Douglas-fir seedlings by the ectomycorrhizal fungus Laccaria laccata. - For. Sci. 27:111-124.

Castello, J. D., Shaw, C. G. \& Furniss, M. M. 1976: Isolation of Cryptoporus volvatus and Fomes pinicola from Dendroctonus pseudotsugae. - Phytopathology 66:1431-1434.

Cooke, R. C. \& Rayner, A. D. M. 1984: Ecology of saprotrophic fungi. $-415 \mathrm{pp}$. London.

Dahlberg, A. 1991: Ectomycorrhiza in coniferous forest: structure and dynamics of populations and communities. Swedish Univ. Agricultural Sciences, Dept. Forest Mycology and Pathology. Uppsala. - 38 pp.

Dahlberg, A. \& Stenlid, J. 1990: Population structure and dynamics in Suillus bovinus as indicated by spatial distribution of fungal clones. - New Phytol. 115:487-493.

Dahlberg, A. \& Stenström, E. 1991: Dynamic changes in nursery and indigenous mycorrhiza of Pinus sylvestris seedlings planted out in forest and clearcut. - Plant and Soil 136:73-86.

Darimont, F. 1973: Researches mycosociologiques dans les forêts de Haute Belgique I-II. - In: Mém. Inst. Royal Sci. Nat. Belgique 170:1-220.

Dennis, R. W. G. 1978: British Ascomycetes. - 585 pp. A. R. Ganther Verlag K. G., Vaduz.

De Dominicis, V. \& Barluzzi, C. 1983: Coenological research on macrofungi in evergreen oak woods in the hills near Sienne (Italy) - Vegetatio 54:177-187.

Dighton, J. A. \& Skeffington, R. A. 1987: Effects of artificial acid precipitation on the mycorrhizas of Scots pine seedlings. — New Phytol. 107:191-202.

Dighton, J. \& Harrison, A. F. 1990: Changes in phosphate status of Sitka spruce plantations of increesing age, as determined by root bioassays. For. Ecol. Manage. 31:35-44

Einhellinger, A. 1976: Die Pilze in primären und sekundären Pflanzengesellschaften oberbayerischer Moore. 1. - Ber. Bayer. Bot. Ges. 47:75-149.

Einhellinger, A. 1977: Die Pilze in primären und sekundären Pflanzengesellschaften oberbayerischer Moore. 2. - Ber. Bayer. Bot. Ges. 48:61-146.

Einhellinger, A. 1982: Das Murnauer Moor und seine Pilze. - Hoppea 41:347-398.

Favre, J. 1948: Les associations fongiques des hautsmarais jurassiens et de quelques régions voisines. Matér. Flore Cryptogam. Suisse 10:1-228.

Fellner, R. 1987: Principles of the arrangement of syntaxonomic classification of mycocoenoses. In: Pacioni, G. (ed.), Studies on fungal communities. Mycosociology or mycocoenology? - Problems and methods: $231-245$.

Fellner, R. 1988a: Poznámky k mykocenologické syntaxonomii. 2. Přehled syntaxonomické klasifikace mykocenóz respectující zásadu jednoty substrátu a trofismu. Summary: Notes to mycocoenological syntaxonomy. 2. The survey of the syntaxonomic classification of mycocoenoses taking into account the principle of the unity of the substratum and trophism. - Česká Mykol. 42:41-51.

Fellner, R. 1988b: Effects of acid deposition on the ectotrophic stability of mountain forest ecosystems in Central Europe (Czechoslovakia). In: Jansen, A. E., Dighton, J. \& Bresser, A. H. M. (eds.), Ectomycorrhiza and Acid Rain. - Proc. Workshop/ Expert Meeting Berg en Dal 1987:116-121.

Fellner, R. 1989: Mycorrhiza - forming fungi as bioindicators of air pollution. - Agriculture, Ecosystems and Environment 28:115-120.

Friedrich, K. 1936: Zur Ökologie der höheren Pilze 1. Ber. Deutschen Bot. Ges. 54:386-393.

Friedrich, K. 1937: Zur Ökologie der höheren Pilze 2. Ber. Deutschen Bot. Ges. 55:419-426.

Gulden, G. 1982: Soppsosiologi, en ny mykologisk forskningsretning i Norge. Summary: Mycosociology, a new branch of mycology in Norway. - Blyttia 40:95-99.

Gumińska, B. 1966: Mikroflora lasów jodowych okolic Muszyny. Summary: Mycoflora of the fir forests of Muszyna. - Acta Mycologica 2:107-149.

Haas, H. 1932: Die bodenbewohnenden Grosspilze in den Waldformationen einiger Gebiete von Württenberg. - Beih. z. Botan. Zentralbl. 50:35-134.

Hacskaylo, E. 1965: Telephora terrestris and mycorrhizae of Virgin pine. - For. Sci. 11:401-404.

Hansen, L. \& Knudsen, H. (eds.). 1992: Nordic Macromycetes. Vol. 2. Polyporales, Boletales, Agaricales, Russulales. - 474 pp. Helsinki.

Hansen, P. A. 1988: Prediction of macrofungal occurrence in Swedish beech forests from soil and litter variable models. - Vegetatio 78:31-44.

Hansen, P. A. 1989: Species response curves of macrofungi along a mull/mor gradient in Swedish beech forests. - Vegetatio 82:69-78.

Harmaja, H. \& Korhonen, M. 1991: Suomen ryhäkkäät (Cystoderma). Summary: The Finnish species of Cystoderma. - Sienilehti 43:47-58.

Heikkilä, H. \& Kallio, P. 1966: On the problem of subarctic basidiolichens I. - Rep. Kevo Subarctic Res. Station 3:48-74.

Heikurainen, L. 1986: Suo-opas. - 51 pp. Helsinki.

Heikurainen, L. \& Pakarinen, P. 1982: Mire vegetation and site types. In: Laine, J. (ed.), Peatlands and their utilization in Finland. - Finnish Peatland Society, pp. 14-23. Helsinki.

Heimala-Raimas, R. 1986: Sienisadosta ja sienilajistosta kolmella lannoitetulla suomuuttumalla Ilomantsin Ahvensalossa. - 120 pp. M.Sc. thesis, Univ. Joensuu.

Heiskanen, A. \& Ohenoja, E. 1986: Maassa kasvavat orakkaat Suomessa. Summary: Terrestial hydnaceous fungi in Finland. - Sienilehti 38:27-39.

Herva, P. \& Norokorpi, Y. 1983: Kivalon kokeilualueen sienisadoista ja -lajistosta vuosina 1981-1982. — Metsäntutkimuslaitoksen tiedonantoja 105:145-152.

Hill, M. O. 1979a: TWINSPAN — A FORTRAN program for arranging multivariate data in an ordered two-way table by classification of the individuals and attributes. - 48 pp. Cornell Univ., Ithaca, NY.

Hill, M. O. 1979b: DECORANA — A FORTRAN program for detrended correspondence analysis and reciprocal averaging. -52 pp. Cornell Univ., Ithaca, NY. 
Hill, M. O. \& Gauch, H. G. 1980: Detrended correspondence analysis: an improved ordination technique. - Vegetatio 42:47-58.

Hintikka, V. 1988: On the macromycete flora in oligotrophic pine forests of different ages in South Finland. - Acta Bot. Fennica 136:89-94.

Hintikka, V. \& Näykki, O. 1967: Notes on the effects of the fungus Hydnellum ferrugineum (Fr.) Karst. on forest soil and vegetation. - Commun. Inst. For. Fenniae 62:1-23.

Holownia, I. 1978: Wyniki badán nad produkeja owocników grzybów w ekosystemach lésnych rezerwatu "Las Piwnicki". Summary: Results of studies on the production of fungi fruit bodies in the forest ecosystems of the reserve "Las Piwnicki". - Acta Universitatis Nicolai Copernici, Biologia 21:61-73.

Hotanen, J.-P. \& Nousiainen, H. 1990: Metsä- ja suokasvillisuuden numeerisen ryhmittelyn ja kasvupaikkatyyppien rinnastettavuus. Summary: The parity between numerical unit and site types of forest and mire vegetation. - Folia For. 763:1-54.

Huikari, O., Muotiala, S. \& Wäre, M. 1964: Ojitusopas. 244 pp. Helsinki.

Huikari, O. 1974: Site quality estimation on forest land. In: Heikurainen, L. (ed.), Proc. Int. Symp. Forest Drainage, 2nd-6th September, 1974. — Jyväskylä-Oulu, Finland, pp. $15-24$.

Hämet-Ahti, L., Suominen, J., Ulvinen, T., Uotila, P. \& Vuokko, S. (eds.). 1986: Retkeilykasvio. - 598 pp. Suomen Luonnonsuojelun Tuki Oy. Helsinki.

Höfler, K. 1937: Pilzsoziologie. - Ber. Deutschen Bot. Ges. 55:606-622.

Jansen, A. E. 1981: The vegetation and macrofungi of acid oakwoods in the North East Netherlands. Doctoral Thesis - 132 pp. Univ. Wageningen.

Jansen, A. E. 1988: The influence of acid rain on mycorrhizal fungi and mycorrhizas of Douglas fir (Pseudotsuga menziesii) in the Netherlands. In: Mathy, P. (ed.), Air Pollution and Ecosystems. Proc. Int. Symp. Grenoble, France, 18-22 May 1987. - Reidel, Dordrecht, pp. 859-863.

Jansen, E. \& van Dobben, H. F. 1987: Is decline of Cantharellus cibarius in the Netherlands due to air pollution? - Ambio 16:211-213.

Jansen, A. E. \& De Nie, H. W. 1988: Relations between mycorrhizas and fruitbodies of mycorrhizal fungi in Douglas fir plantations in the Netherlands. - Acta Bot. Nederlandi 37:243-249.

Jansen, A. E. \& Dighton, J. 1990: Effects of air pollutants on ectomycorrhizas. A review. - Air Pollution Research Report 30:1-58.

Jülich, W. 1984: Die Nichtblätterpilze, Gallertpilze und Bauchpilze. (Aphyllophorales, Heterobasidiomycetes, Gastromycetes). In: Gams, H. (ed.), Kleine Kryptogamenflora 2b(1), Basidiomyceten 1. - 626 pp. Gustav Fischer Verlag, Stuttgart \& New York.

Jäppinen, J.-P., Hotanen, J.-P. \& Salo, K. 1986: Marja- ja sienisadot ja niiden suhde metsikkötunnuksiin mustikka- ja puolukkatyypin kankailla Ilomantsissa vuosina 1982-1984. Summary: Yields of wild berries and larger fungi and their relationship to stand characteristics on MT and VT-type mineral soil sites in Ilomantsi, Eastern Finland, 1982-1984. — Folia For. 670:1-25.
Kalamees, K. 1968: Mycocoenological methods based on investigations in the Estonian forests. - Acta Mycologica 4:327-335.

Kalamees, K. 1971: Some methodological aspects of mycocoenology. - Estonian Contr. Internat. Biol. Program (IBP) 2:33-46.

Kalamees, K. 1979: The role of fungal groupings in the structure of ecosystems. Eesti NSV Teaduste Akadeemia Toimetised (Biologia) 28:206-213.

Kalamees, K. 1980a: The composition and seasonal dynamics of the fungal cover on mineral soils. Scripta Mycol. 9:5-70.

Kalamees, K. 1980b: Trophic groups of Estonian agarics. - Scripta Mycol. 9:71-98.

Kalamees, K. 1982: The composition and seasonal dynamics of fungal cover on peat soils. In: Peatland ecosystems. Researches into the plant cover of Estonian bogs and their productivity. - $164 \mathrm{pp}$. Tallinn.

Kalamees, K. \& Raitviir, A. 1982: A list of higher fungi of Estonian peatlands. In: Peatland ecosystems. Researches into the plant cover of Estonian bogs and their productivity. - $164 \mathrm{pp}$. Tallinn.

Kalliola, R. 1973: Suomen kasvimaantiede. - 308 pp. Werner Söderström Oy, Porvoo - Helsinki.

Kardell, L. 1984: Skogsgödslingens inverkan på bär och matsvampar. - Skogsfakta 5:67-73.

Kardell, L. \& Eriksson, C. 1987: Kremlor, riskor, roppar. Skogsbruksmetodernas inverkan på produktionen av matsvampar. - Sveriges Skogsvårdsforbunds Tidskr. 2:3-23.

Kardell, L., Persson, O., Carlsson, E. \& Eriksson, L. 1980: Skogsmarkens produktion av marksvampar. Svensk Bot. Tidskr. 74:91-102.

Kauppila, P. \& Niemelä, T. 1986: Nahakkamaisia lahopuitten sieniä. Summary: Some stereoid woodrotting fungi in Finland. - Sienilehti 38:5-20.

Kolkki, O. 1966: Taulukoita ja karttoja Suomen lämpötilasta kaudelta 1931-1960. Summary: Tables and maps of temperature in Finland during 1931-1960. Supplement to the Meteorological Yearbook of Finland 65(1a): 1-42.

Koponen, T. Isoviita, P. \& Lammes, T. 1977: The bryophytes of Finland: An annotated checklist. Flora Fennica 6:1-77.

Korhonen, K. 1978: Interfertility and clonal size in the Armillariella mellea complex. - Karstenia 18:31-42.

Kotlaba, F. \& Kubìčka, J. 1960: Die Mykoflora des Moores "Rotes Moos" bei Schalmanowitz in ihrer Beziehung zur Mykoflora der südbömischen Torfgebiete. - Česká Mykol. 14:90-100.

Kreisel, H. 1954: Beobachtungen über die Pilzflora einiger Hoch- und Zwischenmoore Ost-Meclenburgs. Wiss. Zeitschr. Univ. Greifswald 3:291-300.

Kristoffersen, S. 1981: Økologiske og sosiologiske unders $\varnothing$ kelser av storsopp i edelløvskogsbestand i Holtnesdalen, Hurum. I oreskogstypene: Alno (incanae)-Fraxinetum og Carici (elongatae)-Alnetum (glutinosae). Cand. real. Thesis. - 132 pp. Univ. Oslo (upubl.).

Kuusipalo, J. 1985: An ecological study of upland forest site classification in southern Finland. - Acta Forest. Fennica 192:1-78. 
Lahti, T. \& Väisänen, R. A. 1987: Ecological gradients of boreal forests in South Finland: an ordination test of Cajander's forest site type theory. - Vegetatio 68:145-156.

Lange, M. 1948: The agarics of Maglemose. A study in the ecology of the agarics, - Dansk Bot. Ark. 13:1-141.

Lehto, J. \& Leikola, M. 1987: Käytännön metsätyypit. — 98 pp. Helsinki.

Leischner-Siska, E. 1939: Zur Soziologie und Ökologie der höheren Pilze. — Beih. Bot. Zentralbl. (B) 59:360_ 429.

Lisiewska, M. 1965: Udział Grzybów wyzszych w gr dach Wielkopolski. Summary: Higher fungi of the Querco-Carpinetum of the Wielkopolska province. Acta Mycologica 1:169-271.

Lisiewska, M. 1974: Macromycetes of beech forests within the eastern part of the Fagus area in Europe. Acta Mycologica 10:3-72.

Lisiewska, M. 1978: Macromycetes na tle zespołów leśnych Swi tokrzyskiego Parku Narodowego. Summary: Macromycetes in forest associations of the Swi tokrzyski National Park. - Acta Mycologica 14:163-191.

Maas Geesteranus, R. A. 1975: Die terrestrischen Stachelpilze Europas. — Verh. Konigl. Nederl. Akad. Wetensch. Afd. Natuurk. 65:1-160.

Markussen, J. 1982: Sosiologiske og økologiske undersøkelser av storsopper i edelløvskogsreservat, Holtnesdalen, Hurum. (Melico-Piceetum coryletosum, Equiseto-Fraxinetum piceetosum, Ulmo-Tilietum lathyrietosum verni, Ulmo-Tilietum prunetosum padi). Cand. real. Thesis. $-156 \mathrm{pp}$. Univ. Oslo, (upubl.).

Mehus, H. 1986: Fruit body production of macrofungi in some North Norwegian forest types. Nordic J. Bot. 6:679-702.

Metsänheimo, K. 1982: Luoteis-Lapin syyssienisadosta ja -lajistosta vuosina 1976-78. — 97 pp. M.Sc. Thesis, Dept. Bot., Univ. Oulu.

Metsänheimo, K. 1987: Sociology and ecology of larger fungi in the subarctic and oroarctic zones in Northwest Finnish Lapland. In: Laursen, G. A., Ammirati, J. F. \& Redhead, S. A. (eds.), Arctic and Alpine Mycology II, pp. 61-69.

Meyer, F. H. 1987: Das Würzelsystem geschädigter Waldbestände. - Allg. Forst Zeitschr. 27-29:754757.

Nantel, P. \& Neumann, P. 1992: Ecology of ectomycorrhizal- basidiomycete communities on a local vegetation gradient. - Ecology 73:99-117.

Niemelä, T. 1988: Suomen kääpien määritysopas. - Helsingin yliop. kasvit. lait. monist. 110:1-96. Helsinki.

Nilsson, S. T. \& Bergkvist, B. 1983: Aluminium chemistry and acidification processes in a shallow podsol on the Swedish west coast. - Water, Air, Soil Poll. 20:311-329.

Ohenoja, E. 1993: Effect of weather conditions on the larger fungi at different forest sites in northern Finland in 1976-1988. - Acta Univ. Oul. A 243:1-69.

Ohenoja, E. \& Koistinen, R. 1984: Fruit body production of larger fungi in Finland. 2. Edible fungi in northern Finland 1976-1978. - Ann. Bot. Fennici 21:357366.
Oksanen, J. 1984: Lichen-rich forests and related communities in Finland: ordination and classification studies. Univ. Joensuu. - Publications in Sciences $1: 1-35$.

Økland, R. H. 1990: Vegetation ecology: theory, methods and applications with reference to Fennoscandia. Sommerfeltia supplement 1:1-233.

Østmoe, K. H. 1979: Økologiske og sosiologiske undersøkelser av storsopper i barskogssamfunn i Ås (Cladonio-Pinetum, Eu-Piceetum myrtilletosum, Melico-Piceetum typicum og Eu-Piceetum athyrietosum). Cand. real. Thesis. - 161 pp. Univ. Oslo, (upubl.).

Petrenko, I. A. 1978: Makro- i mikromitsety lesov Jakutii. - 134 pp. Nauka, Sibirskoe otdelenie. Novosibirsk.

Pohjois-Karjalan luonnonympäristö. 1974: PohjoisKarjalan seutukaavaliiton julkaisuja A10:1-64.

Rautavaara, T. 1947: Suomen sienisato. Summary: Studies on the mushroom crop in Finland and its utilization. — 534 pp. Werner Söderström Osakeyhtiö, Porvoo \& Helsinki.

Redheard, S. A. 1981: Parasitism of bryophytes by agarics. - Can. J. Bot. 59:63-67.

Saari, V. \& Salonen, V. 1983: Luonnontilaisten suotyyppien sienisadoista Korpilahden Ristisuolla vuosina 1981 ja 1982. — Metsäntutkimuslaitoksen tiedonantoja 91:11-20.

Salo, K. 1979: Mushrooms and mushroom yield on transitional peatlands in Central Finland. - Ann. Bot. Fennici 16:181-192.

Salonen, V. \& Saari, V. 1990: Generic composition of macrofungus communities on virgin mire site types in Central Finland. - Ann. Bot. Fennici 27:33-38.

Sarasto, J. 1957: Metsän kasvattamiseksi ojitettujen soiden aluskasvillisuuden rakenteesta ja kehityksestä Suomen eteläpuoliskossa. Referat: Über Struktur und Entwicklung der Bodenwegetation aut für Walderziehung entwässerten Mooren in der südlichen Hälfte Finlands. - Acta Forest. Fennica 65:1-108.

Sarasto, J. 1961: Über die Klassifizierung für der Walderziehung entwässerten Moore. - Acta Forest. Fennica 74:1-57.

Sepponen, P. 1985: The ecological classification of sorted forest soils of varying genesis in northern Finland. Commun. Inst. For. Fenniae 129:1-77.

Sevola, J. 1983: Metsähallinnon Nurmeksen hoitoalueen voimaperäinen puunkasvatus: Seurantajärjestelmä ja tuloksia. Summary: Intensive timber growing in a state forest district: Monitoring system and results. — Folia For. 574:1-83.

Singer, S. B. 1980: DATAEDIT - A FORTRAN program for editing data matrices. $-43 \mathrm{pp}$. Cornell University, Ithaca, New York.

Sjöblom, M., Wessmann, L., Albrecht, A. \& Rancken, R. 1979: Svampproduktionen samt en jämförelse av virkes-, bär- och svampproduktionens värde i några skogar i Ekenästrakten 1976-1978. - 51 pp. Yrkesutbildningsstyrelsen. Avd. för forstundervisning. Helsingfors.

Strid, §. 1982: Svensk taggsvampar. I. Historik, definition och systematik. - Jordstjärnan 3:14-18.

Thesleff, A. 1920: Studier öfver basidsvampfloran i sydöstra Finland med hänsyn till dess samman- 
sättning, fysiognomi, fenologi och ekologi. - Bidr. Känned. Finlands Nat. Folk 79:1-140.

Tonteri, T., Mikkola, K. \& Lahti, T. 1990: Compositional gradients in the forest vegetation of Finland. - Journal of Vegetation Science 1:691-698.

Tortić, M. \& Lisiewska, M. 1978: Macromycetes in some chesnut forests in the vicinity of Zagreb. - Acta Bot. Croat. 37:189-201.

Trappe, J. M. 1962: Fungus associates of ectotrophic mycorrhizae. - Bot. Rev. 28:538-606.

Tuomikoski, R. 1960: Soiden lakkisienistä. — Suo 11:90 91.

Tyler, G. 1985: Macrofungal flora of Swedish beech forest related to soil organic matter and acidity characters. For. Ecol. Manag. 10:13-29.

Untiedt, E. \& Müller, K. 1985: Colonization of Sphagnum cells by Lyophyllum palustre. - Can. J. Bot. 63:757-761.

Vauras, J. \& Huhtinen, S. 1980: Turun Ruissalon metsäsienisadosta 1977-1978. - Sienilehti 32:22-27.

Veijalainen, H. 1974: Metsäojitusalueiden sienisadosta. Summary: Mushroom production on drained peatlands. - Suo 26:31-33.

Villeneuve, N., Grandtner, M. M. \& Fortin, J. A. 1989: Frequency and diversity of ectomycorrhizal and saprophytic macrofungi in the Laureentide Mountains of Quebec. - Can. J. Bot. 67:2616-2629.
Vogt, K. A., Edmonds, R. L., Grier, C. C. \& Diper, S. R. 1980: Seasonal changes in mykorrhizal and fibroustextured root biomass in 23 and 180 year old Pacific silver fir stands in Western Washington. - Can. J. For. Res. 10:523-529.

Vogt, K. A., Edmonds, R. L. \& Grier, C. C. 1981: Biomass and nutrient concentrations of sporocarps produced by mykorrhizal and decomposer fungi in Abies amabilis stands. - Oecologia 50:170-175.

Wilkins, W. H. \& Harris, G. C. M. 1946: The ecology of the larger fungi. V. An investigation into the influence of rainfall and temperature on the seasonal production of fungi in a beechwood and a pinewood. - Ann. of Appl. Biol. 33:179-188.

Winterhoff, W. (ed.) 1984: Vorläufige Rote Liste der Grosspilze (Makromyzeten). In: Blab, J., Nowak, E., Trautmann, W. \& Sukopp, H.: Rote Liste der gefährdete Tiere und Pflanzen in der Bundesrepublik Deutschland: 162-184.- Naturschutzaktuell.

Wästerlund \& Ingelög, T. 1981: Fruit body production of larger fungi in some young Swedish forests with special reference to logging waste. - For. Ecol. Manag. 3:269-294.

Received on 4 March 1993 


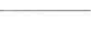

